University of Warwick institutional repository: http://go.warwick.ac.uk/wrap This paper is made available online in accordance with publisher policies. Please scroll down to view the document itself. Please refer to the repository record for this item and our policy information available from the repository home page for further information.

To see the final version of this paper please visit the publisher's website. Access to the published version may require a subscription.

Author(s): Foster C, Hillsdon M, Thorogood M

Article Title: Interventions for promoting physical activity (Review)

Year of publication: 2005

Link to published version:http://dx.doi.org/

10.1002/14651858.CD003180.pub2.

Publisher statement: None 


\title{
Interventions for promoting physical activity (Review)
}

\author{
Foster C, Hillsdon M, Thorogood M
}

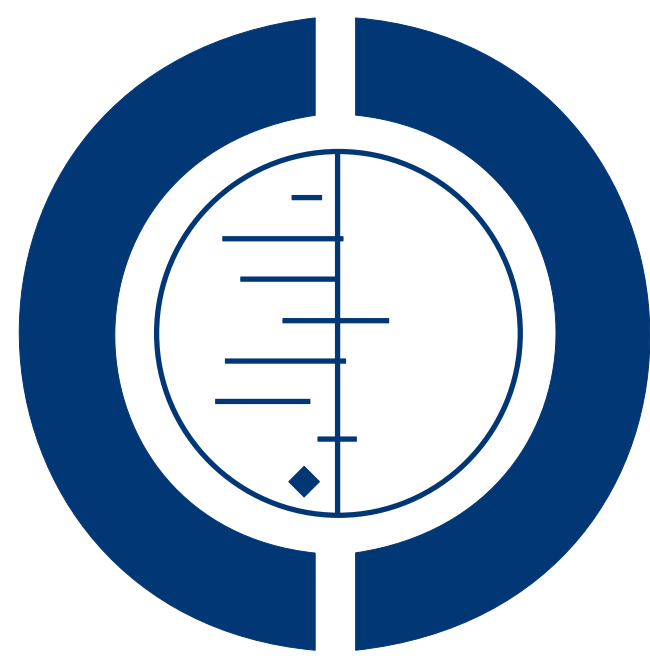

THE COCHRANE COLLABORATION $^{\circledR}$

This is a reprint of a Cochrane review, prepared and maintained by The Cochrane Collaboration and published in The Cochrane Library 2008, Issue 4

http://www.thecochranelibrary.com

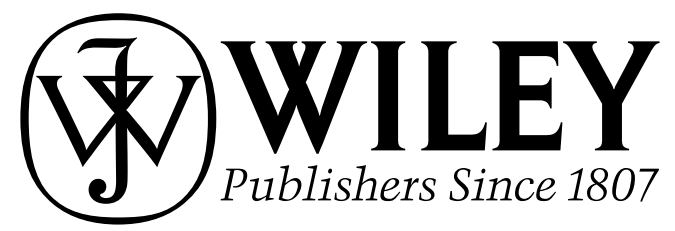

Interventions for promoting physical activity (Review)

Copyright $\odot 2008$ The Cochrane Collaboration. Published by John Wiley \& Sons, Ltd 
TABLE OF CONTENTS

ABSTRACT . . . . . . . . . . . . . . . . . . . . . . . . . . . . . . . .

PLAIN LANGUAGE SUMMARY . . . . . . . . . . . . . . . . . . . . . . . . . . . . . . . . . . . . . . . .

BACKGROUND . . . . . . . . . . . . . . . . . . . . . . . . . . . . . . . . . . . . . 2

OBJECTIVES . . . . . . . . . . . . . . . . . . . . . . . . . . . . . . . . . . . . . . . . . . . 2

CRITERIA FOR CONSIDERING STUDIES FOR THIS REVIEW . . . . . . . . . . . . . . . . . . . . . . . . . . .

SEARCH METHODS FOR IDENTIFICATION OF STUDIES . . . . . . . . . . . . . . . . . . . . . . . . . . . . 3

METHODS OF THE REVIEW . . . . . . . . . . . . . . . . . . . . . . . . . . . . . . . . . . . . . . . . . . . . . . c c 4

DESCRIPTION OF STUDIES . . . . . . . . . . . . . . . . . . . . . . . . . . . . . . . . . . . . . . . . . . . . . . .

METHODOLOGICAL QUALITY . . . . . . . . . . . . . . . . . . . . . . . . . . . . . . . . . . . . . . .

RESUlTS . . . . . . . . . . . . . . . . . . . . . . . . . . . . . . . . . . . . . . . . 6

DISCUSSION . . . . . . . . . . . . . . . . . . . . . . . . . . . . . . . . . . . . . . . . .

AUTHORS' CONCLUSIONS . . . . . . . . . . . . . . . . . . . . . . . . . . . . . . . . . . . . . . .

POTENTIAL CONFLICT OF INTEREST . . . . . . . . . . . . . . . . . . . . . . . . . . . . . . . . . . . . .

ACKNOWLEDGEMENTS . . . . . . . . . . . . . . . . . . . . . . . . . . . . . . . . . . . . . . . . . . . 11

SOURCES OF SUPPORT . . . . . . . . . . . . . . . . . . . . . . . . . . . . . . . . . . . . . 11

REFERENCES . . . . . . . . . . . . . . . . . . . . . . . . . . . . . . . . . . . . . . 11

TABLES . . . . . . . . . . . . . . . . . . . . . . . . . . . . . . . . . . . . . . . . .

Characteristics of included studies . . . . . . . . . . . . . . . . . . . . . . . . . . . . . . 22

Characteristics of excluded studies . . . . . . . . . . . . . . . . . . . . . . . . . . . . . . . . . . .

ADDITIONAL TABLES . . . . . . . . . . . . . . . . . . . . . . . . . . . . . . . . . . . . . 36

Table 01. Search Strategy for EMBASE $\quad . \quad$. . . . . . . . . . . . . . . . . . . . . . . . . . . . . . . . . . 36

Table 02. Search Strategy for CINAHL . . . . . . . . . . . . . . . . . . . . . . . . . . . . . . . . . $\quad$. 36

Table 03. Search Startegy for PsycLIT . . . . . . . . . . . . . . . . . . . . . . . . . . . . . . . . . $\quad$. 38

Table 04. Search Startegy SPORTSDISCUS . . . . . . . . . . . . . . . . . . . . . . . . . . . . . . . $\quad 39$

Table 05. Search Strategy SIGLE . . . . . . . . . . . . . . . . . . . . . . . . . . . . . . 40

Table 06. Search Strategy SCISEARCH . . . . . . . . . . . . . . . . . . . . . . . . . . . . . . . 40

Table 07. Descriptive data for review studies . . . . . . . . . . . . . . . . . . . . . . . . . . . . . . . 44

Table 08. Participation numbers in study recruitment, randomisation and follow up . . . . . . . . . . . . . . . . 43

Table 09. Characteristics of study type and intensity of intervention and follow up . . . . . . . . . . . . . . . . . 44

Table 10. Characteristics of study control groups and number of study arms . . . . . . . . . . . . . . . . . . . . 48

Table 11. Outcome measure, SMD, 95\% CI for studies with continuous self-reported PA . . . . . . . . . . . 50

Table 12. Outcome measure, OR, 95\% CI for studies with dichotomous physical activity . . . . . . . . . . . . 51

Table 13. Outcome measure, SMD, 95\% CI for studies with continuous cardio-respir fitness . . . . . . . . . . 53

ANALYSES . . . . . . . . . . . . . . . . . . . . . . . . . . . . . . . . . . . . . . . 53

Comparison 01. Pooled effects . . . . . . . . . . . . . . . . . . . . . . . . . . . . . . . . . . . 53

Comparison 02. Sensitivity anaylsis . . . . . . . . . . . . . . . . . . . . . . . . . . . . . . . . . . . . . 54

Comparison 03. Sub group analysis . . . . . . . . . . . . . . . . . . . . . . . . . . . . . . . . . . . 54

INDEX TERMS . . . . . . . . . . . . . . . . . . . . . . . . . . . . . . . . . . . . . . 54

COVER SHEET . . . . . . . . . . . . . . . . . . . . . . . . . . . . . . . . . . . . . . . . . . . 55

GRAPHS AND OTHER TABLES . . . . . . . . . . . . . . . . . . . . . . . . . . . . . . . . . . . . . . . . . 58

Figure 01. QUOROM statement . . . . . . . . . . . . . . . . . . . . . . . . . . . . . . . . . . . 58

Analysis 01.01. Comparison 01 Pooled effects, Outcome 01 Studies with continuous data for self-reported physical 59 activity

Analysis 01.02. Comparison 01 Pooled effects, Outcome 02 Studies with dichotomous data for self-reported physical 60 activity

Analysis 01.03. Comparison 01 Pooled effects, Outcome 03 Studies with continuous data for cardio-respiratory fitness

Analysis 02.01. Comparison 02 Sensitivity anaylsis, Outcome 01 Study quality - continuous data for self-reported physical activity

Analysis 02.02. Comparison 02 Sensitivity anaylsis, Outcome 02 Study quality - dichotomous data for self-reported physcial activity

Interventions for promoting physical activity (Review)

Copyright @ 2008 The Cochrane Collaboration. Published by John Wiley \& Sons, Ltd

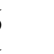

6

8

(

0

4

48

0

53

4

54

(3)

\section{.}


Analysis 02.03 . Comparison 02 Sensitivity anaylsis, Outcome 03 Study quality - continuous data for cardio-respiratory

fitness . . . . . . . . . . . . . . . . . . . . . . . . . . . . . . . . . . . .

Analysis 03.01. Comparison 03 Sub group analysis, Outcome 01 Nature of direction - self-reported physical activity

Analysis 03.02. Comparison 03 Sub group analysis, Outcome 02 Nature of direction - cardio-respiratory fitness . .

Analysis 03.03. Comparison 03 Sub group analysis, Outcome 03 Frequency of intervention occasions - self-reported physical activity

Analysis 03.04. Comparison 03 Sub group analysis, Outcome 04 Frequency of intervention occasions - dichotomous data . . . . . . . . . . . . . . . . . . . . . . . . . . . . . . . . . . . . . . .

Analysis 03.05. Comparison 03 Sub group analysis, Outcome 05 Frequency of intervention occasions - cardio-respiratory fitness

Analysis 03.06. Comparison 03 Sub group analysis, Outcome 06 Frequency of follow-up - self-reported physical activity Analysis 03.07. Comparison 03 Sub group analysis, Outcome 07 Frequency of follow-up - cardio-respiratory fitness . Analysis 03.08. Comparison 03 Sub group analysis, Outcome 08 Frequency of follow-up - dichotomous data . . . Analysis 03.09. Comparison 03 Sub group analysis, Outcome 09 Degree of supervision - self-reported physical activity Analysis 03.10. Comparison 03 Sub group analysis, Outcome 10 Degree of supervison - cardio-respiratory fitness 


\title{
Interventions for promoting physical activity (Review)
}

\author{
Foster C, Hillsdon M, Thorogood M
}

This record should be cited as:

Foster C, Hillsdon M, Thorogood M. Interventions for promoting physical activity. Cochrane Database of Systematic Reviews 2005, Issue 1. Art. No.: CD003180. DOI: 10.1002/14651858.CD003180.pub2.

This version first published online: 24 January 2005 in Issue 1, 2005.

Date of most recent substantive amendment: 26 April 2005

\begin{abstract}
A B S T R A C T
Background

Little is known about the effectiveness of strategies to enable people to achieve and maintain recommended levels of physical activity.
\end{abstract}

Objectives

To assess the effectiveness of interventions designed to promote physical activity in adults aged 16 years and older, not living in an institution.

\section{Search strategy}

We searched The Cochrane Library (issue 1 2005), MEDLINE, EMBASE, CINAHL, PsycLIT, BIDS ISI, SPORTDISCUS, SIGLE, SCISEARCH (from earliest dates available to December 2004). Reference lists of relevant articles were checked. No language restrictions were applied.

\section{Selection criteria}

Randomised controlled trials that compared different interventions to encourage sedentary adults not living in an institution to become physically active. Studies required a minimum of six months follow up from the start of the intervention to the collection of final data and either used an intention-to-treat analysis or, failing that, had no more than $20 \%$ loss to follow up.

\section{Data collection and analysis}

At least two reviewers independently assessed each study quality and extracted data. Study authors were contacted for additional information where necessary. Standardised mean differences and $95 \%$ confidence intervals were calculated for continuous measures of self-reported physical activity and cardio-respiratory fitness. For studies with dichotomous outcomes, odds ratios and $95 \%$ confidence intervals were calculated.

\section{Main results}

The effect of interventions on self-reported physical activity (19 studies; 7598 participants) was positive and moderate (pooled SMD random effects model $0.2895 \%$ CI 0.15 to 0.41 ) as was the effect of interventions (11 studies; 2195 participants) on cardio-respiratory fitness (pooled SMD random effects model $0.5295 \%$ CI 0.14 to 0.90 ). There was significant heterogeneity in the reported effects as well as heterogeneity in characteristics of the interventions. The heterogeneity in reported effects was reduced in higher quality studies, when physical activity was self-directed with some professional guidance and when there was on-going professional support.

\section{Authors' conclusions}

Our review suggests that physical activity interventions have a moderate effect on self-reported physical activity, on achieving a predetermined level of physical activity and cardio-respiratory fitness. Due to the clinical and statistical heterogeneity of the studies, only limited conclusions can be drawn about the effectiveness of individual components of the interventions. Future studies should provide greater detail of the components of interventions. 


\section{PLAIN LANGUAGE SUMMARY}

Not taking enough physical activity leads to an increased risk of a number of chronic diseases including coronary heart disease. Regular physical activity can reduce this risk and also provide other physical and possibly mental health benefits. The majority of adults are not active at recommended levels. The findings of this review indicate that professional advice and guidance with continued support can encourage people to be more physically active in the short to mid-term. More research is needed to establish which methods of exercise promotion work best in the long-term to encourage specific groups of people to be more physically active.

\section{B A C K G R O U N D}

Regular physical activity can play an important role both in the prevention and treatment of cardiovascular disease (CVD), hypertension, non-insulin dependent diabetes, diabetes mellitus, obesity, stroke, some cancers, and osteoporosis, as well as improve the lipid profile (DOH 2004; Folsom 1997; FNB 2002; US Dept. Health 1996; WHO 2004). A meta-analysis of the relationship between physical activity and coronary heart or cardiovascular disease reported a 30\% lower risk for the most physically active versus the least physically activity (Williams 2001). In addition, physical inactivity has been estimated to cause, globally, about $22 \%$ of ischaemic heart disease (WHO 2002).

The English Chief Medical Officer (CMO) advises that adults should undertake at least 30 minutes of 'moderate intensity' (5.0$7.5 \mathrm{kcal} / \mathrm{min}$ ) physical activity on at least 5 days of the week to benefit their health (DOH 2004). The recommendations are similar to those published in the US and by the World Health Organisation (Pate 1995; US Dept. Health 1996; WHO 2004).

In England the prevalence of physical activity at recommended levels is low. The most recent data show that only $37 \%$ of men and $25 \%$ of women meet the CMO's physical activity recommendation (DOH 2005a). Local government authorities have been set a target to 'increase the number of adults who engage in at least 30 minutes of moderate intensity level sport three times a week, by 3\% by 2008' (DOH 2005b; HM Treasury 2002).

There are randomised controlled trials assessing the effects of physical activity in the management of specific diseases, notably hypertension, hyperlipidaemia, obesity and CVD (DOH 2004). These show the effects of exercise on various physiological and biological outcomes and demonstrate the importance of exercise in the management of disease. However, because the main outcome of these trials is not physical activity, they do not help us understand the effectiveness of physical activity promotion strategies in the general population. A number of Cochrane reviews have assessed the relationship of the effects of exercise upon type 2 diabetes and as part of cardiac rehabilitation (Jolliffe 2001; Thomas 2006).

One recent published review examined the evidence for the effectiveness of 'home based' versus 'centre based' physical activity programs on the health of older adults (Ashworth 2005). Study participants had to have either a recognised cardiovascular risk factor, or existing cardiovascular disease, or chronic obstructive airways disease (COPD) or osteoarthritis. The authors found six trials involving 224 participants who received a 'home based' exercise program and 148 who received a 'centre based' exercise program. They concluded there was insufficient evidence to make any conclusions in support of either home or centre based physical activity programs.

\section{O B J E C T I VES}

To compare the effectiveness of interventions for physical activity promotion in adults aged 16 and above, not living in an institution, with no intervention, minimal intervention or attention control.

If sufficient trials existed, the following secondary objectives were to be explored:

a) Are more intense interventions more effective in changing physical activity than less intense interventions (e.g. a greater frequency and duration of professional contact and support $\mathrm{v}$ single contact)?

b) Are specific components of interventions associated with changes in physical activity behaviour (e.g. prescribed $\mathrm{v}$ self determined physical activity, supervised $\mathrm{v}$ unsupervised physical activity)?

c) Are short-term changes in physical activity or fitness (e.g. less than 3 months from intervention, less than 6 months from intervention) maintained at 12 months?

d) Is the promotion of some types of physical activity more likely to lead to change than other types of physical activity (e.g. walking versus exercise classes)?

e) Are home-based interventions more successful than facilitybased interventions?

f) Are interventions more successful with particular participant groups (e.g. women, older, minority)?

\section{CRITERIA FOR CONSIDERING STUDIES FOR THIS REVIEW}

\section{Types of studies}

Randomised controlled trials (RCTs) comparing different strate- 
gies to encourage sedentary, community dwelling adults to become more physically active, with a minimum of 6 months follow-up from the start of the intervention to the final results using either an intention to treat analysis or no more than $20 \%$ loss to follow up.

\section{Types of participants}

Community dwelling adults, age 16 years to any age, free from preexisting medical condition or with no more than $10 \%$ of subjects with pre-existing medical conditions that may limit participation in physical activity. Interventions on trained athletes or sports students were excluded.

\section{Types of intervention}

One only or a combination of:

- One-to-one counselling/advice or group counselling/advice;

- Self-directed or prescribed physical activity;

- Supervised or unsupervised physical activity;

- Home-based or facility-based physical activity;

- Ongoing face-to-face support;

- Telephone support;

- Written education/motivation support material;

- Self monitoring.

The interventions were conducted by one or a combination of practitioners including a physician, nurse, health educator, counsellor, exercise leader or peer. Mass media interventions and multiple risk factor interventions were excluded.

The interventions were compared with a no intervention control, attention control (receiving attention matched to length of intervention, e.g. general health check) and/or minimal intervention control group.

\section{Types of outcome measures}

\section{Primary outcome measures}

- Change in self-reported physical activity between baseline and follow-up.

- Cardio-respiratory fitness.

- Adverse events.

Physical activity measures were expressed as an estimate of total energy expenditure ( $\mathrm{kcal} / \mathrm{kg} /$ week, $\mathrm{kcal} /$ week), total minutes of physical activity, proportion reporting a pre-determined threshold level of physical activity (e.g., meeting current public health recommendation), frequency of participation in various types of physical activity e.g. walking, moderate intensity physical activity.

Cardio-respiratory fitness was either estimated from a sub-maximal fitness test or recorded directly from a maximal fitness test and was expressed as maximal oxygen consumption (VO2 max) either in $\mathrm{ml} \cdot \mathrm{kg}-1 \cdot \mathrm{min}-1$ or $\mathrm{ml} \cdot \mathrm{min}-1$. Aspects of cardio-respiratory fitness were also included as secondary outcome measures.

Adverse events included job-related injuries any reported musculoskeletal injury or cardiovascular events (and exercise-related cardiac events and injuries (fractures, sprains)).

\section{SEARCH METHODSFOR IDENTIFICATIONOF TUDIES}

See: Cochrane Heart Group methods used in reviews.

We searched The Cochrane Library (Issue 1, 2005) , MEDLINE (January 1966 to December 2004), EMBASE (January 1980 to December 2004), CINAHL (January 1982 to December 2004), PsycLIT (1887 to December 2004), BIDS ISI (January 1973 to December 2004), SPORTDISCUS (January 1980 to December 2004), SIGLE (January 1980 to December 2004) and SCISEARCH (January 1980 to December 2004), and reference lists of articles. Hand searching was conducted on one journal Medicine and Science in Sport and Exercise from 1990 to December 2004. Published systematic reviews of physical activity interventions were used as a source of randomised controlled trials. Reference lists of all relevant articles, books and personal contact with authors were also used. All languages were included.

The search strategy below was used to search MEDLINE, with the addition of an RCT filter (Dickersin 1995). This strategy was modified for other databases, using an appropriate RCT filter for EMBASE (Lefebvre 1996). (see Table 01 through to Table 06).

1 exp Exertion/

2 Physical fitness/

3 exp "Physical education and training"/

4 exp Sports/

5 exp Dancing/

6 exp Exercise therapy/

7 (physical\$ adj5 (fit\$ or train\$ or activ\$ or endur\$)).tw.

8 (exercis\$ adj5 (train\$ or physical\$ or activ\$)).tw.

9 sport\$.tw.

10 walk $\$$. tw.

11 bicycle $\$$.tw.

12 (exercise\$ adj aerobic\$).tw.

13 ("“lifestyle" or life-style) adj5 activ\$).tw.

14 (("lifestyle" or life-style) adj5 physical\$).tw.

15 or/ $1-14$

16 Health education/

17 Patient education/

18 Primary prevention/

19 Health promotion/

20 Behaviour therapy

21 Cognitive therapy

22 Primary health care 
23 Workplace/

24 promot\$.tw.

25 educat $\$$.tw.

26 program $\$$.tw.

27 or/ $16-26$

2815 and 27

\section{METHODSOF THEREVIEW}

All abstracts were reviewed independently by two investigators who applied the following criteria to determine if the full paper was needed for further investigation:

a) did the study aim to examine the effectiveness of a physical activity promotion strategy to increase physical activity behaviour? b) did the study have a control group (e.g. a no intervention control, attention control and/or minimal intervention control group)?

c) did the study allocate participants into intervention or control groups by a method of randomisation?

d) did the study include adults of 16 years or older?

e) did the study recruit adults not living in institutions and free of chronic disease?

f) was the study's main outcome physical activity or physical fitness?

g) were the main outcome(s) measured at least 6 months after the start of the intervention?

h) did the study analyse the results by intention-to-treat or, failing that was there less than $20 \%$ loss to follow up?

Two reviewers examined a hard copy of every paper that met the inclusion criteria on the basis of the abstract alone (or title and keywords if no abstract was available). When a final group of papers was identified all papers were reviewed again by two reviewers independently. Any disagreement at this stage was discussed between the three reviewers and resolved by consensus.

From the final set of studies that met the inclusion criteria, study details were extracted independently by two reviewers onto a standard form. Again any disagreements were discussed between three reviewers and resolved by consensus. Extracted data included date and location of study, study design variables, methodological quality, characteristics of participants (age, gender, ethnicity), intervention strategies, frequency and type of intervention and follow-up contacts, degree of physical activity supervision, study outcome measure, effectiveness of intervention and adverse events.

We wrote to and received clarification from 11 authors of the studies selected for the review. Our requests focused on data missing or unclear from the published papers and included data on study numbers at final analysis, means and standard deviations for intervention and control arms. For incomplete responses, we wrote again to authors asking for further data.
We found different types of outcome results published in two included papers for the Sendai Silver Centre Trial (SSCT 2000). Tsuji 2000 reported changes in cardiovascular fitness and Fujita 2003 reported increases in self-reported physical activity.

Outcomes were analysed both as continuous outcomes and as dichotomous outcomes (active/sedentary) wherever possible. Standard statistical approaches were adopted:

(a) For each study with continuous outcomes; a standardised mean difference (SMD) and 95\% confidence intervals (95\% CI) were calculated. If the study had more than two arms then the overall effects of the intervention versus control (means and standard deviations) were examined by pooling the individual effect of each intervention arm (means and standard deviations). These pooled groups means and standard deviations were weighted for overall numbers within each arm (Higgins 2005). Pooled effect sizes were calculated as standardised mean differences with 95\% CI using a random-effects model.

(b) For each study with dichotomous outcomes; an odds ratio (OR) and 95\% CI were calculated. Pooled effect sizes were calculated as ORs and with $95 \% \mathrm{CI}$ using a random-effects model.

We examined five thematic characteristics of each intervention to try to assess if they modified the main effects of the interventions. These five characteristics were the nature of direction at first contact, degree of programme supervision, frequency of intervention occasions, frequency of follow-up contacts and type of follow-up contacts.

We described the nature of the initial contact between the participant and professional/researcher as "the nature of direction". We found three types of intervention: (i) self-directed only - where the participant is not directed in their choices and thinking about which physical activities to start by the professional; (ii) selfdirected plus professional guidance - where the participant can make a decision about their physical activity using a mixture of both self direction and professional advice and guidance; and (iii) prescribed by professional only - the participant receives the advice and prescription of physical activity from the professional.

We wanted to evaluate the type and supervision of physical activity adopted within studies. We developed three categories of programme supervision: (i) structured and supervised - the physical activity programme was structured and supervised by professional; (ii) unsupervised and independent - the physical activity programme was unstructured and performed independently by the participant; and (iii) mixed - the physical activity programme was both structured and supervised and unstructured and independent.

\section{DESCRIPTION OF STUDIES}

From 35,524 hits, 287 papers were retrieved for examination 
against the inclusion criteria (Figure 01). Thirty three papers describing 35 studies met the inclusion criteria. We were unable to secure the requested information from five studies. Halbert 2000 was not contactable and so this study is not presented in the final results. Four studies sent data but the data was incomplete or inappropriate for meta-analysis (Castro 2001; Lowther 2002a; Lowther 2002b; Mutrie 2002; Nies 2003). After excluding these studies with incomplete data, 29 studies remained (Calfas 2000; Cunningham 1987; Dubbert 2002; Elley 2003; Goldstein 1999; Green 2002; Harland 1999; Hillsdon 2002; Inoue 2003; Juneau 1987; King 1988a; King 1988b; King 1991; Kriska 1986; Lamb 2002; Lombard 1995; Marshall 2003a; Marshall 2004; Norris 2000; Petrella 2003; Pinto 2002; Reid 1979; Resnick 2002a; Simons-Morton 2001a; Simons-Morton 2001b; Smith 2000; Stevens 1998; Stewart 2001; SSCT 2000). All 29 studies were randomised controlled trials. Two papers each reported the results of two separate trials (King 1988a; King 1988b; Simons-Morton 2001a; SimonsMorton 2001b). Two papers reported different outcomes for one study (SSCT 2000).

\section{Participants of included studies}

11,513 apparently healthy adults participated in the 29 included studies. The majority of studies recruited both genders with three studies recruiting men only (Cunningham 1987; Reid 1979; Simons-Morton 2001a) and four studies recruiting women only (Inoue 2003; Kriska 1986; Resnick 2002a; Simons-Morton 2001b). The stated age range of participants was from 18 to 95 years. Details on ethnic group of participants were reported in 13 studies, with proportions of participants in ethnic minorities ranging from $3 \%$ to $55 \%$. Participants were recruited from four settings; primary healthcare, workplaces, university and the community (see Table 07).

\section{Interventions in included studies}

We found a marked heterogeneity in the interventions used in each study. Studies used one, or combination of, one-to-one counselling/advice or group counselling/advice; self-directed or prescribed physical activity; supervised or unsupervised physical activity; home-based or facility-based physical activity; ongoing faceto-face support; telephone support; written education/motivation material; self monitoring. The intervention was delivered by one or a number of practitioners with various professional backgrounds including physicians, nurses, health educators, counsellors, exercise leaders and peers.

Only one study (SSCT 2000) adopted a structured and supervised approach to their intervention, encouraging participants to cycle on a static bike for 10 to 25 minutes at a pre-determined intensity, as part of a 2-hour exercise session. The majority of studies adopted an unstructured and independently performed physical activity regime.

We found the majority of studies contacted participants on at least three or more occasions in the first 4 weeks of the intervention to support and encourage any adoption of physical activity. Studies offered a range of support and follow up to participants between week 5 and final outcome measure (a minimum of 6 months post baseline intervention). The types of follow-up offered to participants at any point ranged from postal only, telephone only, faceto-face meetings, or a mixture of postal, telephone or face-to-face.

We found an even distribution of studies using all three approaches as described in our explanation of 'nature of direction' with the more recently published studies preferring self direction or self direction with professional guidance.

\section{Design of included studies}

Nine studies had a no-contact control group. Five studies had attention control groups with control participants receiving nonexercise related health advice. The remaining studies had comparison control groups, where participants received advice or written information about physical activity. In Petrella 2003 the control participants received exercise counselling and advice and were asked to keep a diary.

Eight studies had more than one intervention arm (Dubbert 2002; Harland 1999; Hillsdon 2002; King 1991; Norris 2000; SimonsMorton 2001a; Simons-Morton 2001b; Smith 2000). Four studies conducted an analysis of any intervention vs control by combining intervention arms (Harland 1999; Hillsdon 2002; Norris 2000; Smith 2000). We calculated pooled results for intervention arms for three further studies (King 1991; Simons-Morton 2001a; Simons-Morton 2001b). Our analysis of effectiveness when combining intervention arms, differed from the original results presented by two studies (King 1991; Simons-Morton 2001b). We also combined the results of two studies as the final results for control and intervention groups were reported separately by gender and there was no a priori hypothesis that the effect of the intervention would be different for men and women (Calfas 2000; Juneau 1987).

\section{Outcome measures}

A number of secondary outcome measures, which were not the focus of this review, were also measured and included body mass index (King 1991; Kriska 1986; Petrella 2003; Stewart 2001), health status, smoking status (King 1991; Kriska 1986; Norris 2000), socio-behavioural constructs (e.g. self efficacy, reduction in barriers to physical activity), social support and 'stage of change' (Calfas 2000; Goldstein 1999; Norris 2000), time spent in flexibility and strength training (Calfas 2000), weight, height, lean body mass, body fat, plasma lipids (Cunningham 1987; Juneau 1987; Kriska 1986), minute ventilation, maximal heart rate, respiratory exchange ratio, blood cholesterol, flexibility, grip strength, health conditions, systolic and diastolic blood pressure (Cunningham 1987; King 1991; Kriska 1986; Petrella 2003), and alcohol consumption (Kriska 1986). 


\section{METHODOLOGICAL QUALITY}

Two of the three reviewers independently assessed the quality of each study that met the inclusion criteria. We did not rate studies on whether participants were blind to their allocation to intervention or control groups. This would not be appropriate for studies of this type, as it would be impossible to blind participants to a physical activity intervention. Generation of a formal quality score for each study was completed on a four point scale assigning a value of 0 or 1 to each of the factors described below.

a) Was the randomisation method described?

All studies reported using randomisation to allocate participants to intervention and control groups, but only 16 described the method of randomisation. Of these, four studies used clusterrandomisation, where the unit of randomisation was participating practices (Norris 2000; Elley 2003), matched pairs of participating practices (Goldstein 1999), or workplace shifts (Reid 1979). One study used quasi-randomisation - days of the week (Smith 2000). All other studies randomised individuals.

b) Was the outcome assessment independent and blind? Twelve studies reported independent and blind outcome assessments (Dubbert 2002; Goldstein 1999; Green 2002; Harland 1999; Hillsdon 2002; King 1991; Marshall 2004; Petrella 2003; Pinto 2002; Simons-Morton 2001a; Simons-Morton 2001b; Smith 2000).

c) Was the final outcome measure controlled for baseline physical activity?

Sixteen studies reported adjusting their final results for baseline values of physical activity (Calfas 2000; Green 2002; Hillsdon 2002; Inoue 2003; King 1988a; King 1988b; King 1991; Lamb 2002; Marshall 2003a; Norris 2000; Petrella 2003; Pinto 2002; Simons-Morton 2001a; Simons-Morton 2001b; Smith 2000; Stewart 2001).

d) Was the analysis an intention-to-treat analysis?

Fourteen studies reported using an intention-to-treat analysis (Elley 2003; Hillsdon 2002; Kriska 1986; Lamb 2002; Lombard 1995; Marshall 2003a; Marshall 2004; Pinto 2002; Reid 1979; Simons-Morton 2001a; Simons-Morton 2001bSmith 2000; Stewart 2001; Stevens 1998). The remaining nine studies did not use an intention-to-treat analysis but had less than $20 \%$ loss to follow up. The proportion of participants in studies that did not perform an intention-to-treat analysis who were lost to follow up ranged from $0 \%$ to $18.9 \%$ (see Table 08 ).

Twenty-three studies reported data for the number of those participants who completed their study and the number of participants eligible for the study before randomisation. We calculated the proportion of the eligible participants who completed the study and this percentage ranged from $15.5 \%$ to $100 \%$. Table 08 presents the numbers of participants at different stages of each study. This data included the number of participants contacted to determine potential eligibility, number identified as eligible for study, number randomised, number with complete data at final outcome measure, number of participants with complete data at final outcome measure as a proportion of number identified as eligible for study and proportion of participants who were lost to follow-up.

Details of the intensity of the interventions studied, control interventions used and length of follow-up are in Table 09 and Table 10.

\section{R E S U L T S}

\section{Self-reported physical activity}

\section{Reported as a continuous measure}

Nineteen studies (7,598 participants) reported their main outcome as one of several continuous measures of physical activity (Calfas 2000; Cunningham 1987; Elley 2003; Goldstein 1999; Green 2002; Hillsdon 2002; Inoue 2003; King 1988a; King 1988b; Kriska 1986; Marshall 2003a; Pinto 2002; Resnick 2002a; Simons-Morton 2001a; Simons-Morton 2001b; Smith 2000; SSCT 2000; Stevens 1998; Stewart 2001). Measures included estimated energy expenditure (kcals/day, kcals/week of moderate physical activity), total time of physical activity (mean mins/week of moderate physical activity) and mean number of occasions of physical activity in past four weeks. The pooled effect of these studies was positive but moderate (SMD $0.28,95 \%$ CI 0.15 to 0.41 ) with significant heterogeneity in observed effects $\left(\mathrm{I}^{2}=83.5 \%\right)$. Seven studies reported positive effects (Cunningham 1987; Elley 2003; King 1988a; Kriska 1986; Stevens 1998; SSCT 2000; Stewart 2001) (see Table 11).

Studies with positive SMDs used a range of different intervention approaches with varying effect sizes. Kriska 1986 found that encouraging walking via an 8 -week training programme, followed by a choice of group or independent walking, plus follow-up phone calls and incentives resulted in a mean increase of $479 \mathrm{kcal} /$ week (95\% CI 249 to 708 ) of physical activity of all intensities. Cunningham 1987 found that encouragement to attend three group exercise sessions per week and perform an additional weekly exercise session at home resulted in an additional mean 53.7 minutes of vigorous physical activity per day (95\% CI 18.09 to 89.31 ).

King 1988a found a mean increase of 3.90 exercise sessions per month (95\% CI 0.43 to 7.37 ), at 6 months, following 30 minutes of baseline instruction ( 15 minutes of advice and a 15 minute video about exercise training), and daily self monitoring of physical activity using exercise logs returned to staff every month. These additional sessions were approximately equivalent to 101 minutes of moderate intensity physical activity per week. Stevens 1998 saw a net difference between intervention and control groups of 2.31 'sessions' (one session was at least 20 minutes of continuous physical activity) of moderate or vigorous exercise per month (95\% CI 1.91 to 2.71 ). At an initial meeting with a community exercise development officer intervention participants were encouraged to 
extend a physical activity that they already did rather than start a new activity. A further meeting was offered ten weeks later to support and encourage any changes. Stewart 2001 reported a significant net difference of $82 \mathrm{kcal}$ per day between the intervention and control arms (95\% CI 73.9 to 90.1). The intervention group received face-to-face counselling based on social cognitive theory (Bandura 1986). In addition they were offered further individual follow up appointments, educational materials, phone calls and monthly workshops about physical activity.

Elley 2003 reported a between group mean difference of 2.67 $\mathrm{kcal} / \mathrm{kg} / \mathrm{wk}$ (95\% CI 0.48 to 4.86 ). The authors estimate this was equivalent to a net difference of $247 \mathrm{kcals} /$ week between groups. The intervention group received motivational counselling from their general practitioner, followed by three follow up phone calls from a local exercise specialist, plus written materials. Participants were asked to choose their own physical activity.

SSCT 2000 reported a large increase in mean self-reported physical activity in their intervention group. However the physical activity regime was very prescriptive. Participants were encouraged to attend at least two from three 2-hour exercise classes per week, held at a local community centre. The class contained endurance and resistance training typically involving 10-25 minutes of static cycling at prescribed heart rate reserve, with intensity monitored by heart monitors. In addition to attending classes participants were asked to monitor their walking behaviour using pedometers.

No statistically significant effects were observed for the other 12 studies (Calfas 2000; Goldstein 1999; Green 2002; Hillsdon 2002; Inoue 2003; King 1988b; Marshall 2003a; Pinto 2002; Resnick 2002a; Simons-Morton 2001a; Simons-Morton 2001b; Smith 2000). No studies had effects that favoured controls.

\section{Reported as a dichotomous measure}

Ten studies (3595 participants) reported physical activity as a dichotomous measure which represented achievement or not of a predetermined level of physical activity (Dubbert 2002; Harland 1999; Lamb 2002; Lombard 1995; Marshall 2004; Norris 2000; Pinto 2002; Reid 1979; Simons-Morton 2001a; Simons-Morton 2001b). The pooled odds ratio of these studies was positive but modest (OR 1.33, 95\% CI 1.03 to 1.72 ) with significant heterogeneity in observed effects $\left(\mathrm{I}^{2}=53.4 \%\right)$. Only two studies reported a significantly positive effect (Dubbert 2002; Lombard 1995). Lombard 1995 found that participants who received a high frequency of follow up telephone calls (10 calls over 12 weeks) were more successful at changing their walking behaviour than participants who did not receive telephone calls (OR 10.95, 95\% CI 1.42 to 84.15 ). Dubbert 2002 found that adult participants who received a video, walking plan, weekly walking diary, financial incentive for completing diary, plus follow up phone calls were more successful at adhering to a 3 walks per week programme that participants who did not receive any phone calls (OR 2.31, 95\% CI 1.15 to 4.66 ) (see Table 12).
No effect was found in eight studies (Harland 1999; Lamb 2002; Marshall 2004; Norris 2000; Pinto 2002; Reid 1979; SimonsMorton 2001a; Simons-Morton 2001b). No studies had effects that favoured controls.

\section{Cardio-respiratory fitness}

In addition to self-reported physical activity, 11 studies (2195 participants) examined the effect of their intervention on cardio-respiratory fitness (Cunningham 1987; Dubbert 2002; Juneau 1987; King 1988a; King 1988b; King 1991; Lamb 2002; Petrella 2003; Simons-Morton 2001a; Simons-Morton 2001b; SSCT 2000) (see Table 13). The pooled effect was again positive and moderate with significant heterogeneity in the observed effects (SMD 0.52 95\% CI 0.14 to 0.90 ). Five studies (1359 participants) had significant positive effects that favoured treatment (Cunningham 1987; Juneau 1987; Petrella 2003; Simons-Morton 2001b; SSCT 2000). Cunningham 1987 reported that recently retired men who were offered supervised exercise sessions increased their fitness by a greater amount than controls who continued with their usual physical activity programmes (SMD $0.4495 \%$ CI 0.16 to 0.72 ). Juneau 1987 found a mean increase in fitness (SMD 1.49 95\% CI 1.07 to 1.91) for participants who received a combination of a 30-minute consultation, an educational video, information on using a heart rate monitor and a daily physical activity log, compared to controls. Simons-Morton 2001b found that women who received an intensive mixture of behavioural counselling, support materials and telephone calls (assistance + counselling arms) were more likely to increase their fitness (SMD 0.47, 95\% CI 0.23 to 0.71 ) than women who received a less intensive intervention (advice arm only). Petrella 2003 evaluated the effects of a fitness assessment using a step test and counselling from physician, plus a simple target heart rate goal and recording their physical activity in a diary on cardio-respiratory fitness. Controls received the same intervention without the heart rate goal setting. The standardised mean difference was 1.87 (95\% CI 1.59 to 2.15 ).

Although King 1991 reported a significant difference in VO2 max between intervention and control group at 12-months follow-up this difference did not remain when based on the standardised mean difference of the pooled intervention arms (SMD 0.17, 95\% CI -0.09 to 0.43 ). In one other study (King 1988b), the author reported a significant difference in the change in fitness between groups, which did not remain significant when based on standardised mean differences at 12 month follow up using their published data. This may be an effect of pooling study arms.

\section{Adverse events}

Eight studies reported data on adverse events. Only one study found a difference in the rate of adverse events between the intervention and control groups. Reid 1979 reported the rate of job-related injuries was four times higher in the control group compared to the intervention group. The other seven studies reported no significant difference in rates of musculoskeletal injury (fractures and sprains), falls, illness and potential cardiovascular events between 
groups (Dubbert 2002; Elley 2003; King 1991; Resnick 2002a; Simons-Morton 2001a; Simons-Morton 2001b; SSCT 2000).

\section{Sensitivity analysis by study quality}

We examined the pooled effects for the three types of outcome data (self-reported physical activity, dichotomous and cardio-respiratory fitness outcomes) by an assessment of study quality. High quality studies scored more than 2 on the quality scale. A score of 2 or less was categorised as low quality. For the 19 studies that reported continuous outcomes for physical activity six were classified as high quality (comparison 0201 ). The pooled effect of these interventions was again positive with no significant heterogeneity in the observed effects; the standardised mean difference was 0.11 ( $95 \%$ CI 0.04 to 0.17 ). Lower quality studies also had a positive pooled effect but with significant heterogeneity in the observed effects; the standardised mean difference was 0.36 (95\% CI 0.17 to 0.56 )

We found three high quality scoring studies from the 10 studies that reported dichotomous outcome data for self-reported physical activity (comparison 0202 ). The pooled odds ratio of these three studies was positive but modest (OR 1.48, 95\% CI 1.07 to 2.06 ) with no significant heterogeneity in observed effects.

We found five high quality studies from the 11 studies that reported continuous outcome data for cardio-respiratory fitness (comparison 02 03). The pooled effects of these studies was not significant and there was significant heterogeneity (SMD 0.54, 95\% CI -0.07 to 1.14 ). We noted two studies had a string effect on the pooled analysis (Juneau 1987; Petrella 2003).

\section{Secondary objectives}

a) Are more intense interventions more effective in changing physical activity than less intense interventions?

Two studies attempted to investigate the effect of increasing intervention intensity. In Simons-Morton 2001a and Simons-Morton $2001 \mathrm{~b}$ the three groups received different levels of intervention. The control group (advice) received physician advice to achieve the recommended level for exercise, then referral to an on-site health educator. At this appointment the health educator provided educational materials and repeated the physician advice to exercise with further follow-up appointments repeating this advice. No other follow-up activities were offered. The assistance group received the same advice from a physician and also received a 30-40 minute counselling session the health educator conducted, including a videotape and action planning. Participants then received followup phone calls, interactive mail, an electronic step counter, and monthly monitoring cards, which were returned to the health educator. Follow-up mail and incentives were sent to all participants. The counselling group received all of the components of the advice and assistance group with additional bi-weekly telephone calls for 6 weeks and then monthly telephone calls up to 12 months. Frequency of telephone calls for the final 12 months of the study was negotiated between the participant and their health educator.
Weekly behavioural classes on skills for adopting and maintaining physical activity were also offered to this group. In women, the addition of behavioural counselling, follow up support and materials produced a significant difference in fitness compared to the control groups. In men addition of these components did not lead to greater change (Simons-Morton 2001a and Simons-Morton 2001b).

\section{b) Are specific components of interventions associated with changes in physical activity behaviour?}

We stratified the behavioural components of the interventions, according to a number of characteristics. These characteristics were the degree of nature of direction (the extent to which physical activity was prescribed or self-directed) and the level of on-going professional support (frequency of follow up after week five of the study). Although there were insufficient studies to statistically test the difference in observed effects between these various study characteristics, the significant heterogeneity in reported effects was reduced when physical activity was self-directed with some professional guidance and when there was on-going professional support (in studies with continuous outcome measures for self-reported physical activity).

\section{c) Are short term changes in physical activity or fitness main- tained at 12 months?}

Six studies reported outcomes more than 6 months after the initial intervention (e.g. at least a measure of the primary outcome at 6 months and 12 months post intervention). In King $1991 \mathrm{im}$ provements in physical activity and cardio-respiratory fitness at 6 months were maintained at 12 months for cardio-respiratory fitness only. Simons-Morton 2001a and Simons-Morton 2001b presented data for cardio-respiratory fitness and self-reported physical activity at 6 and 24 months. All three study arms increased their cardio respiratory fitness and self reported levels of physical activity between baseline and 6 months. However there were no significant differences between groups. At 24 months there was a significant difference in VO2 max between participants who received assistance and counselling compared to the advice group for women only (Simons-Morton 2001b). Calfas 2000 reported outcomes at 12 and 24 months with no significant effect observed at either time points. Lamb 2002 reported no significant effect in the likelihood of increasing walking at 6 and 12 months. Petrella 2003 reported a significant increase in cardio-respiratory fitness at 6 months and this effect was further increased at 12 months.

\section{d) Is the promotion of some types of physical activity more likely} to lead to change than other types of physical activity?

We were unable to determine if any type of physical activity is more likely to be adopted than any other type of physical activity, (e.g. walking, jogging or running) as the studies were not designed to examine this question and as such generally did not report exactly what type of physical activity was performed.

e) Are home-based interventions more successful than facilitybased interventions? 
No study specifically examined this question. However King 1991 compared the difference in adherence to prescribed physical activity sessions between participants who were prescribed homebased versus facility-based exercise. A greater number of participants completed at least $75 \%$ of prescribed exercise sessions in both home-based arms compared to the facility-based arms $(\mathrm{P}<$ $0.05)$. This improved adherence to the home-based exercise sessions was not reflected in greater improvements in fitness.

\section{f) Are interventions more successful with particular participant groups?}

Nine studies examined the differential effects of the interventions within various sub-groups.

Eight studies looked at the effect of gender (Calfas 2000; Elley 2003; Juneau 1987; King 1991; Petrella 2003; Simons-Morton 2001a; Simons-Morton 2001b; Stewart 2001). Greater effects were seen for improvements in cardio-respiratory fitness for women as compared to men in King 1991 and Simons-Morton 2001a and Simons-Morton 2001b, while Juneau 1987 reported a greater increase in VO2 max in men than women. Elley 2003 reported greater increases in men compared to women in the intervention group in reported physical activity.

Two studies found no differential effects between high and low levels of baseline self-reported physical activity (Petrella 2003; Stewart 2001). No effects were seen for age (above or below 75 years) in Stewart 2001. The same study found a greater increase in physical activity for overweight participants (BMI more than 27.0), compared with participants who were not overweight (Stewart 2001). Petrella 2003 examined differential effects of their intervention in four sub groups (i) gender, (ii) age (above versus below 70 years), (iii) chronic health conditions (less than two reported health conditions versus more two or more health conditions) and (iv) BMI $(<27,27-31,>32 \mathrm{BMI})$. The intervention group showed a greater improvement in cardio-respiratory fitness compared to the control group, in a between group analysis regardless of gender, age, having more than 2 chronic health conditions and $\mathrm{BMI}>32$.

\section{I S C U S S I O N}

Our updated review suggests that physical activity interventions have a positive moderate sized effect on increasing self-reported physical activity and measured cardio-respiratory fitness, at least in the short to mid-term. Any conclusions drawn from this review require some caution given the significant heterogeneity in the observed effects. Despite the heterogeneity between the studies, there is some indication that a mixture of professional guidance and self direction plus on-going professional support leads to more consistent effect estimates. The long-term effectiveness of these interventions is not established as the majority of studies stopped after 12 months.
These conclusions differ from the findings of previous systematic reviews (Hillsdon 1996; Hillsdon 1999). Earlier reviews concluded that interventions that encouraged home-based activity were more effective than facility-based activity interventions. This review used more rigid inclusion criteria (for example outcome measures with at least 6 months follow-up) and subsequently excluded some studies included in these previous reviews. We were also able to collect unpublished data from study authors and this allowed us to perform a quantitative analysis using standardised mean differences for effects as opposed to just descriptions alone. The conclusions are similar to another published review (Hillsdon 2004). However this review was not a synthesis of primary studies but rather a synthesis of high-quality systematic reviews and metaanalyses of studies to increase physical activity among adults. It assessed studies in particular settings and found strong evidence of effectiveness of interventions within healthcare and community settings, particularly brief advice from a health professional, supported by written materials, which is likely to be effective in producing a modest, short-term (6-12 weeks) effect on physical activity (Hillsdon 2004).

The findings of this review are in contrast to the conclusions of a review produced by the Center for Disease Control (Kahn 2002). Kahn 2002 examined the effectiveness of individual-based behavioural interventions for the promotion of physical activity. The review calculated effects as the net percent change from baseline - the median change scores. In 10 studies (using continuous outcome measures of self-reported physical activity), the authors found a median net increase of $35.4 \%$ (interquartile range, $16.7 \%$ to $83.3 \%$ ). Ten studies measured change in the time spent in physical activity, with a net median increase of $64.3 \%$ (interquartile range, $1.2 \%$ to $85.5 \%$ ). Four studies measured change in $\mathrm{VO} 2 \mathrm{max}$ with a median increase of $6.3 \%$ (interquartile range, $5.1 \%$ to $9.8 \%)$. Overall the authors concluded that there was "good" evidence to suggest that this type of intervention was effective in increasing physical activity. However the authors included studies with shorter periods of follow up, non randomised studies (including uncontrolled before and after studies), and did not take account of loss to follow up. Only one study, King 1991, was shared by both reviews.

\section{Quality of the evidence}

The quality of the studies in this current review was limited by a lack of intention-to-treat analysis and failure to examine the interaction between baseline levels of physical activity and exposure to the intervention. Only six studies (Green 2002; Hillsdon 2002; Lamb 2002; Petrella 2003; Simons-Morton 2001a; Simons-Morton $2001 \mathrm{~b}$ ) achieved all of the quality criteria. The observed effects were smaller but more consistent in studies with higher quality scores.

\section{Internal validity}

We found three main weaknesses to the studies in terms of their internal validity. First, none of the studies were able to blind par- 
ticipants to their allocation to intervention at baseline. However this criterion is not appropriate to such studies. It is very difficult to blind a participant to their study group if exercise is the intervention. This element of quality is more appropriate to pharmaceutical interventions where blinding for both researchers and participants reduces the risk of selection bias. Second, studies failed to state their randomisation methods. And third, the studies did not use personnel to collect main outcome measures that were independent and blinded to group allocation.

Misclassification of physical activity also threatens internal validity of studies. The insensitivity of self-reported physical activity measures leads to less precision in its measurement and increases the variance in measures of behaviour. As intervention and control group participants completed the same self-report measure, any misclassification is likely to be non-differential leading to an attenuation of the effect of the intervention. This problem would not apply to measures of cardio-respiratory fitness.

\section{External validity}

Limitations in the external validity of the studies relate to recruitment and screening of participants and the generalisability of the interventions into everyday practice.

The majority of the studies in the review recruited volunteers, for example people replying to newspaper advertisements and the interventions may be less effective in non-volunteer populations recruited, for example, from primary care settings. Often participants had to agree to extensive screening prior to randomisation and, as a consequence, the people who finally participated in the study were likely to be highly motivated. Participants who were randomised in Project ACT (Simons-Morton 2001a; Simons-Morton 2001b) had already undergone three screening visits. Participants in other studies attended pre-study promotional events plus a baseline assessment (Stewart 2001) or attended two screening interviews (Inoue 2003). By contrast, only three studies, Stevens 1998, Hillsdon 2002 and Elley 2003, randomised all participants at the point of invitation to the study prior to them agreeing to participate. This method is called Zelen randomisation and is adopted to reduce non-consent rates (Zelen 1990).

The physicians in the studies based in a primary healthcare setting may have been more motivated to deliver the interventions than might be observed in a non-trial setting. We noted that studies described 'recruiting' participating practices and physicians and reported using financial incentives to physicians and practice staff during the time of the study.

We noted a large drop out of participants between the recruitment, eligibility screening and randomisation phases of studies (data presented in Table 08). This drop out would limit the possible effects of such interventions and the generalisability of the studies.

Many interventions provided components which would be difficult to deliver in usual practice as they would demand large resources. For example studies offered a choice of physical activities plus offered initial support in supervised programmes of physical activity, as well as letting participants choose to exercise independently of professional support.

Only four studies reported data at 2 years, with one study demonstrating maintenance of improvement in cardio-respiratory fitness (Simons-Morton 2001b). Evidence for the long-term effectiveness of interventions is urgently required.

The participants in the studies reviewed were generally white, well educated and middle aged and it is possible that the observed effects may be different in the wider population. There were no studies in this review that examined the effectiveness of interventions in minority groups of any kind.

\section{A U T ORS, CONCLUSIONS}

\section{Implications for practice}

There is some evidence to suggest that interventions designed to increase physical activity can lead to moderate short and midterm increases in physical activity, at least in middle age. Due to the clinical and statistical heterogeneity of the studies, only limited conclusions can be drawn about the effectiveness of individual components of the interventions. Nevertheless interventions which provide people with professional guidance about starting an exercise programme and then provide on going support may be more effective in encouraging the uptake of physical activity. There is no evidence that such interventions will reduce physical activity or cause other harm. There is only very limited evidence of the long-term effectiveness of interventions.

\section{Implications for research}

Existing evidence about the effectiveness of physical activity interventions for sedentary adults in the general population is limited by the recruitment of motivated volunteers, and the problems of measuring of physical activity using self report. No studies examined the effect of interventions on participants from varying socioeconomic or ethnic groups. There is also an urgent need for studies with cost-effectiveness data. In order to better understand the independent effect of individual programme components, longer studies with greater power are required. High quality studies are required with larger numbers, with a greater variety of participants, and with longer follow-up periods. In this review we have been able to describe the quantity of the interventions but were unable to describe the quality of the components of the interventions. Future reports of studies should provide greater detail on the nature of the professional who delivered the interventions, the theoretical basis of the intervention and how the theory was translated into practice. 


\section{POTENTIALCONFLICTOF I N T ER E S T}

The authors of this review are also authors of one of the included studies (Hillsdon 2002).

\section{ACKNOWLEDGEMENTS}

Stewart 2001 provided clarification regarding the means and standard deviations for the weekly caloric expenditure in all and moderate intensity physical activity at 12 months follow up.

Smith 2000 provided the mean change and standard deviation of the total minutes of activity for the three arms of the study at 7-8 months follow-up.

Norris 2000 was unable to provide the standard deviations for various physical activity outcomes.

Calfas 2000 confirmed the final numbers of participants at the 24month follow-up.

Simons-Morton 2001a and Simons-Morton 2001b provided the standard errors for the physical activity and $\mathrm{VO} 2$ max values for men and women in all three study arms at 6-, 12- and 24- months follow-up.

Dubbert 2002 confirmed the numbers of participants in each study arm at baseline, 6 months and 12 months.

Marshall 2003a confirmed the details of the means and standard deviations of total average physical activity time (hrs/wk) for both study arms at 6 months follow-up.

\section{SOURCES OF S UPORT}

\section{External sources of support}

- CF funded by British Heart Foundation Core Grant - 20062011 UK

- First Cochrane Review was funded by British Heart Foundation Project Grant - PG/2001089 UK

Internal sources of support

- No sources of support supplied

\section{R E F E R E N C E S}

\section{References to studies included in this review}

Calfas 2000 \{published data only\}

Calfas KJ, Sallis JF, Nichols JF, Sarkin JA, Johnson MF, Caparosa S, et al.Project GRAD: two-year outcomes of a randomized controlled physical activity intervention among young adults. Graduate Ready for Activity Daily. American Journal of Preventive Medicine 2000;18 (1):28-37. [MEDLINE: 2910].

Cunningham 1987 \{published data only\}

Cunningham DA, Rechnitzer PA, Howard JH, Donner AP. Exercise training of men at retirement: a clinical trial. Journal of Gerontology 1987;42(1):17-23. [MEDLINE: 28197].

Dubbert 2002 \{published and unpublished data\} Dubbert PM, Cooper KM, Kirchner KA, Meydrech EF, Bilbrew D. Effects of nurse counseling on walking for exercise in elderly primary care patients. Journals of Gerontology Series A-Biological Sciences \& Medical Sciences 2002;57(11):M733-40.

Elley 2003 \{published data only\}

Elley CR, Kerse N, Arroll B, Robinson E. Effectiveness of counselling patients on physical activity in general practice: cluster randomised controlled trial. BMJ 2003;326(7393):793-800.

Goldstein 1999 \{published data only\} Goldstein MG, Pinto BM, Marcus BH. Physician based physical activity counselling for middle aged and older adults: a randomised trial. Annals of Behavioral Medicine 1999;21:40-7. [MEDLINE: 28230].

Green 2002 \{published data only\}

Green B, McAffee T, Hindmarsh M, Madsen L, Caplow M, Buist D. Effectiveness of telephone support in increasing physical activity lev- els in primary care patients. American Journal of Preventive Medicine 2002;22(3):177-83.

Harland 1999 \{published data only\}

Harland J, White M, Drinkwater C, Chinn D, Farr L, Howel D. The Newcastle exercise project: a randomised controlled trial of methods to promote physical activity in primary care. BMJ 1999;319(7213): 828-32. [MEDLINE: 3343]

Hillsdon 2002 \{published data only\}

Hillsdon M, Thorogood M, White IR, Foster C. Advising people to take more exercise is ineffective: a randomised controlled trial of physical activity promotion in primary care. International Journal of Epidemiology 2002;31(4):808-15.

Inoue 2003 \{published data only\} Inoue S, Odagiri Y, Wakui S, Katoh R, Moriguchi T, Ohya Y, et al.Randomized controlled trial to evaluate the effect of a physical activity intervention program based on behavioural medicine. Journal of Tokyo Medical University 2003;61:154-65.

Juneau 1987 \{published data only\}

Juneau M, Rogers F, De Santos V, Yee M, Evans A, Bohn A, et al.Effectiveness of self-monitored, home-based, moderate-intensity exercise training in middle-aged men and women. American Journal of Cardiology 1987;60(1):66-70.

King 1988a \{published data only\}

King AC, Taylor CB, Haskell WL, DeBusk RF. Strategies for increasing early adherence to and long-term maintenance of home-based exercise training in healthy middle-aged men and women. American Journal of Cardiology 1988;61(8):628-32. [MEDLINE: 28216]. 
King 1988b \{published data only\}

King AC, Taylor CB, Haskell WL, DeBusk RF. Strategies for increasing early adherence to and long-term maintenance of home-based exercise training in healthy middle-aged men and women. American Journal of Cardiology 1988;61(8):628-32. [MEDLINE: 28216].

King 1991 \{published data only\}

King AC, Haskell WL, Taylor CB, Kraemer HC, DeBusk RF. Groupvs home-based exercise training in healthy older men and women. A community-based clinical trial. JAMA 1991;266(11):1535-42. [MEDLINE: 28206].

Kriska 1986 \{published data only\}

Kriska AM, Bayles C, Cauley JA, LaPorte RE, Sandler RB, Pambianco G. A randomized exercise trial in older women: increased activity over two years and the factors associated with compliance. Medicine \& Science in Sports \& Exercise 1986;18(5):557-62. [MEDLINE: 28207].

Lamb 2002 \{published data only\} Lamb SE, Bartlett HP, Ashley A, Bird W. Can lay-led walking programmes increase physical activity in middle aged adults? A randomised controlled trial. Journal of Epidemiology \& Community Health 2002;56:246-52.

Lombard 1995 \{published data only\} Lombard DN, Lombard TN, Winett RA. Walking to meet health guidelines: the effect of prompting frequency and prompt structure. Health Psychology 1995;14(2):164-70. [MEDLINE: 28185].

Marshall 2003a \{published and unpublished data\}

Marshall AL, Bauman AE, Owen N, Booth ML, Crawford D, Marcus $\mathrm{BH}$. Population-based randomized controlled trial of a stage-targeted physical activity intervention. Annals of Behavioral Medicine 2003; 25(3):194-202.

Marshall 2004 \{published data only\}

Marshall AL, Bauman AE, Owen N, Booth ML, Crawford D, Marcus BH. Reaching out to promote physical activity in Australia: a statewide randomized controlled trial of a stage-targeted intervention. American Journal of Health Promotion 2004;18:283-7.

Norris 2000 \{published data only\}

Norris SL, Grothaus LC, Buchner DM, Pratt M. Effectiveness of physician-based assessment and counseling for exercise in a staff model HMO. Preventive Medicine 2000;30(6):513-23. [MEDLINE: 468].

Petrella 2003 \{published data only\}

Petrella RJ, Koval JJ, Cunningham DA, Paterson DH. Can primary care doctors prescribe exercise to improve fitness? The step test exercise prescription (STEP) project. American Journal of Preventive Medicine 2003;24(4):316-22.

Pinto 2002 \{published data only\}

Pinto BM, Friedman R, Marcus BH, Kelley H, Tennstedt S, Gillman MW. Effects of a computer-based, telephone counseling system on physical activity. American Journal of Preventive Medicine 2002;23 (2):113-20

Reid 1979 \{published data only\} Reid EL, Morgan RW. Exercise prescription: a clinical trial. American Journal of Public Health 1979;69(6):591-5. [MEDLINE: 516].
Resnick 2002a \{published data only\}

Resnick B. Testing the effect of the WALC intervention on exercise adherence in older adults. Journal of Gerontological Nursing 2002;28 (6):40-9.

Simons-Morton 2001a \{published data only\} Simons-Morton DG, Blair SN, King AC, Morgan TM, Applegate WB, O' Toole M, et al.Effects of physical activity counseling in primary care: The Activity Counseling Trial: A randomized controlled trial. JAMA 2001;286(6):677-87. [MEDLINE: 7812].

\section{Simons-Morton 2001b \{published data only\}}

Simons-Morton DG, Blair SN, King AC, Morgan TM, Applegate WB, O' Toole M, et al.Effects of physical activity counseling in primary care: The Activity Counseling Trial: A randomized controlled trial. JAMA 2001;286(6):677-87.

Smith 2000 \{published data only\} Smith BJ, Bauman AE, Bull FC, Booth ML, Harris MF. Promoting physical activity in general practice: a controlled trial of written advice and information materials. British Journal of Sports Medicine 2000; 34(4):262-7. [MEDLINE: 427].

\section{SSCT 2000 \{published data only\}}

Fujita K, Nagatomi R, Hozawa A, Ohkubo T, Sato K, Anzai Y, et al.Effects of exercise training on physical activity in older people: a randomized controlled trial. Journal of Epidemiology 2003;13(2): $120-6$.

*Tsuji I, Tamagawa A, Nagatomi R, Irie N, Ohkubo T, Saito M, et al.Randomized controlled trial of exercise training for older people (Sendai Silver Center Trial; SSCT): study design and primary outcome. Journal of Epidemiology 2000;10(1):55-64. [MEDLINE: 2867].

Stevens 1998 \{published data only\}

Stevens W, Hillsdon M, Thorogood M, McArdle D. Cost-effectiveness of a primary care based physical activity intervention in 45-74 year old men and women: a randomised controlled trial. British Journal of Sports Medicine 1998;32(3):236-41. [MEDLINE: 3561].

Stewart 2001 \{published data only\} Stewart AL, Verboncoeur CJ, McLellan BY, Gillis DE, Rush S, Mills KM, et al.Physical activity outcomes of CHAMPS II: a physical activity promotion program for older adults. Journals of Gerontology Series A-Biological Sciences \& Medical Sciences 2001;56(8):M465-70. [MEDLINE: 114].

\section{References to studies excluded from this review \\ Andersen 1999}

Andersen RE, Wadden TA, Bartlett SJ, Zemel B, Verde TJ, Franckowiak SC. Effects of lifestyle activity vs structured aerobic exercise in obese women. JAMA 1999;281(4):335-40. [MEDLINE: 26884].

\section{Andersen 2002}

Andersen LB, Klausen K, Nisbeth O. One-year effect of health counseling on life style and risk factors of heart disease [Et ars effekt af sundhedsvejledning pa livsstil og risikofaktorer for hjertesygdom]. Ugeskrift for Laeger 2002;164(13):1814-8.

\section{Aoun 2002}

Aoun S, Johnson L. Men's health promotion by general practitioners in a workplace setting. Australian Journal of Rural Health 2002;10 (6):268-72 


\section{Asikainen 2002}

Asikainen TM, Miilunpalo S, Oja P, Rinne M, Pasanen M, Uusi-Rasi $\mathrm{R}$, et al.Randomised, controlled walking trials in postmenopausal women: the minimum dose to improve aerobic fitness?. British Journal of Sports Medicine 2002;36(3):189-94.

\section{Asikainen 2003}

Asikainen TM, Miilunpalo S, Kukkonen-Harjula K, Nenonen A, Pasanen M, Rinne M, et al. Walking trials in postmenopausal women: effect of low doses of exercise and exercise fractionization on coronary risk factors. Scandinavian Journal of Medicine \& Science in Sports 2003;13(5):284-92.

\section{Atienza 2001}

Atienza AA. Home-based physical activity programs for middle-aged and older adults: Summary of empirical research. Journal of Aging and Physical Activity 2001;9(Suppl):S38-58.

\section{Atlantis 2004}

Atlantis E, Chow CM, Kirby A, Singh MF. An effective exercisebased intervention for improving mental health and quality of life measures: a randomized controlled trial. Preventive Medicine 2004; 39(2):424-34

\section{Ballantyne 1978}

Ballantyne D, Clark A, Dyker GS, Gillis CR, Hawthorne VM, Henry DA, et al.Prescribing exercise for the healthy assessment of compliance and effects on plasma lipids and lipoproteins. Health Bulletin 1978;36(4):169-76. [MEDLINE: 27336].

\section{Baranowski 1990}

Baranowski T, Simons-Morton B, Hooks P, Henske J, Tiernan K, Dunn JK, et al.A center-based program for exercise change among black-American families. Health Educucation Quarterly 1990;17(2): 179-96. [MEDLINE: 1463].

Baranowski 2003

Baranowski T, Baranowski JC, Cullen KW, Thompson DI, Nicklas T, Zakeri IE, et al.The Fun, Food, and Fitness Project (FFFP): the Baylor GEMS pilot study. Ethnicity \& Disease 2003;13(1 Suppl 1): S30-9.

Barnett 2003

Barnett A, Smith B, Lord SR, Williams M, Baumand A. Communitybased group exercise improves balance and reduces falls in at-risk older people: a randomised controlled trial. Age and Ageing 2003;32 (4):407-14

\section{Bauman 2001}

Bauman AE, Bellew B, Owen N, Vita P. Impact of an Australian mass media campaign targeting physical activity in 1998. American Journal of Preventive Medicine 2001;21(1):41-7.

\section{Bell 2001}

Bell AC, Swinburn BA, Amosa H, Scragg RK. A nutrition and exercise intervention program for controlling weight in Samoan communities in New Zealand. International Journal of Obesity 2001;25 (6):920-27. [MEDLINE: 26633].

\section{Blair 1986}

Blair SN, Piserchia PV, Wilbur CS, Crowder JH. A public health intervention model for work-site health promotion. Impact on exercise and physical fitness in a health promotion plan after 24 months. JAMA 1986;255(7):921-26. [MEDLINE: 582].

\section{Blumenthal 2000}

Blumenthal JA, Sherwood A, Gullette ECD, Babyak M, Waugh R, Georgiades A, et al.Exercise and weight loss reduce blood pressure in men and women with mild hypertension: Effects on cardiovascular, metabolic, and hemodynamic functioning. Archives of Internal Medicine 2000;160(13):1947-58. [MEDLINE: 26732].

Bonet 2003

Bonet J, Coll R, Rocha E, Romero R. Supervised versus recommended physical exercise in hypertensive women. Is its recommendation enough?. Blood Pressure 2003;12(3):139-44.

\section{Brownson 2004}

Brownson RC, Baker EA, Boyd RL, Caito NM, Duggan K, Housemann RA, et al.A community-based approach to promoting walking in rural areas. American Journal of Preventive Medicine 2004;27(1): $1-34$.

\section{Buijis 2003}

Buijs R, Ross-Kerr J, Cousins SO, Wilson D. Promoting participation: evaluation of a health promotion program for low income seniors. Journal of Community Health Nursing 2003;20(2):93-107.

\section{Bull 1998}

Bull FC, Jamrozik K. Advice on exercise from a family physician can help sedentary patients to become active. American Journal of Preventive Medicine 1998;15(2):85-94.

\section{Burke 2003}

Burke V, Giangiulio N, Gillam HF, Beilin LJ, Houghton S. Physical activity and nutrition programs for couples: a randomized controlled trial. Journal of Clinical Epidemiology 2003;56(5):421-32.

\section{Calfas 2002}

Calfas KJ, Sallis JF, Zabinski MF, Wilfley DE, Rupp J, Prochaska $\mathrm{J}-\mathrm{J}$, et al.Preliminary evaluation of a multicomponent program for nutrition and physical activity change in primary care: PACE + for adults. Preventive Medicine 2002;34(2):153-61.

\section{Campbell 1985}

Campbell MJ, Browne D, Waters WE. Can general practitioners influence exercise habits? Controlled trial. British Medical Journal Clinical Research Ed 1985;290(6474):1044-6. [MEDLINE: 671].

\section{Cardinal 1996}

Cardinal BJ, Sachs ML. Effects of mail-mediated, stage-matched exercise behavior change strategies on female adults' leisure-time exercise behavior. Journal of Sports Medicine \& Physical Fitness 1996;36 (2):100-7. [MEDLINE: 2486].

\section{Carels 2004}

Carels RA, Darby LA, Cacciapaglia HM, Douglass OM. Reducing cardiovascular risk factors in postmenopausal women through a lifestyle change intervention. Journal of Women's Health 2004;13(4): $412-26$.

\section{Castro 2002}

Castro C, King A. Telephone-assisted counseling for physical activity. Exercise \& Sport Sciences Reviews 2002;30(2):64-8.

\section{Chang 2003}

Chang SF. Worksite health promotion - on the effects of an employee fitness program. Journal of Nursing Research 2003;11(3):412-26. 


\section{Clark 2003}

Clark DO, Stump TE, Damush TM. Outcomes of an exercise program for older women recruited through primary care. Journal of Aging and Health 2003;15(3):567-85.

\section{Coleman 1999}

Coleman KJ, Raynor HR, Mueller DM, Cerny FJ, Dorn JM, et al.Providing sedentary adults with choices for meeting their walking goals. Preventive Medicine 1999;28(5):510-9. [MEDLINE: 28203].

\section{Collins 2004}

Collins R, Lee RE, Albright CL, King AC. The effects of a course preparing low-income multiethnic women to be more physically active. Health Education \& Behavior 2004;31(1):47-64.

\section{Conn 2002}

Conn VS, Valentine JC, Cooper HM. Interventions to increase physical activity among aging adults: A meta-analysis. Annals of Behavioral Medicine 2002;24(3):190-200.

\section{Conn 2003}

Conn VS, Burks KJ, Minor MA, Mehr DR. Randomized trial of 2 interventions to increase older women's exercise. American Journal of Health Behavior 2003;27(4):380-8.

\section{Dallow 2003}

Dallow CB, Anderson J. Using self-efficacy and a transtheoretical model to develop a physical activity intervention for obese women. American Journal of Health Promotion 2003;17(6):373-81.

\section{De Jong 2004}

De Jong ORW, Hopman RM, Tak ECMP, Klazinga NS. An implementation study of two evidence-based exercise and health education programmes for older adults with osteoarthritis of the knee and hip. Health Education Research 2004;19(3):316-25.

\section{Donnelly 2000}

Donnelly JE, Jacobsen DJ, Heelan KS, Seip R, Smith S. The effects of 18 months of intermittent vs continuous exercise on aerobic capacity, body weight and composition, and metabolic fitness in previously sedentary, moderately obese females. International Journal of Obesity \& Related Metabolic Disorders 2000;24(5):566-72. [MEDLINE: 26747].

\section{Dunn 1997}

Dunn AL, Marcus BH, Kampert JB, Garcia ME, Kohl HW, Blair SN. Reduction in cardiovascular disease risk factors: 6-month results from Project Active. Preventive Medicine 1997;26(6):883-92. [MEDLINE: 2215].

\section{Dunn 1998}

Dunn AL, Garcia ME, Marcus BH, Kampert JB, Kohl-HW III, Blair SN. Six-month physical activity and fitness changes in Project Active, a randomized trial. Medicine \& Science in Sports \& Exercise 1998;30 (7):1076-83. [MEDLINE: 6616].

\section{DuVall 2004}

DuVall C, Dinger MK, Taylor EL, Bemben D. Minimal-contact physical activity interventions in women: a pilot study. American Journal of Health Behavior 2004;28(3):280-6.

\section{Eakin 2000}

Eakin EG, Glasgow RE, Riley KM. Review of primary care-based physical activity intervention studies: effectiveness and implications for practice and future research. Journal of Family Practice 2000;49 (2):158-68. [MEDLINE: 2890].

\section{Eaton 1998}

Eaton CB, Menard LM. A systematic review of physical activity promotion in primary care office settings. Britich Journal of Sports Medicine 1998;32(1):11-16. [MEDLINE: 3428].

\section{Ebrahim 1997}

Ebrahim S, Thompson PW, Baskaran V, Evans K. Randomized placebo-controlled trial of brisk walking in the prevention of postmenopausal osteoporosis. Age \& Ageing 1997;26(4):253-60. [MEDLINE: 28208].

\section{Ebrahim 1998}

Ebrahim S, Smith GD. Lowering blood pressure: a systematic review of sustained effects of non-pharmacological interventions. Journal of Public Health Medicine 1998;20(4):441-8. [MEDLINE: 26889].

\section{Elberson 2001}

Elberson KL, Daniels KK, Miller PM. Structured and nonstructured exercise in a corporate wellness program. A comparison of physiological outcomes. Outcomes Management for Nursing Practice 2001;5 (2):82-6.

\section{Elliot 2004}

Elliot DL, Goldberg L, Duncan TE, Kuehl KS, Moe EL, Breger RK, et al.The PHLAME firefighters' study: feasibility and findings. American Journal of Health Behavior 2004;28(1):13-23.

\section{Emmons 1999}

Emmons KM, Linnan LA, Shadel WG, Marcus B, Abrams DB. The Working Healthy Project: a worksite health-promotion trial targeting physical activity, diet, and smoking. Journal of Occupational and Environmental Medicine 1999;41(7):545-55. [MEDLINE: 3177].

\section{Eriksen 2002}

Eriksen HR, Ihlebaek C, Mikkelsen A, Gronningsaeter H, Sandal GM, Ursin H. Improving subjective health at the worksite: a randomized controlled trial of stress management training, physical exercise and an integrated health programme. Occupational Medicine 2002;52(7):383-91.

\section{Fahrenwald 2002}

Fahrenwald NL, Sharma M. Development and expert evaluation of "Moms on the Move," a physical activity intervention for WIC mothers. Public Health Nursing 2002;19(6):423-39.

\section{Fiatarone 1994}

Fiatarone MA, O'Neill EF, Ryan ND, Clements KM, Solares GR, Nelson ME, et al.Exercise training and nutritional supplementation for physical frailty in very elderly people. New England Journal of Medicine 1994;330(25):1769-75. [MEDLINE: 28201].

\section{Focht 2004}

Focht BC, Brawley LR, Rejeski WJ, Ambrosius WT. Group-mediated activity counseling and traditional exercise therapy programs: Effects on health-related quality of life among older adults in cardiac rehabilitation. Annals of Behavioral Medicine 2004;28(1):52-61.

\section{Fody-Urias 2001}

Fody-Urias BM, Fillit H, Hill J. The effect of a fitness program on health status and health care consumption in Medicare MCOs. Managed Care Interface 2001;14(9):58-64. [MEDLINE: 38].

\section{Fritz 2001}

Fritz T, Rosenqvist U. Walking for exercise - immediate effect on blood glucose levels in type 2 diabetes. Scandian Journal of Primary Health Care 2001;19(1):31-3. 
Froehlich-Grobe 2004

Froehlich-Grobe K, White GW. Promoting physical activity among women with mobility impairments: A Randomized controlled trial to assess a home- and community-based intervention. Archives of Physical Medicine \& Rehabilitation 2004;85(4):640-8.

Furukawa 2003

Furukawa F, Kazuma K, Kawa M, Miyashita M, Niiro K, Kusukawa $\mathrm{R}$, et al.Effects of an off-site walking program on energy expenditure, serum lipids, and glucose metabolism in middle-aged women. Biological Research for Nursing 2003;4(3):181-92.

\section{Godin 1987}

Godin G, Desharnais R, Jobin J, Cook J. The impact of physical fitness and health-age appraisal upon exercise intentions and behavior. Journal of Behavioral Medicine 1987;10(3):241-50. [MEDLINE: 28221].

\section{Goldwater 1985}

Goldwater BC, Collis ML. Psychologic effects of cardiovascular conditioning: a controlled experiment. Psychosomatic Medicine 1985;47 (2):174-81. [MEDLINE: 28200].

\section{Gossard 1986}

Gossard D, Haskell WL, Taylor CB, Mueller JK, Rogers F, Chandler $\mathrm{M}$, et al.Effects of low- and high-intensity home-based exercise training on functional capacity in healthy middle-aged men. American Journal of Cardiology 1986;57(6):446-9. [MEDLINE: 28217].

\section{Graham-Clarke 1994}

Graham-Clarke P, Oldenburg B. The effectiveness of a general-practice-based physical activity intervention on patient physical activity status. Behaviour Change 1994;11(3):132-44. [MEDLINE: 28227].

\section{Granner 2001}

Granner ML, Liguori G, Kirkner GJ, Ainsworth BE. Health care provider counseling for physical activity among black and white South Carolinians. Journal of the South Carolina Medical Association 2001;97(8):338-41.

\section{Halbert 1999}

Halbert JA, Silagy CA, Finucane P, Withers RT, Hamdorf PA. Recruitment of older adults for a randomized, controlled trial of exercise advice in a general practice setting. Journal of the American Geriatrics Society 1999;47(4):477-81. [MEDLINE: 3066].

\section{Halbert 2000}

Halbert JA, Silagy CA, Finucane PM, Withers RT, Hamdorf PA. Physical activity and cardiovascular risk factors: effect of advice from an exercise specialist in Australian general practice. Medical Journal of Australia 2000;173(2):84-7.

\section{Halbert 2001}

Halbert J, Crotty M, Weller D, Ahern M, Silagy C. Primary carebased physical activity programs: Effectiveness in sedentary older patients with osteoarthritis symptoms. Arthritis \& Rheumism 2001;45 (3):228-34. [MEDLINE: 28087].

\section{Hamdorf 1999}

Hamdorf PA, Penhall RK. Walking with its training effects on the fitness and activity patterns of 79-91 year old females. Australian \& New Zealand Journal of Medicine 1999;29(1):22-8.

\section{Hamdorf 2002}

Hamdorf P, Starr G, Williams M. California Active Aging Project. Journal of Aging and Physical Activity 2002;10(3):354-9.

\section{Harrell 1996}

Harrell JS, Johnston LF, Griggs TR, Schaefer P, Carr-EG J, McMurray $\mathrm{RG}$, et al.An occupation based physical activity intervention program: improving fitness and decreasing obesity. AAOHNJ 1996;44 (8):377-84. [MEDLINE: 4736].

\section{Heinonen 1999}

Heinonen A, Kannus P, Sievanen H, Pasanen M, Oja P, Vuori I. Good maintenance of high-impact activity-induced bone gain by voluntary, unsupervised exercises: An 8-month follow-up of a randomized controlled trial. Journal of Bone \& Mineral Research 1999;14(1):1258. [MEDLINE: 3047].

\section{Hellenius 1995}

Hellenius ML, Brismar KE, Berglund BH, de Faire UH. Effects on glucose tolerance, insulin secretion, insulin-like growth factor 1 and its binding protein, IGFBP-1, in a randomized controlled diet and exercise study in healthy, middle-aged men. Journal of Internal Medicine 1995;238(2):121-30. [MEDLINE: 2681].

\section{Hellenius 1997}

Hellenius ML, Krakau I, Faire UD. Favourable long-term effects from advice on diet and exercise given to healthy men with raised cardiovascular risk factors. Nutrition Metabolism \& Cardiovascular Diseases 1997;7:294-300. [MEDLINE: 26966].

\section{Hirvensalo 2003}

Hirvensalo M, Heikkinen E, Lintunen T, Rantanen T. The effect of advice by health care professionals on increasing physical activity of older people. Scandinavian Journal of Medicine Science \& Sports 2003;13(4):231-6.

\section{Hopman-Rock 2002}

Hopman-Rock M, Westhoff MH. Health education and exercise stimulation for older people: development and evaluation of the program "Healthy and Vital" [Gezondheidsvoorlichting en bewegingsstimulering voor ouderen: ontwikkeling en evaluatie van het programma "Gezond \& Vitaal"]. Tijdschrift voor Gerontologie en Geriatrie 2002;33(2):56-63.

\section{Huang 2002}

Huang LH, Chen SW, Yu YP, Chen PR, Lin YC. The effectiveness of health promotion education programs for community elderly. Journal of Nursing Research 2002;10(4):261-70.

\section{Humpel 2004}

Humpel N, Marshall AL, Iverson D, Leslie E, Owen N. Trial of print and telephone delivered interventions to influence walking. Preventive Medicine 2004;39(3):635-41

\section{Jakicic 1995}

Jakicic JM, Wing RR, Butler BA, Robertson RJ. Prescribing exercise in multiple short bouts versus one continuous bout: effects on adherence, cardiorespiratory fitness, and weight loss in overweight women. International Journal of Obesity \& Related Metabolic Disorders 1995; 19(12):893-901. [MEDLINE: 28211].

\section{Jakicic 1999}

Jakicic JM, Winters C, Lang W, Wing RR. Effects of intermittent exercise and use of home exercise equipment on adherence, weight loss, and fitness in overweight women: a randomized trial. JAMA 1999;282(16):1554-60. [MEDLINE: 26796].

\section{Jette 1996}

Jette AM, Harris BA, Sleeper L, Lachman ME, Heislein D, Giorgetti $\mathrm{M}$, et al.A home-based exercise program for nondisabled older 
adults. Journal of the American Geriatrics Society 1996;44(6):644-9. [MEDLINE: 28186].

\section{Jobe 2001}

Jobe JB, Smith DM, Ball K, Tennstedt SL, Marsiske M, Willis SL. ACTIVE: a cognitive intervention trial to promote independence in older adults. Controlled Clinical Trials 2001;22(4):453-79.

\section{Kaukiainen 2002}

Kaukiainen A, Nygard CH, Virtanen P, Saloniemi A. Physical activity intervention among unemployed male construction workers. Advances in Physiotherapy 2002;4(1):1-15.

\section{Keele-Smith 2003}

Keele-Smith R, Leon T. Evaluation of individually tailored interventions on exercise adherence. Western Journal of Nursing Research 2003; 25(6):623-40

\section{Kelley 2004}

Kelley K, Abraham C. RCT of a theory-based intervention promoting healthy eating and physical activity amongst out-patients older than 65 years. Social Science \& Medicine 2004;59(4):787-97.

\section{Kennedy 2003}

Kennedy MF, Meeuwisse WH. Exercise counselling by family physicians in Canada. Preventive Medicine 2003;37(3):226-32.

\section{Kerr 2000}

Kerr J, McKenna J. A randomized control trial of new tailored walking campaigns in an employee sample. Journal of Health Communication 2000;5(3):265-79. [MEDLINE: 7929].

\section{Kim 2004}

Kim S, Koniak-Griffin D, Flaskerud JH, Guarnero PA. The impact of lay health advisors on cardiovascular health promotion: using a community-based participatory approach. Journal of Cardiovascular Nursing 2004;19(3):192-9.

\section{King 1984}

King AC, Frederiksen LW. Low-cost strategies for increasing exercise behaviour. Behavior Modification 1984;8(1):3-21. [MEDLINE: 28224]

\section{King 1995}

King AC, Haskell WL, Young DR, Oka RK, Stefanick ML. Longterm effects of varying intensities and formats of physical activity on participation rates, fitness, and lipoproteins in men and women aged 50 to 65 years. Circulation 1995;91(10):2596-604.

\section{King 1997}

King AC, Oman RF, Brassington GS, Bliwise DL, Haskell WL. Moderate-intensity exercise and self-rated quality of sleep in older adults. A randomized controlled trial. JAMA 1997;277(1):32-7. [MEDLINE: 28199].

\section{King 2000}

King AC, Pruitt LA, Phillips W, Oka R, Rodenburg A, Haskell WL. Comparative effects of two physical activity programs on measured and perceived physical functioning and other health-related quality of life outcomes in older adults. Journals of Gerontology Series ABiological Sciences \& Medical Sciences 2000;55(2):M74-83.

\section{King 2001}

King AC. Interventions to promote physical activity by older adults. J Gerontol A Biol Sci Med Sci 2001;56:36-46.

\section{Kinion 1993}

Kinion ES, Christie N, Villella AM. Promoting activity in the elderly through interdisciplinary linkages. NursingConnections $1993 ; \mathbf{6}$ (3):19-26. [MEDLINE: 1897].

\section{Kirk 2001}

Kirk AF, Higgins LA, Hughes AR, Fisher BM, Mutrie N, Hillis S, et al.A randomized, controlled trial to study the effect of exercise consultation on the promotion of physical activity in people with Type 2 diabetes: a pilot study. Diabetic Medicine 2001;18(11):87782.

Kirk 2004

Kirk AF, Mutrie N, MacIntyre PD, Fisher MB. Promoting and maintaining physical activity in people with type 2 diabetes. American Journal of Preventive Medicine 2004;27(4):289-96.

\section{Kirk-Gardner 2003}

Kirk-Gardner R, Steven D. Hearts for Life: a community program on heart health promotion. Canadian Journal of Cardiovascular Nursing 2003;13(1):5-10.

\section{Koffman 2001}

Koffman DM, Bazzarre T, Mosca L, Redberg R, Schmid T, Wattigney WA. An evaluation of Choose to Move 1999: an American Heart Association physical activity program for women. Archives of Internal Medicine 2001;161(18):2193-9.

\section{Kohno 2002}

Kohno H, Egawa K, Oida Y, Nagamatsu T, Kitabatake Y, Maie $H$. Effect of functional fitness promotion program for communitydwelling elderly person using the transtheoretical model. Bulletin of the Physical Fitness Research Institute 2001;100:11-20.

\section{Kontulainen 2004}

Kontulainen S, Heinonen A, Kannus P, Pasanen M, Sievanen H, Vuori I. Former exercisers of an 18-month intervention display residual aBMD benefits compared with control women 3.5 years postintervention: a follow -up of a randomized controlled high-impact trial. Osteoporosis International 2004;15(3):248-51.

\section{Kukkonen-H 1998}

Kukkonen-Harjula K, Laukkanen R, Vuori I, Oja P, Pasanen M, Nenonen A, et al.Effects of walking training on health-related fitness in healthy middle-aged adults--a randomized controlled study. Scandinavian Journal of Medicine \& Science in Sports 1998;8(4):236-42. [MEDLINE: 3563].

Lansdown 2002

Lansdown R, Ledward A, Hall A, Issae W, Yona E, Matulu J. Physical activity intervention: A Transtheoretical Model-based intervention designed to help sedentary young adults become active. Health Educucation Research 2002;17(4):451-60.

\section{Lawlor 2001}

Lawlor DA, Hopker SW. The effectiveness of exercise as an intervention in the management of depression: systematic review and metaregression analysis of randomised controlled trials. BMJ 2001;322 (7289):763-7. [MEDLINE: 341].

\section{Leon 1996}

Leon AS, Casal D, Jacobs D, Jr. Effects of 2,000 kcal per week of walking and stair climbing on physical fitness and risk factors for coronary heart disease. Journal of Cardiopulmonary Rehabilitation 1996;16(3): 183-92. [MEDLINE: 28219]. 


\section{Lewis 1993a}

Lewis CE, Raczynski JM, Heath GW, Levinson R, Hilyer JC, Cutter GR. Promoting physical activity in low-income African-American communities: the PARR project. Ethnicity \& Disease 1993;3(2):10618. [MEDLINE: 1852].

\section{Lewis 1993b}

Lewis BS, Lynch WD. The effect of physician advice on exercise behavior. Preventive Medicine 1993;22 (1):110-21. [MEDLINE: 1950].

\section{Li 2001}

Li F, Harmer P, McAuley E, Duncan TE, Duncan SC, Chaumeton $\mathrm{N}$, et al.An evaluation of the effects of Tai Chi exercise on physical function among older persons: a randomized contolled trial. Annals of Behavioral Medicine 2001;23(2):139-46. [MEDLINE: 31].

\section{Lindstrom 2003}

Lindstrom J, Louheranta A, Mannelin M, Rastas M, Salminen V, Eriksson J. The Finnish Diabetes Prevention Study (DPS): Lifestyle intervention and 3 -year results on diet and physical activity. Diabetes Care 2003;26(12):3230-6.

\section{Little 2004}

Little P, Dorward M, Gralton S, Hammerton L, Pillinger J, White $\mathrm{P}$, et al.A randomised controlled trial of three pragmatic approaches to initiate increased physical activity in sedentary patients with risk factors for cardiovascular disease. British Journal of General Practice 2004;54(500):189-95.

\section{Lord 1995}

Lord JC, Green F. Exercise on prescription: does it work?. Health Educucation Journal 1995;54(4):453-64. [MEDLINE: 4685].

\section{Lupton 2002}

Lupton BS, Fonnebo V, Sogaard AJ, Langfeldt E. The Finnmark Intervention Study. Better health for the fishery population in an Arctic village in North Norway. Scandinavian Journal of Primary Health Care 2002;20(4):213-8.

\section{MacKeen 1985}

MacKeen PC, Rosenberger G, Slater JS, Nicholas WC, Buskirk ER. A 13-year follow-up of a coronary heart disease risk factor screening and exercise program for 40- to 59-year-old men: exercise habit maintenance and physiologic status. Journal of Cardiopulmonary Rehabilitation 1985;5(11):510-23.

\section{Manson 1999}

Manson JE, Hu FB, Rich-Edwards JW, Colditz GA, Stampfer MJ, Willett WC, et al.A prospective study of walking as compared with vigorous exercise in the prevention of coronary heart disease in women. New England Journal of Medicine 1999;341(9):650-8. [MEDLINE: 28223].

\section{Marcus 1992}

Marcus BH, Banspach SW, Lefebvre RC, Rossi JS, Carleton RA, et al.Using the stages of change model to increase the adoption of physical activity among community participants. American Journal of Health Promotion 1992;6(6):424-9. [MEDLINE: 1286].

\section{Marcus 1993}

Marcus BH, Stanton AL. Evaluation of relapse prevention and reinforcement interventions to promote exercise adherence in sedentary females. Research Quarterly for Exercise \& Sport 1993;64(4):447-52. [MEDLINE: 28218].

\section{Marcus 1995}

Marcus BH, Albrecht AE, Niaura RS, Taylor ER, Simkin LR, Feder SI, et al.Exercise enhances the maintenance of smoking cessation in women. Addictive Behaviors 1995;20(1):87-92. [MEDLINE: 28198].

\section{Marcus 1998a}

Marcus BH, Emmons KM, Simkin-Silverman LR, Linnan LA, Taylor ER, Bock BC, et al.Evaluation of motivationally tailored vs. standard self-help physical activity interventions at the workplace. American Journal of Health Promotion 1998;12(4):246-53. [MEDLINE: 3694].

\section{Marcus 1998b}

Marcus BH, Bock BC, Pinto BM, Forsyth LH, Roberts MB, Traficante RM. Efficacy of an individualized, motivationally-tailored physical activity intervention. Annals of Behavioral Medicine 1998; 20:174-80.

\section{Marshall 2003b}

Marshall AL, Leslie ER, Bauman AE, Marcus BH, Owen N. Print versus website physical activity programs: a randomized trial. American Journal of Preventive Medicine 2003;25(2):88-94.

\section{Martin 2004}

Martin DE, Thuring N, Melges T, Martin BW. The Stages of Change in three stage concepts and two modes of physical activity: A comparison of stage distributions and practical implications. Health Education Research 2004;19(4):400-17.

\section{Mattila 2003}

Mattila R, Malmivaara A, Kastarinen M, Kivela SL, Nissinen A. Effectiveness of multidisciplinary lifestyle intervention for hypertension: a randomised controlled trial. Journal of Human Hypertension 2003;17(3):199-205.

\section{McAuley 1994}

McAuley E, Courneya KS, Rudolph DL, Lox CL. Enhancing exercise adherence in middle-aged males and females. Preventive Medicine 1994;23:498-506. [MEDLINE: 7484].

\section{McMahon 2002}

McMahon A, Kelleher CC, Helly G, Duffy E. Evaluation of a workplace cardiovascular health promotion programme in the Republic of Ireland. Health Promotion International 2002;17(4):297-308.

\section{McMurdo 1992}

McMurdo ME, Burnett L. Randomised controlled trial of exercise in the elderly. Gerontology 1992;38(5):292-8. [MEDLINE: 1237].

\section{McMurdo 1995}

McMurdo ME, Johnstone R. A randomized controlled trial of a home exercise programme for elderly people with poor mobility. Age \& Ageing 1995;24(5):425-8. [MEDLINE: 2774].

\section{Messier 2000}

Messier SP, Royer TD, Craven TE, O'Toole ML, Burns R, Ettinger WH. Long-term exercise and its effect on balance in older, osteoarthritic adults: results from the Fitness, Arthritis, and Seniors Trial (FAST). Journal of the American Geriatrics Society 2000;48(2): 131-8. [MEDLINE: 2870].

\section{Miller 2002}

Miller YD, Trost SG, Brown WJ. Mediators of physical activity behavior change among women with young children. American Journal of Preventive Medicine 2002;23(2 Suppl):98-103. 


\section{Mills 1996}

Mills KM, Stewart AL, King AC, Roitz K, Sepsis PG, Ritter PL, et al.Factors associated with enrollment of older adults into a physical activity promotion program. Journal of Aging \& Health 1996;8(1): 96-113. [MEDLINE: 2591].

\section{Milne 2002}

Milne S, Orbell S, Sheeran P. Combining motivational and volitional interventions to promote exercise participation: Protection motivation theory and implementation intentions. British Journal of Health Psychology 2002;7(2):163-84.

\section{Mulder 1981}

Mulder JA, Griffin R. Prescription of home exercise therapy for cardiovascular fitness. Journal of Family Practice 1981;13(3):345-8. [MEDLINE: 28196].

\section{Munsch 2003}

Munsch S, Biedert E, Keller U. Evaluation of a lifestyle change programme for the treatment of obesity in general practice. Swiss Medical Weekly 2003;133(9-10):148-54.

\section{Napolitano 2003}

Napolitano MA, Fotheringham M, Tate D, Sciamanna C, Leslie E, Owen $\mathrm{N}$, et al.Evaluation of an internet-based physical activity intervention: a preliminary investigation. Annals of Behavioral Medicine 2003;25(2):92-9.

\section{Naylor 1999}

Naylor PJ, Simmonds G, Riddoch C, Velleman G, Turton P. Comparison of stage-matched and unmatched interventions to promote exercise behaviour in the primary care setting. Health Education Research 1999;14(5):653-66. [MEDLINE: 3368].

\section{Newman 2002}

Newman CF. Effectiveness of physical activity interventions for older adults. American Journal of Preventive Medicine 2002;22(2):120-33.

\section{Nisbeth 2000}

Nisbeth O, Klausen K, Andersen LB. Effectiveness of counselling over 1 year on changes in lifestyle and coronary heart disease risk factors. Patient Education \& Counseling 2000;40(2):121-31. [MEDLINE: 264].

\section{Noland 1989}

Noland MP. The effects of self-monitoring and reinforcement on exercise adherence. Research Quarterly for Exercise \& Sport 1989;60 (3):216-24. [MEDLINE: 28220].

Nurminen 2002

Nurminen E, Malmivaara A, Ilmarinen J, Ylostalo P, Mutanen P, Ahonen G, et al.Effectiveness of a worksite exercise program with respect to perceived work ability and sick leaves among women with physical work. Scandinavian Journal of Work, Environment and Health 2002;28(2):85-93.

\section{Oexmann 2001}

Oexmann MJ, Ascanio R, Egan BM. Efficacy of a church-based intervention on cardiovascular risk reduction. Ethnicity \& Disease 2001; 11(4):817-22.

\section{Oida 2003}

Oida Y, Kitabatake Y, Nishijima Y, Nagamatsu T, Kohno H, Egawa $\mathrm{K}$. Effects of a 5-year exercise-centered health-promoting programme on mortality and ADL impairment in the elderly. Age \& Aging 2003; 32(6):585-92.

\section{Oman 2000}

Oman RF, King AC. The effect of life events and exercise program format on the adoption and maintenance of exercise behavior. Health Psychology 2000;19(6):605-12. [MEDLINE: 277].

\section{Ortega-Sanchez 2004}

Ortega-Sanchez R, Jimenez-Mena C, Cordoba-Garcia R, MunozLopez J, Garcia-Machado ML, Vilaseca-Canals J. The effect of officebased physician's advice on adolescent exercise behavior. Preventive Medicine 2004;38(2):219-26.

\section{Ostwald 1989}

Ostwald SK. Changing employees' dietary and exercise practices: an experimental study in a small company. Journal of Occupational Medicine 1989;31(2):90-7. [MEDLINE: 27197].

\section{Parks 1997}

Parks PSM, Read MH. Adolescent male athletes: Body image, diet, and exercise. Adolescence 1997;32(127):593-602. [MEDLINE: 7692].

\section{Partonen 1998}

Partonen T, Leppamaki S, Hurme J, Lonnqvist J. Randomized trial of physical exercise alone or combined with bright light on mood and health-related quality of life. Psychological Medicine 1998;28(6): 1359-64. [MEDLINE: 26897].

\section{Paschal 2004}

Paschal AM, Lewis RK, Martin A, Dennis-Shipp D, Simpson DS. Baseline assessment of the health status and health behaviors of African Americans participating in the activities-for-life program: a community -based health intervention program. Journal of Community Health 2004;29(4):305-18.

\section{Pereira 1998}

Pereira MA, Kriska AM, Day RD, Cauley JA, LaPorte RE, Kuller LH. A randomized walking trial in postmenopausal women: effects on physical activity and health 10 years later. Archives of Internal Medicine 1998;158(15):1695-701.

\section{Peterson 1999}

Peterson TR, Aldana SG. Improving exercise behavior: An application of the stages of change model in a worksite setting. American Journal of Health Promotion 1999;13(4):29-32. [MEDLINE: 7968].

\section{Peterson 2002}

Peterson J, Atwood JR, Yates B. Key elements for church-based health promotion programs: outcome-based literature review. Public Health Nursing 2002;19(6):401-11.

\section{Petrella 2000}

Petrella RJ, Wight D. An office-based instrument for exercise counseling and prescription in primary care. The Step Test Exercise Prescription (STEP). Archives of Family Medicine 2000;9(4):339-44. [MEDLINE: 2911].

\section{Petrella 2001}

Petrella RJ, Koval JJ, Cunningham DA, Paterson DH. A self-paced step test to predict aerobic fitness in older adults in the primary care clinic. Journal of the American Geriatrics Society 2001;49(5):632-8. [MEDLINE: 186].

\section{Pfeiffer 2001}

Pfeiffer BA, Clay SW, Conatser-RR J. A green prescription study: does written exercise prescribed by a physician result in increased 
physical activity among older adults?. Journal of Aging \& Health 2001; 13(4):527-38

Philips 2004

Phillips EM, Schneider JC, Mercer GR. Motivating elders to initiate and maintain exercise. Archives of Physical Medicine \& Rehabilitation 2004;85(7 Suppl 3):S52-7.

\section{Pinto 2001}

Pinto BM, Lynn H, Marcus BH, DePue J, Goldstein MG. Physicianbased activity counseling: intervention effects on mediators of motivational readiness for physical activity. Annals of Behavioral Medicine 2001;23(1):2-10. [MEDLINE: 195].

\section{Plotnikoff 2001}

Plotnikoff RC, Hotz SB, Birkett NJ, Courneya KS. Exercise and the transtheoretical model: a longitudinal test of a population sample. Prev Med 2001;33:441-52.

\section{Pohjonen 2001}

Pohjonen T, Ranta R. Effects of worksite physical exercise intervention on physical fitness, perceived health status, and work ability among home care workers: Five -year follow-up. Preventive Medicine 2001;32(6):465-75.

\section{Poole 2001}

Poole K, Kumpfer K, Pett M. The impact of an incentive-based worksite health promotion program on modifiable health risk factors. American Journal of Health Promotion 2001;16(1):21-6.

\section{Poston 2001}

Poston-WSC II, Haddock CK, Olvera NE, Suminski RR, Reeves RS, Dunn JK, et al.Evaluation of culturally appropriate intervention to increase physical activity. American Journal of Health Behavior 2001; 25(4):396-406

\section{Proper 2003a}

Proper KI, Hildebrandt VH, van der Beek AJ, Twisk JW, van Mechelen W. Effect of individual counseling on physical activity fitness and health: a randomized controlled trial in a workplace setting. American Journal of Preventive Medicine 2003;24(3):218-26.

\section{Proper 2003b}

Proper KI, Koning M, van der Beek AJ, Hildebrandt VH, Bosscher RJ, van Mechelen W. The effectiveness of worksite physical activity programs on physical activity, physical fitness, and health. Clinical Journal of Sport Medicine 2003;13(2):106-17.

\section{Purath 2004}

Purath J, Miller AM, McCabe G, Wilbur J. A brief intervention to increase physical activity in sedentary working women. Canadian Journal of Nursing Research 2004;36(1):76-91.

\section{Reijneveld 2003}

Reijneveld SA, Westhoff MH, Hopman-Rock M. Promotion of health and physical activity improves the mental health of elderly immigrants: results of a group randomised controlled trial among Turkish immigrants in the Netherlands aged 45 and over. Journal of Epidemiology \& Community Health 2003;57(6):405-11.

\section{Renger 2002}

Renger R, Steinfelt V, Lazarus S. Assessing the effectiveness of a community-based media campaign targeting physical inactivity. Family \& Community Health 2002;25(3):18-30.

\section{Resnick 2002b}

Resnick B, Magaziner J, Orwig D, Zimmerman S. Evaluating the components of the Exercise Plus Program: rationale, theory and implementation. Health Education Research 2002;17(5):648-58.

\section{Reynolds 2001}

Reynolds F. Strategies for facilitating physical activity and wellbeing: A health promotion perspective. British Journal of Occupational Therapy 2001;64(7):330-6.

\section{Robison 1992}

Robison JI, Rogers MA, Carlson JJ, Mavis BE. Effects of a 6-month incentive-based exercise program on adherence and work capacity. Medicine \& Science in Sports \& Exercise 1992;24(1):85-93. [MEDLINE: 7589].

\section{Ruby 1993}

Ruby KL, Blainey CA, Haas LB, Patrick M. The knowledge and practices of registered nurse, certified diabetes educators: teaching elderly clients about exercise. Diabetes Educator 1993;19(4):299-306. [MEDLINE: 1982].

\section{Samaras 1997}

Samaras K, Ashwell S, Mackintosh AM, Fleury AC, Campbell LV, Chisholm DJ. Will older sedentary people with non-insulin-dependent diabetes mellitus start exercising? A health promotion model. Diabetes Research \& Clinical Practice 1997;37(2):121-128. [MEDLINE: 2242].

\section{Schoenfelder 2000}

Schoenfelder DP. A fall prevention program for elderly individuals. Exercise in long-term care settings. Journal of Gerontological Nursing 2000;26(3):43-51. [MEDLINE: 348].

\section{Schuler 2002}

Schuler G. Primary and secondary prevention: physical activity [Primare und sekundare Pravention: Korperliche Aktivitat]. Zeitschrift fur Kardiologie 2002;91(Suppl 2):30-9.

\section{Sciamanna 2002}

Sciamanna CN, Lewis B, Tate D, Napolitano MA, Fotheringham $\mathrm{M}$, Marcus $\mathrm{BH}$. User attitudes toward a physical activity promotion website. Preventive Medicine 2002;35(6):612-5.

\section{Sevick 2000}

Sevick MA, Dunn AL, Morrow MS, Marcus BH, Chen GJ, Blair SN. Cost-effectiveness of lifestyle and structured exercise interventions in sedentary adults: Results of Project ACTIVE. American Journal of Preventive Medicine 2000;19(1):1-8. [MEDLINE: 7942].

\section{Simmons 2003}

Simmons D, Voyle JA. Reaching hard-to-reach, high-risk populations: piloting a health promotion and diabetes disease prevention programme on an urban marae in New Zealand. Health Promotion International 2003;18(1):41-50.

\section{Sims 2004}

Sims J, Huang N, Pietsch J, Naccarella L. The Victorian Active Script Programme: promising signs for general practitioners, population health, and the promotion of physical activity. British Journal of Sports Medicine 2004;38(1):19-25.

\section{Singh 1997}

Singh S. Why are GP exercise schemes so successful (for those who attend)? Results from a pilot study. Journal of Management in Medicine 1997;11(4):233-7. [MEDLINE: 2339]. 


\section{Singh 1997a}

Singh NA, Clements KM, Fiatarone MA. A randomized controlled trial of progressive resistance training in depressed elders. Journals of Gerontology Series A-Biological Sciences \& Medical Sciences 1997;52 (1):M27-35. [MEDLINE: 7698].

\section{Smith 2003}

Smith BJ, Brown BJ, Hermann JR. Impact of a physical activity program emphasizing cardiovascular fitness, muscle strength, and flexibility among middle-aged women. Journal of Nutrition Education \& Behavior 2003;35(4):215-216.

\section{Smolander 2000}

Smolander J, Blair SN, Kohl HW. Work ability, physical activity, and cardiorespiratory fitness: 2-year results from Project Active. Journal of Occupational \& Environmental Medicine 2000;42(9):906-10. [MEDLINE: 403].

\section{Sorensen 1999}

Sorensen M, Anderssen S, Hjerman I, Holme I, Ursin H. The effect of exercise and diet on mental health and quality of life in middleaged individuals with elevated risk factors for cardiovascular disease. Journal of Sports Sciences 1999;5(17):369-77. [MEDLINE: 26829].

Steptoe 1999

Steptoe A, Doherty S, Rink E, Kerry S, Kendrick T, Hilton S. Behavioural counselling in general practice for the promotion of healthy behaviour among adults at increased risk of coronary heart disease: randomized trial. BMJ 1999;319(7215):943-7. [MEDLINE: 26805].

Steptoe 2000

Steptoe A, Rink E, Kerry S. Psychosocial predictors of changes in physical activity in overweight sedentary adults following counseling in primary care. Preventive Medicine 2000;31(2 Pt 1):183-94. [MEDLINE: 3001].

\section{Steptoe 2001}

Steptoe A, Kerry S, Rink E, Hilton S. The impact of behavioral counseling on stage of change in fat intake, physical activity, and cigarette smoking in adults at increased risk of coronary heart disease. American Journal of Public Health 2001;91(2):265-9.

Stevens 1999

Stevens M, Bult P, de Greef MH, Lemmink KA, Rispens P. Groningen Active Living Model (GALM): stimulating physical activity in sedentary older adults. Preventive Medicine 1999;29(4):267-76. [MEDLINE: 3243].

Stevens 2003

Stevens M, Lemmink KA, van Heuvelen MJ, de Jong J, Rispens P. Groningen Active Living Model (GALM): stimulating physical activity in sedentary older adults; validation of the behavioral change model. Preventive Medicine 2003;37(6 Pt 1):561-70.

\section{Stiggelbout 2004}

Stiggelbout M, Popkema DY, Hopman-Rock M, de Greef M, van Mechelen W. Once a week is not enough: effects of a widely implemented group based exercise programme for older adults; a randomised controlled trial. Journal of Epidemiology \& Community Health 2004;58(2):83-8.

\section{Swinburn 2003}

Swinburn B, Sager R. Promotion of exercise prescriptions in general practice for older populations. Geriatrics and Aging 2003;6(7):2023.

\section{Taylor 1998}

Taylor AH, Doust J, Webborn N. Randomised controlled trial to examine the effects of a GP exercise referral programme in Hailsham, East Sussex, on modifiable coronary heart disease risk factors. Journal of Epidemiology \& Community Health 1998;52(9):595-601.

\section{Twisk 2004}

Twisk J, Proper K. Evaluation of the results of a randomized controlled trial: how to define changes between baseline and follow-up. Journal of Clinical Epidemiology 2004;57(3):223-8.

\section{van der Bij 2002}

van der Bij AK, Laurant M, Wensing M. Effectiveness of physical activity interventions for older adults: a review. American Journal of Preventive Medicine 2002;22(2):120-33.

\section{Veverka 2003}

Veverka D, Anderson J, Auld G, Coulter G, Kennedy C, Chapman P, et al.Use of the stages of change model in improving nutrition and exercise habits in enlisted Air Force men. Military Medicine 2003; 168(5):373-9.

\section{Votruba 1968}

Votruba SB, Horvitz MA, Schoeller DA. The role of exercise in the treatment of obesity. Nutrition 2000;16(3):179-88. [MEDLINE: 26749].

\section{Vuori 1994}

Vuori IM, Oja P, Paronen O. Physically active commuting to work-testing its potential for exercise promotion. Medicine \& Science in Sports \& Exercise 1994;26(7):844-50. [MEDLINE: 1719].

\section{Wankel 1985}

Wankel LM, Yardley JK, Graham J. The effects of motivational interventions upon the exercise adherence of high and low self-motivated adults. Canadian Journal of Applied Sport Sciences 1985;10(3): 147-56. [MEDLINE: 695].

\section{Weinehall 2001}

Weinehall L, Hellsten G, Boman K, Hallmans G. Prevention of cardiovascular disease in Sweden: the Norsjo community intervention programme--motives, methods and intervention components. Scandinavian Journal of Public Health. Supplement 2001;56:13-20.

\section{Wen 2002}

Wen LM, Thomas M, Jones H, Orr N, Moreton R, King L, et al.Promoting physical activity in women: evaluation of a 2-year community -based intervention in Sydney, Australia. Health Promotion International 2002;17(2):127-37.

\section{Wilbur 2001}

Wilbur J, Chandler P, Miller AM. Measuring adherence to a women's walking program. Western Journal of Nursing Research 2001;23(1): $8-24$.

\section{Wood 1983}

Wood PD, Haskell WL, Blair SN, Williams PT, Krauss RM, Lindgren FT, et al.Increased exercise level and plasma lipoprotein concentrations: a one-year, randomized, controlled study in sedentary, middle-aged men. Metabolism: Clinical \& Experimental 1983;32(1): 31-9. [MEDLINE: 28189].

\section{Woods 2002}

Woods C, Mutrie N, Scott M. Physical activity intervention: a transtheoretical model-based intervention designed to help sedentary 
young adults become active. Health Education Research 2002;17(4): 451-60.

Yalden 2001

Yalden J, Chung L. Tai Chi: towards an exercise program for the older person. Australian Journal of Holistic Nursing 2001;8(1):4-13.

Yanek 2001

Yanek LR, Becker DM, Moy TF, Gittelsohn J, Koffman DM. Project Joy: faith based cardiovascular health promotion for African American women. Public Health Reports 2001;116(Suppl 1):68-81.

Young 1999

Young DR, Appel LJ, Jee S, Miller ER 3rd. The effects of aerobic exercise and T'ai Chi on blood pressure in older people: results of a randomized trial. Journal of the American Geriatrics Society 1999;47 (3):277-284. [MEDLINE: 28222].

\section{Zask 2001}

Zask A, van Beurden E, Barnett L, Brooks LO, Dietrich UC. Active school playgrounds-myth or reality? Results of the "move it groove it" project. Preventive Medicine 2001;33(5):403-8.

\section{References to studies awaiting assessment}

\section{Castro 2001}

Castro CM, King AC, Brassington GS. Telephone versus mail interventions for maintenance of physical activity in older adults. Health Psychology 2001;20(6):438-44.

\section{Lowther 2002a}

Lowther M, Mutrie N, Scott EM. Promoting physical activity in a socially and economically deprived community: a 12 month randomized control trial of fitness assessment and exercise consultation. Journal of Sports Sciences 2002;20(7):577-88.

\section{Lowther 2002b}

Lowther M, Mutrie N, Scott EM. Promoting physical activity in a socially and economically deprived community: a 12 month randomized control trial of fitness assessment and exercise consultation. Journal of Sports Sciences 2002;20(7):577-88.

\section{Mutrie 2002}

Mutrie N, Carney C, Blamey A, Crawford F, Aitchison T, Whitelaw A. "Walk in to Work Out": a randomised controlled trial of a self help intervention to promote active commuting. Journal of Epidemiology \& Community Health 2002;56:407-12.

Nies 2003

Nies MA, Chruscial HL, Hepworth JT. An intervention to promote walking in sedentary women in the community. American Journal of Health Behavior 2003;27(5):524-35.

\section{Zakocs 2003}

Zakocs RC, Earp JA. Population-based randomized controlled trial of a stage-targeted physical activity intervention. Annals of Behavioral Medicine 2003;25(3):194-202.

\section{References to ongoing studies}

Coday 2002

Coday M, Klesges LM, Garrison RJ, Johnson KC, O’Toole M, Morris GS. Health Opportunities with Physical Exercise (HOPE): social contextual interventions to reduce sedentary behavior in urban settings. Health Education Research 2002;17(5):637-47.

\section{Grandes 2003}

Grandes G, Sánchez A, Torcal J, Ortega Sánchez-Pinilla R, Lizarraga $\mathrm{K}$, Serra J, et al.Protocol for the multi-centre evaluation of the Experimental Programme Promotion of Physical Activity (PEPAF) [Protocolo para la evaluacion multicentrica del Programa Experimental de Promocion de la Actividad Fisica (PEPAF)]. Atencion Primaria 2003; 32(8):475-80.

\section{King 2002}

King AC, Friedman R, Marcus B, Castro C, Forsyth L, Napolitano $\mathrm{M}$, Pinto B. Harnessing motivational forces in the promotion of physical activity: the Community Health Advice by Telephone (CHAT) project. Health Educucation Research 2002;17(5):627-36.

\section{Additional references}

\section{Ashworth 2005}

Ashworth NL, Chad KE, Harrison EL, Reeder BA, Marshall SC. Home versus center based physical activity programs in older adults. Cochrane Database of Systematic Reviews 2005, Issue 1.Art. No.: CD004017. DOI:10.1002/14651858.CD004017.pub2 .

\section{Bandura 1986}

Bandura A. Social foundations of thought and action. Englewood Cliffs, NJ: Prentice Hall, 1986.

\section{Dickersin 1995}

Dickersin K, Scherer, Lefebvre C. Identifying relevant studies from systematic reviews. In: ChalmersI, AltmanDG editor(s). Systematic Reviews. London: BMJ Publishing Group, 1995:64-74.

\section{DOH 2004}

Department of Health. At least five a week: evidence on the impact of physical activity and its relationship to health. A report from the Chief Medical Officer. London: Department of Health, 2004.

\section{DOH 2005a}

Department of Health. Health Survey for England 2004. London: The Stationary Office, 2005.

\section{DOH 2005b}

Department of Health. Choosing Activity: a physical activity action plan. London: Department of Health, 2005.

\section{FNB 2002}

Food, Nutrition Board (FNB). Institute of Medicine (IOM). Dietary Reference Intakes for Energy, Carbohydrate, Fiber, Fat, Fatty Acids, Cholesterol, Protein, and Amino Acids (Macronutrients). A Report of the Panel on Macronutrients, Subcommittees on Upper Reference Levels of Nutrients and Interpretation and Uses of Dietary Reference Intakes, and the Standing Committee on the Scientific Evaluation of Dietary Reference Intakes. Washington: National Academies Press, 2002:697-736.

\section{Folsom 1997}

Folsom AR, Arnett DK, Hutchinson RG, Liao F, Clegg LX, Cooper LS. Physical activity and incidence of coronary heart disease in middle-aged women and men. Medicine \& Science in Sports \& Exercise 1997;29:901-9.

\section{Higgins 2005}

Higgins JPT, Green S. Cochrane Handbook for Systematic Reviews of Interventions 4.2.5. John Wiley \& Sons, Ltd, 2005. 


\section{Hillsdon 1996}

Hillsdon M, Thorogood M. A systematic review of physical activty promotion strategies. British Journal of Sports Medicine 1996;30(2): 84-9.

\section{Hillsdon 1999}

Hillsdon M, Thorogood M, Foster C. A systematic review of physical activity promotion strategies. In: DMacAuley editor(s). Exercise Benefits and Risks. London: BMJ Press, 1999.

Hillsdon 2004

Hillsdon M, Foster C, Naidoo B, Crombie H. The effectiveness of public health interventions for increasing physical activity among adults: a review of reviews. London: Health Development Agency, 2004.

Hillsdon 2005

M Hillsdon, $\quad$ C $\quad$ Foster, $\quad M$ Thorogood. Interventions for promoting physical activity. Cochrane Database of Systematic Reviews 2005, Issue 1.Art. No.: CD003180. DOI:10.1002/14651858.CD003180.pub2.

HM Treasury 2002

HM Treasury. Public Service Agreements 2003 - 2006. London: HM Treasury, 2002.

\section{Jolliffe 2001}

Jolliffe JA, Rees K, Taylor RS, Thompson D, Oldridge N, Ebrahim S. Exercise-based rehabilitation for coronary heart disease. Cochrane Database of Systematic Reviews 2001, Issue 1.Art. No.: CD001800. DOI: $10.1002 / 14651858 . C D 001800$.

\section{Kahn 2002}

Kahn E B, Ramsey LT, Brownson RC, Health GW, Howze EH, Powell KE, et al.The effectiveness of interventions to increase physical activity: a systematic review. American Journal of Preventive Medicine 2002;22(4 Suppl):73-107.

Lefebvre 1996

Lefebvre C, McDonald S. Development of a sensitive search strategy for reports of randomised controlled trials in EMBASE. Paper presented at the Fourth International Cochrane Colloquium, 20 -24 Oct ; Adelaide, Australia. 1996.

Pate 1995

Pate RR, Pratt M, Blair SN, Haskell WL, Macera CA, Bouchard $\mathrm{C}$, et al.Physical activity and public health: a recommendation from the Centers for Disease Control and Prevention and the American College of Sports Medicine. JAMA 1995;273:402-7.

\section{Thomas 2006}

Thomas DE, Elliott EJ, Naughton GA. Exercise for type 2 diabetes mellitus. Cochrane Database of Systematic Reviews 2006, Issue 3.Art. No.: CD002968. DOI:10.1002/14651858.CD002968.pub2.

\section{US Dept. Health 1996}

US Department of Health and Human Services. Physical activity and health: a report of the surgeon general. Atlanta, GA: US Department of Health and Human Services, Centers for Disease Control and Prevention, National Center for Chronic Disease Prevention and Health Promotion, 1996.

\section{WHO 2002}

World Health Organisation. World Health Report 2002. Geneva: World Health Organisation, 2002.

\section{WHO 2004}

World Health Organisation. Global Strategy on diet, nutrition and physical activity. Geneva: World Health Organisation, 2004.

\section{Williams 2001}

Williams PT. Physical fitness and activity as separate heart disease risk factors: a meta-analysis. Medicine and Science in Sports and Exercise 2001;33(5):754-62.

\section{Zelen 1990}

Zelen, M. Randomized consent designs for clinical trials: an update. Statistics in Medicine 1990;9(6):645-6.

*Indicates the major publication for the study

T A B LE S

\section{Characteristics of included studies}

\begin{tabular}{ll} 
Study & Calfas $\mathbf{2 0 0 0}$ \\
\hline Methods & Randomised controlled trial \\
\hline Participants & University students \\
\hline Interventions & $\begin{array}{l}\text { Intervention group received a } 15 \text { week cognitive behavioural education course, } 15 \times 50 \text { minutes lectures } \\
\text { followed by } 15 \times 110 \text { minutes lab experience, led by peer health facilitators, plus homework including practice } \\
\text { of behavioural management strategies. Participants received } 2 \text { course credits and could attend supervised x2 } \\
\text { per week exercise sessions. All participants received } 15 \text { monthly follow up phone calls and monthly written } \\
\text { materials. }\end{array}$ \\
\hline Outcomes & + \\
\hline Self reported physical activity
\end{tabular}




\section{Characteristics of included studies (Continued)}

Participants volunteered to participate in a health course and attend a baseline assessment

Participants in both study arms had very high baseline levels of physical activity - mean $2+$ hours of vigorous

physical activity per week. Students also received academic credits for attending intervention sessions.

Allocation concealment $\mathrm{B}-$ Unclear

\begin{tabular}{ll} 
Study & Cunningham 1987 \\
\hline Methods & Randomised controlled trial \\
\hline Participants & Retirees from community centre \\
\hline Interventions & $\begin{array}{l}\text { Participants received 3 group exercise sessions per week and were encouraged to do one additional home } \\
\text { based session. }\end{array}$ \\
\hline Outcomes & + \\
& Self reported physical activity \\
& Cardio-respiratory fitness \\
\hline Notes & $\begin{array}{l}\text { Intervention group improved their fitness and vigorous physical activity levels versus control group. } \\
\text { All exercise sessions were conducted on an indoor or outdoor running track }\end{array}$ \\
\hline Allocation concealment & B - Unclear \\
\hline
\end{tabular}

\begin{tabular}{ll} 
Study & Dubbert $\mathbf{2 0 0 2}$ \\
\hline Methods & Randomised controlled trial \\
\hline Participants & Primary care patients \\
\hline Interventions & $\begin{array}{l}\text { All participants received a video, walking plan, weekly walking diary, (financial incentive for completing } \\
\text { diary), plus (1) } 20 \text { counselling, goal setting phone calls from nurse, or (2) 10 nurse calls and } 10 \text { automated } \\
\text { phone calls }\end{array}$ \\
\hline Outcomes & + \\
& $\begin{array}{l}\text { Self reported physical activity } \\
\text { Cardio-respiratory fitness }\end{array}$ \\
\hline Notes & No effect found for fitness changes but effect seen for dichotomous outcome \\
\hline Allocation concealment & B - Unclear \\
\hline
\end{tabular}

\begin{tabular}{ll} 
Study & Elley $\mathbf{2 0 0 3}$ \\
\hline Methods & Randomised controlled trial \\
\hline Participants & Primary care patients \\
\hline Interventions & Participants received motivation counselling from their general practitioner. This included discussion on \\
& increasing physical activity and goal setting. The participants received a green prescription card stating their \\
& recommended physical activity. After this meeting a local exercise specialist called all participants at least \\
& 3 times to encourage physical activity using motivational interviewing techniques. Written materials were \\
& also sent to participants every 3 months. These materials included information about local physical activity \\
& opportunities and motivational material. \\
\hline Outcomes & + \\
& Self reported physical activity \\
\hline Notes & B - Unclear \\
\hline Allocation concealment
\end{tabular}

Study

Goldstein 1999

Methods

Randomised controlled trial 


\begin{tabular}{|c|c|}
\hline \multicolumn{2}{|c|}{ Characteristics of included studies (Continued) } \\
\hline Participants & Primary care patients \\
\hline Interventions & $\begin{array}{l}\text { Participants received } 5 \text { minutes of stage of change matched counselling, plus a written prescription, materials } \\
\text { plus the chance of a follow up appointment. Participants also received } 5 \text { monthly mailed written materials. }\end{array}$ \\
\hline \multirow[t]{2}{*}{$\overline{\text { Outcomes }}$} & 0 \\
\hline & Self reported physical activity \\
\hline \multirow[t]{2}{*}{$\overline{\text { Notes }}$} & No difference in stage of change or in physical activity in elderly score \\
\hline & Active adults were excluded from the study \\
\hline Allocation concealment & B - Unclear \\
\hline
\end{tabular}

Study

\begin{tabular}{ll}
\hline Methods & Randomised controlled trial \\
\hline Participants & Health maintenance organisation members \\
\hline Interventions & $\begin{array}{l}\text { Participants received self help materials via mail, plus 3 x 20 minute phone calls per month for 3 months (up } \\
\text { to } 9 \text { calls). }\end{array}$ \\
\hline Outcomes & \begin{tabular}{l} 
Self reported physical activity \\
\hline Notes
\end{tabular} \\
\hline Allocation concealment & B - Unclear \\
\hline
\end{tabular}

\begin{tabular}{|c|c|}
\hline Study & Harland 1999 \\
\hline Methods & Randomised controlled trial \\
\hline Participants & Primary care patients \\
\hline Interventions & $\begin{array}{l}\text { All participants completed a baseline assessment of self reported physical activity, physical measures and cycle } \\
\text { ergometer fitness test. They received feedback of their results, brief advice about their present level of physical } \\
\text { activity and comparison to recommended levels, plus written health information, } 19 \text { leaflets about local } \\
\text { physical activity facilities and activities. In addition there were four intervention group, (i) one motivational } \\
\text { interview, (ii) one motivational interview plus vouchers for free use of local facilities, (iii) } 6 \text { motivational } \\
\text { interviews over } 12 \text { weeks and (iv) } 6 \text { motivational interviews over } 12 \text { weeks plus vouchers. }\end{array}$ \\
\hline Outcomes & $\begin{array}{l}0 \\
\text { Self reported physical activity }\end{array}$ \\
\hline$\overline{\text { Notes }}$ & $\begin{array}{l}\text { All intervention groups more active than control at } 12 \text { weeks, no differences at } 12 \text { months. } \\
\text { Two approaches to recruitment used opportunistic and all potential participants who attended the health } \\
\text { centre } \\
\text { Self reported vigorously active excluded from study } \\
\text { Moderate take up of motivational interviews amongst participants offered up to six - median } 3\end{array}$ \\
\hline Allocation concealment & B - Unclear \\
\hline
\end{tabular}

\section{Study}

Methods

Participants

Interventions

Outcomes

\section{Hillsdon 2002}

Randomised controlled trial

Primary care patients

Participants received brief negotiation plus follow up phone calls, or direct advice plus phone calls. 0

Self reported physical activity

Notes

Allocation concealment B - Unclear 


\section{Characteristics of included studies (Continued)}

Study

Methods

Participants

Interventions

\section{Inoue 2003}

Randomised controlled trial

Older Japanese women

Participants received feedback on their baseline assessments of exercise behaviour and fitness in 30 minute group lectures. Three exercise goals were recommended to participants. Participants were allowed to use the local research centre exercise facilities during the study. Participants received an 8-week intensive programme that provided each week one two hour session made up of one hour of group work and one hour of exercise practice. The group work included behavioural management skills based on stages of change. After 8 week all participants received newsletters every two months.

\begin{tabular}{ll}
\hline Outcomes & 0 \\
& Self reported physical activity \\
\hline Notes & \\
\hline Allocation concealment & B - Unclear \\
\hline
\end{tabular}

Study

Juneau 1987

Methods Randomised controlled trial

Participants Workplace employees

Interventions

Participants received a 30 minute consultation including watching a video, information on using a heart rate monitor and daily physical activity log. Participants were given a portable heart monitor, which warned the user if heart rate not in prescribed range. Participants were instructed to exercise at $65-77 \%$ peak baseline treadmill heart rate.

\begin{tabular}{ll}
\hline Outcomes & + \\
& Cardio-respiratory fitness
\end{tabular}

Increase in VO2 in intervention group improved over control group (approx 14\% in males, 10\% in female) Participants attended a screening session and a VO2 max test prior to randomisation

Allocation concealment $\mathrm{B}-$ Unclear

\begin{tabular}{ll} 
Study & King 1988a \\
\hline Methods & Randomised controlled trial \\
\hline Participants & Workplace employees \\
\hline Interventions & $\begin{array}{l}\text { Maintenance study participants received } 30 \text { minutes of baseline instruction (15 mins advice }+15 \text { mins video), } \\
\text { daily self monitoring of physical activity using exercise logs returned to staff every month. }\end{array}$ \\
\hline Outcomes & + \\
\hline Notes & Self reported physical activity \\
\hline Allocation concealment & B - Unclear \\
\hline
\end{tabular}

\begin{tabular}{ll} 
Study & King $\mathbf{1 9 8 8 b}$ \\
\hline Methods & Randomised controlled trial \\
\hline Participants & Workplace employees \\
\hline Interventions & $\begin{array}{l}\text { Adoption study participants received } 30 \text { minutes of baseline instruction (15 mins advice +15 mins video) } \\
\text { plus } 10 \text { staff initiated phone calls and self-monitoring materials including pulse monitor. }\end{array}$ \\
\hline Outcomes & Self reported physical activity \\
\hline Interventions for promoting physical activity (Review) \\
Copyright @ 2008 The Cochrane Collaboration. Published by John Wiley \& Sons, Ltd
\end{tabular}




\section{Characteristics of included studies (Continued)}

Notes

No significant difference in number of exercise sessions/month between groups but both groups increased physical activity over baseline.

Participants had previously taken part in an exercise RCT

Allocation concealment $\mathrm{B}-$ Unclear

\begin{tabular}{ll} 
Study & King $\mathbf{1 9 9 1}$ \\
\hline Methods & Randomised controlled trial \\
\hline Participants & Community older volunteers \\
\hline Interventions & $\begin{array}{l}\text { Participants received baseline physiological assessments and then were prescribed either home or group based } \\
\text { training at high or low intensity plus written information, physical activity logs and phone calls. }\end{array}$ \\
\hline Outcomes & + \\
& Cardio-respiratory fitness \\
\hline Notes & $\begin{array}{l}\text { Increase in VO2 max (approx 5\%) and treadmill duration (approx 14\%). Adherence greater in home based } \\
\text { arms } \\
\end{array}$ \\
$\begin{array}{l}\text { Participants agreed to attend an extensive medical and physical assessment if they wished to participate in } \\
\text { study }\end{array}$ \\
\hline Allocation concealment & B - Unclear \\
\hline
\end{tabular}

\begin{tabular}{ll} 
Study & Kriska $\mathbf{1 9 8 6}$ \\
\hline Methods & Randomised controlled trial \\
\hline Participants & Older women \\
\hline Interventions & $\begin{array}{l}\text { Participants received a baseline physical assessment, 8 week walking training programme with organised } \\
\text { walks, then choice of group or independent walking. Participants monitored their walking with monthly logs } \\
\text { and also were offered social meetings. Participants also received follow up phone calls, cards, and incentives } \\
\text { to maintain compliance. }\end{array}$ \\
\hline Outcomes & + Self reported physical activity \\
\hline Notes & $\begin{array}{l}\text { Significant different between intervention and control groups on walking blocks per day. } \\
\text { Frequency of follow up measures, meetings, mall walks and incentives not stated. }\end{array}$ \\
\hline Allocation concealment & B - Unclear \\
\hline
\end{tabular}

\begin{tabular}{ll} 
Study & Lamb $\mathbf{2 0 0 2}$ \\
\hline Methods & Randomised controlled trial \\
\hline Participants & Primary care patients \\
\hline Interventions & $\begin{array}{l}\text { Participants received a } 30 \text { minute group seminar, advice to exercise plus opportunity to attend health walks } \\
\text { programme and verbal and written information about groups. This group also received three phone calls to } \\
\text { encourage attendance and bring friends and family. }\end{array}$ \\
\hline Outcomes & $\begin{array}{l}\text { Self reported physical activity } \\
0 \\
\text { Cardio-respiratory fitness }\end{array}$ \\
\hline Notes & B - Unclear \\
\hline Allocation concealment &
\end{tabular}

\begin{tabular}{l} 
Study $\quad$ Lombard 1995 \\
\hline Methods Randomised controlled trial \\
\hline $\begin{array}{l}\text { Interventions for promoting physical activity (Review) } \\
\text { Copyright } \odot 2008 \text { The Cochrane Collaboration. Published by John Wiley \& Sons, Ltd }\end{array}$
\end{tabular}




\section{Characteristics of included studies (Continued)}

\begin{tabular}{ll} 
Participants & University staff \& students \\
\hline Interventions & $\begin{array}{l}\text { Participants were encouraged to walk in groups or with a friend and also received different frequencies and } \\
\text { intensities of follow up telephone calls plus written materials including walking maps }\end{array}$ \\
\hline Outcomes & + \\
& Self reported physical activity \\
\hline Notes & $\begin{array}{l}\text { Survival analysis showed that participants who received a high frequency of phone calls rather than a highly } \\
\text { structured call were more successful in sustaining walking over control and other groups. } \\
\end{array}$ \\
\hline Ollocation concealment 3 men in study $(2.2 \%)$ \\
\hline
\end{tabular}

\begin{tabular}{ll} 
Study & Marshall 2003a \\
\hline Methods & Randomised controlled trial \\
\hline Participants & Adult participants of an evaluation cohort \\
\hline Interventions & $\begin{array}{l}\text { Participants received one of } 4 \text { stages of change matched booklets, plus a motivational letter plus next stage } \\
\text { of change booklet. }\end{array}$ \\
\hline Outcomes & \begin{tabular}{l} 
Self reported physical activity \\
\hline Notes
\end{tabular} \\
\hline Allocation concealment & B - Unclear \\
\hline
\end{tabular}

\begin{tabular}{ll} 
Study & Marshall 2004 \\
\hline Methods & Randomised controlled trial \\
\hline Participants & Community living adults \\
\hline Interventions & $\begin{array}{l}\text { Participants received a booklet that matched their stage of change plus the booklet for the following stage } \\
(\text { same materials as Marshall et al 2003). Participants also received a motivational letter. }\end{array}$ \\
\hline Outcomes & \begin{tabular}{l} 
Self reported physical activity \\
\hline Notes
\end{tabular} \\
\hline Allocation concealment & B - Unclear \\
\hline
\end{tabular}

\begin{tabular}{ll} 
Study & Norris $\mathbf{2 0 0 0}$ \\
\hline Methods & Randomised controlled trial \\
\hline Participants & Health maintenance organisation members \\
\hline Interventions & $\begin{array}{l}\text { Stage matched strategies and written materials given to patient prior to counselling with physician. Physician } \\
\text { delivered behavioural counselling appropriate to stages of change model, with goal setting, identifying barriers, } \\
\text { problem solving and contracting techniques, plus a written prescription for exercise. Patients also received } \\
\text { single follow up phone call. }\end{array}$ \\
\hline Outcomes & $\begin{array}{l}\text { Self reported physical activity } \\
\text { Notes }\end{array}$ \\
\hline No significant differences between groups at 6 months \\
Allocation concealment & B - Unclear \\
\hline
\end{tabular}

\section{Study}

\section{Petrella 2003}

Methods

Randomised controlled trial 


\section{Characteristics of included studies (Continued)}

Participants

Interventions
Primary health care patients

Participants received a fitness assessment using a step test and counselling from physician. Each participant was given examples of exercise and the ACSM prescription of physical activity using heart rate reserve (HRR). Participants were asked to record their weekly exercise in a diary which was collected at 3, 6 and 12 months. Participants also received information about local exercise facilities and activities.

\begin{tabular}{ll}
\hline Outcomes & + \\
& Cardio-respiratory fitness \\
\hline Notes & \\
\hline Allocation concealment & D - Not used \\
\hline
\end{tabular}

\begin{tabular}{ll} 
Study & Pinto $\mathbf{2 0 0 2}$ \\
\hline Methods & Randomised controlled trial \\
\hline Participants & Health maintenance organisation members \\
\hline Interventions & $\begin{array}{l}\text { Participants received computer-based telephone calls and wore a pedometer. Participants were asked to call } \\
\text { every week for three months and at least twice a month for the next three months. The calls assessed present } \\
\text { levels of moderate intensity physical activity, daily pedometer scores, motivation and provided stage matched } \\
\text { advice. Monthly written reports were generated from calls and sent to participants. }\end{array}$ \\
\hline Outcomes & \begin{tabular}{l} 
Self reported physical activity \\
\hline Notes
\end{tabular} \\
\hline Allocation concealment & B - Unclear \\
\hline
\end{tabular}

\section{Study}

Methods

Participants

Interventions

\section{Reid 1979}

Randomised controlled trial

Male fire fighters

Pre randomisation fitness assessment, feedback by physician of fitness results compared population levels, prescription for exercise appropriate for age. Group one received additional one hour of health education, film, written \& verbal advice. Group two received self-monitoring materials and a weekly record, which were returned to research staff bi-weekly. All participants reported monthly on exercise programme.

\begin{tabular}{ll}
\hline Outcomes & 0 \\
& Compliance index score \\
\hline Notes & Short term significant improvement in compliance index (VO2+exercise freq.) not maintained at 6 months. \\
& Participants agreed to attended a screening session prior to randomisation \\
& Active fire fighters were excluded from study \\
\hline Allocation concealment & B - Unclear \\
\hline
\end{tabular}

\section{Study}

\section{Resnick 2002a}

Methods Randomised controlled trial

Participants Adults from retirement community

Interventions

Participants received the WALC intervention. All participants were invited to join a walking group (meeting 6 times a week) or walk on their own 3 times a week. Pain was assessed by nurse once a week for four weeks then once a month for 5 months. Participants received written materials and these were used in a short review with their nurse. Participants received a calendar to remind them about walking goals and record walking frequency.

\begin{tabular}{ll}
\hline Outcomes & 0 \\
& Self reported physical activity
\end{tabular}

Interventions for promoting physical activity (Review)

Copyright @ 2008 The Cochrane Collaboration. Published by John Wiley \& Sons, Ltd 


\section{Characteristics of included studies (Continued)}

Notes

Allocation concealment $\mathrm{B}-$ Unclear

\begin{tabular}{|c|c|}
\hline Study & SSCT 2000 \\
\hline Methods & Randomised controlled trial \\
\hline Participants & Older Japanese adults \\
\hline Interventions & $\begin{array}{l}\text { Participants were encouraged to attend at least } 2 \text { from } 3 \text { 2-hour exercise classes per week, held at a local } \\
\text { community centre. The class contained endurance and resistance training. }\end{array}$ \\
\hline Outcomes & $\begin{array}{l}+ \\
\text { Self reported physical activity } \\
(\text { Fujita 2003) } \\
+ \\
\text { Cardio-respiratory fitness } \\
\text { (Tsuji 2000) }\end{array}$ \\
\hline \multicolumn{2}{|l|}{ Notes } \\
\hline Allocation concealment & B - Unclear \\
\hline
\end{tabular}

Study Simons-Morton 2001a

\begin{tabular}{ll}
\hline Methods & Randomised controlled trial \\
\hline Participants & Primary care patients \\
\hline Interventions
\end{tabular}

Interventions Participants were randomised to one of three groups, advice, assistance or counselling. The assistance group received the same advice as the advice for a physician but the health educator conducted a 30-40 minute counselling session, including a videotape and action planning. Participants then received follow up phone calls, interactive mail, an electronic step counter, and monthly monitoring cards, which were returned to the health educator. Follow up mail was returned plus incentive to all participants. The counselling group received all of components of the advice and assistance group with in addition telephone-counselling calls. Weekly behavioural classes were also offered to this group.

\begin{tabular}{ll}
\hline Outcomes & 0 \\
& Self reported physical activity \\
& 0 \\
& Cardio-respiratory fitness \\
\hline Notes & No differences in physical activity. No differences for either fitness or physical activity in any male group. \\
& Participants undertook three sessions of pre-screening before randomisation. \\
\hline Allocation concealment & B - Unclear \\
\hline
\end{tabular}

\begin{tabular}{ll} 
Study & Simons-Morton $\mathbf{2 0 0 1 b}$ \\
\hline Methods & Randomised controlled trial \\
\hline Participants & Primary care patients \\
\hline Interventions & Participants were randomised to one of three groups, advice, assistance or counselling. The assistance group
\end{tabular}
received the same advice as the advice for a physician but the health educator conducted a 30-40 minute counselling session, including a videotape and action planning. Participants then received follow up phone calls, interactive mail, an electronic step counter, and monthly monitoring cards, which were returned to the health educator. Follow up mail was returned plus incentive to all participants. The counselling group received all of components of the advice and assistance group with in addition telephone-counselling calls. Weekly behavioural classes were also offered to this group.

\begin{tabular}{ll}
\hline Outcomes & Self reported physical activity \\
Cardio-respiratory fitness
\end{tabular}

Interventions for promoting physical activity (Review)

Copyright $(2008$ The Cochrane Collaboration. Published by John Wiley \& Sons, Ltd 


\section{Characteristics of included studies (Continued)}

Notes

Women's VO2 increased in assistance group and counselling group compared to the advice group. No differences in physical activity.

Participants undertook three sessions of pre-screening before randomisation.

Allocation concealment $\mathrm{B}$ - Unclear

Study

Smith 2000

Methods Randomised controlled trial

Participants Primary care patients

Interventions $\quad$ Participants received GP advice, or GP advice plus stage matched booklets via post

Outcomes 0

Self reported physical activity

Notes Short-term (6-10 weeks) increase in physical activity for advice plus booklet group versus controls only for participants inactive at baseline .

Potential participants with poor English were excluded. Active subjects included in study but final results adjusted for baseline physical activity status

Allocation concealment $\mathrm{D}-$ Not used

\begin{tabular}{ll} 
Study & Stevens $\mathbf{1 9 9 8}$ \\
\hline Methods & Randomised controlled trial \\
\hline Participants & Primary care patients \\
\hline Interventions & $\begin{array}{l}\text { Participants were invited by their GP to attend a consultation with an exercise development officer. At } \\
\text { this meeting they discussed their present physical activity and were encouraged to increase on their current } \\
\text { physical activity choices rather than start anything new. A follow up appointment was made ten weeks later. }\end{array}$ \\
\hline Outcomes & + \\
& Self reported physical activity \\
\hline Notes & $\begin{array}{l}\text { Significant increase in occasions of exercise in past 4 weeks in intervention v control groups } \\
\text { Active participants at baseline were not randomised }\end{array}$ \\
& MH \& MT were study authors \\
\hline Allocation concealment & B - Unclear
\end{tabular}

\begin{tabular}{ll} 
Study & Stewart $\mathbf{2 0 0 1}$ \\
\hline Methods & Randomised controlled trial \\
\hline Participants & Community dwelling older adults \\
\hline Interventions & $\begin{array}{l}\text { SCT based face to face counseling, behavioural, cognitive techniques to use local exercise opportunities } \\
\text { or develop own programs. Participants also attended informational meetings, individual planning sessions, } \\
\text { monthly group workshops, received physical activity diaries, telephone calls, newsletters, and functional } \\
\text { fitness assessments. Participants were strongly encouraged to attend first two of ten workshops where a } \\
\text { walking clinic was offered. }\end{array}$ \\
\hline Outcomes & + \\
& Self reported physical activity \\
\hline Notes & $\begin{array}{l}\text { Greater increase in moderate physical activity in intervention group versus control at } 12 \text { months } \\
\text { High baseline levels of physical activity - 1052 kcals/week moderate LTPA, 1935 kcals/week for all physical } \\
\text { activities }\end{array}$ \\
\hline Allocation concealment & B - Unclear \\
\hline Interventions for promoting physical activity (Review) \\
Copyright @ 2008 The Cochrane Collaboration. Published by John Wiley \& Sons, Ltd
\end{tabular}




\section{Characteristics of excluded studies}

\begin{tabular}{|c|c|}
\hline Study & Reason for exclusion \\
\hline Andersen 1999 & Study aim irrelevant \\
\hline Andersen 2002 & Study aim irrelevant \\
\hline Aoun 2002 & Study aim irrelevant \\
\hline Asikainen 2002 & Review paper \\
\hline Asikainen 2003 & Study aim irrelevant \\
\hline Atienza 2001 & Review paper \\
\hline Atlantis 2004 & Study aim irrelevant \\
\hline Ballantyne 1978 & Study aim irrelevant \\
\hline Baranowski 1990 & Less than 6 months follow up \\
\hline Baranowski 2003 & Study aim irrelevant \\
\hline Barnett 2003 & Study aim irrelevant \\
\hline Bauman 2001 & Study aim irrelevant \\
\hline Bell 2001 & Study aim irrelevant \\
\hline Blair 1986 & Non-randomised study \\
\hline Blumenthal 2000 & Study aim irrelevant \\
\hline Bonet 2003 & Study aim irrelevant \\
\hline Brownson 2004 & Non-randomised study \\
\hline Buijis 2003 & Study aim irrelevant \\
\hline Bull 1998 & Loss to follow up > 20\% \\
\hline Burke 2003 & Study aim irrelevant \\
\hline Calfas 2002 & Study aim irrelevant \\
\hline Campbell 1985 & Non-randomised study \\
\hline Cardinal 1996 & Less than 6 months follow up \\
\hline Carels 2004 & Study aim irrelevant \\
\hline Castro 2002 & Review paper \\
\hline Chang 2003 & Non-randomised study \\
\hline Clark 2003 & Non-randomised study \\
\hline Coleman 1999 & No appropriate control group \\
\hline Collins 2004 & Study aim irrelevant \\
\hline Conn 2002 & Study aim irrelevant \\
\hline Conn 2003 & Less than 6 months follow up \\
\hline Dallow 2003 & No appropriate control group \\
\hline De Jong 2004 & Study aim irrelevant \\
\hline Donnelly 2000 & Study aim irrelevant \\
\hline DuVall 2004 & Less than 6 months follow up \\
\hline Dunn 1997 & No appropriate control group \\
\hline Dunn 1998 & No appropriate control group \\
\hline$\overline{\text { Eakin } 2000}$ & Review paper \\
\hline
\end{tabular}




\begin{tabular}{|c|c|}
\hline Eaton 1998 & Review paper \\
\hline Ebrahim 1997 & Study aim irrelevant \\
\hline Ebrahim 1998 & Review paper \\
\hline Elberson 2001 & Study aim irrelevant \\
\hline Elliot 2004 & Study aim irrelevant \\
\hline Emmons 1999 & Multiple risk factor intervention \\
\hline Eriksen 2002 & Study aim irrelevant \\
\hline Fahrenwald 2002 & Study aim irrelevant \\
\hline Fiatarone 1994 & Study aim irrelevant \\
\hline Focht 2004 & Study aim irrelevant \\
\hline Fody-Urias 2001 & Study aim irrelevant \\
\hline Fritz 2001 & Study aim irrelevant \\
\hline Froehlich-Grobe 2004 & Study aim irrelevant \\
\hline Furukawa 2003 & Study aim irrelevant \\
\hline Godin 1987 & Less than 6 months follow up \\
\hline Goldwater 1985 & Less than 6 months follow up \\
\hline Gossard 1986 & Less than 6 months follow up \\
\hline Graham-Clarke 1994 & Multiple risk factor intervention \\
\hline Granner 2001 & Study aim irrelevant \\
\hline Halbert 1999 & Study aim irrelevant \\
\hline Halbert 2000 & Insufficient data, author uncontactable \\
\hline Halbert 2001 & Study aim irrelevant \\
\hline Hamdorf 1999 & Loss to follow up $>20 \%$ \\
\hline Hamdorf 2002 & Study aim irrelevant \\
\hline Harrell 1996 & No appropriate control group \\
\hline Heinonen 1999 & Study aim irrelevant \\
\hline Hellenius 1995 & Study aim irrelevant \\
\hline Hellenius 1997 & Study aim irrelevant \\
\hline Hirvensalo 2003 & Study aim irrelevant \\
\hline Hopman-Rock 2002 & Study aim irrelevant \\
\hline Huang 2002 & Study aim irrelevant \\
\hline Humpel 2004 & Less than 6 months follow up \\
\hline Jakicic 1995 & No appropriate control group \\
\hline Jakicic 1999 & No appropriate control group \\
\hline Jette 1996 & Less than 6 months follow up \\
\hline Jobe 2001 & Study aim irrelevant \\
\hline Kaukiainen 2002 & Study aim irrelevant \\
\hline Keele-Smith 2003 & Less than 6 months follow up \\
\hline Kelley 2004 & Study aim irrelevant \\
\hline Kennedy 2003 & Study aim irrelevant \\
\hline Kerr 2000 & No appropriate control group \\
\hline
\end{tabular}




\begin{tabular}{|c|c|}
\hline Kim 2004 & Study aim irrelevant \\
\hline King 1984 & Less than 6 months follow up \\
\hline King 1995 & Study aim irrelevant \\
\hline King 1997 & Study aim irrelevant \\
\hline King 2000 & Study aim irrelevant \\
\hline \multicolumn{2}{|l|}{ King 2001} \\
\hline Kinion 1993 & Study aim irrelevant \\
\hline Kirk 2001 & Study aim irrelevant \\
\hline Kirk 2004 & Study aim irrelevant \\
\hline Kirk-Gardner 2003 & Study aim irrelevant \\
\hline Koffman 2001 & Non-randomised study \\
\hline Kohno 2002 & Non-randomised study \\
\hline Kontulainen 2004 & Study aim irrelevant \\
\hline Kukkonen-H 1998 & Study aim irrelevant \\
\hline Lansdown 2002 & Less than 6 months follow up \\
\hline Lawlor 2001 & Review paper \\
\hline Leon 1996 & Study aim irrelevant \\
\hline Lewis $1993 \mathrm{a}$ & Under 16 s included \\
\hline Lewis $1993 \mathrm{~b}$ & Less than 6 months follow up \\
\hline Li 2001 & Study aim irrelevant \\
\hline Lindstrom 2003 & Study aim irrelevant \\
\hline Little 2004 & Less than 6 months follow up \\
\hline Lord 1995 & Non-randomised study \\
\hline Lupton 2002 & Study aim irrelevant \\
\hline MacKeen 1985 & Loss to follow up $>20 \%$ \\
\hline Manson 1999 & Study aim irrelevant \\
\hline Marcus 1992 & Non-randomised study \\
\hline Marcus 1993 & Less than 6 months follow up \\
\hline Marcus 1995 & Study aim irrelevant \\
\hline Marcus 1998a & Less than 6 months follow up \\
\hline Marcus 1998b & Loss to follow up $>20 \%$ \\
\hline Marshall 2003b & Less than 6 months follow up \\
\hline Martin 2004 & Study aim irrelevant \\
\hline Mattila 2003 & Study aim irrelevant \\
\hline McAuley 1994 & Less than 6 months follow up \\
\hline McMahon 2002 & Study aim irrelevant \\
\hline McMurdo 1992 & Study aim irrelevant \\
\hline McMurdo 1995 & Study aim irrelevant \\
\hline Messier 2000 & Study aim irrelevant \\
\hline Miller 2002 & Loss to follow up $>20 \%$ \\
\hline Mills 1996 & Study aim irrelevant \\
\hline
\end{tabular}




\begin{tabular}{|c|c|}
\hline Milne 2002 & Less than 6 months follow up \\
\hline Mulder 1981 & Study aim irrelevant \\
\hline Munsch 2003 & Study aim irrelevant \\
\hline Napolitano 2003 & Less than 6 months follow up \\
\hline Naylor 1999 & Non-randomised study \\
\hline Newman 2002 & Review paper \\
\hline Nisbeth 2000 & Study aim irrelevant \\
\hline Noland 1989 & Less than 6 months follow up \\
\hline Nurminen 2002 & Study aim irrelevant \\
\hline Oexmann 2001 & Study aim irrelevant \\
\hline Oida 2003 & Study aim irrelevant \\
\hline Oman 2000 & Study aim irrelevant \\
\hline Ortega-Sanchez 2004 & Under 16 s included \\
\hline Ostwald 1989 & Study aim irrelevant \\
\hline Parks 1997 & Non-randomised study \\
\hline Partonen 1998 & Study aim irrelevant \\
\hline Paschal 2004 & Study aim irrelevant \\
\hline Pereira 1998 & Study aim irrelevant \\
\hline Peterson 1999 & Less than 6 months follow up \\
\hline Peterson 2002 & Study aim irrelevant \\
\hline Petrella 2000 & Study aim irrelevant \\
\hline Petrella 2001 & Study aim irrelevant \\
\hline Pfeiffer 2001 & Less than 6 months follow up \\
\hline Philips 2004 & Study aim irrelevant \\
\hline Pinto 2001 & Study aim irrelevant \\
\hline Plotnikoff 2001 & Study aim irrelevant \\
\hline Pohjonen 2001 & Non-randomised study \\
\hline Poole 2001 & Study aim irrelevant \\
\hline Poston 2001 & Loss to follow up $>20 \%$ \\
\hline Proper 2003a & Study aim irrelevant \\
\hline Proper 2003b & Review paper \\
\hline Purath 2004 & Less than 6 months follow up \\
\hline Reijneveld 2003 & Study aim irrelevant \\
\hline Renger 2002 & Non-randomised study \\
\hline Resnick 2002b & Study aim irrelevant \\
\hline Reynolds 2001 & Review paper \\
\hline Robison 1992 & Under 16 s included \\
\hline Ruby 1993 & Less than 6 months follow up \\
\hline Samaras 1997 & Subjects with chronic disease \\
\hline Schoenfelder 2000 & Study aim irrelevant \\
\hline Schuler 2002 & Study aim irrelevant \\
\hline
\end{tabular}




\section{Characteristics of excluded studies (Continued)}

\begin{tabular}{|c|c|}
\hline 2002 & Study aim irrelevant \\
\hline Sevick 2000 & No appropriate control group \\
\hline Simmons 2003 & Study aim irrelevant \\
\hline Sims 2004 & Study aim irrelevant \\
\hline Singh 1997 & Study aim irrelevant \\
\hline Singh $1997 \mathrm{a}$ & Less than 6 months follow up \\
\hline Smith 2003 & Non-randomised study \\
\hline Smolander 2000 & No appropriate control group \\
\hline Sorensen 1999 & Study aim irrelevant \\
\hline Steptoe 1999 & Multiple risk factor intervention \\
\hline Steptoe 2000 & Study aim irrelevant \\
\hline Steptoe 2001 & Study aim irrelevant \\
\hline Stevens 1999 & Non-randomised study \\
\hline Stevens 2003 & Non-randomised study \\
\hline Stiggelbout 2004 & Less than 6 months follow up \\
\hline Swinburn 2003 & Review paper \\
\hline Taylor 1998 & Loss to follow up $>20 \%$ \\
\hline Twisk 2004 & Study aim irrelevant \\
\hline Veverka 2003 & Study aim irrelevant \\
\hline Votruba 1968 & Review paper \\
\hline Vuori 1994 & Less than 6 months follow up \\
\hline Wankel 1985 & Less than 6 months follow up \\
\hline Weinehall 2001 & Study aim irrelevant \\
\hline Wen 2002 & Non-randomised study \\
\hline Wilbur 2001 & Study aim irrelevant \\
\hline Wood 1983 & Study aim irrelevant \\
\hline Woods 2002 & Study aim irrelevant \\
\hline Yalden 2001 & Study aim irrelevant \\
\hline Yanek 2001 & Study aim irrelevant \\
\hline Young 1999 & Study aim irrelevant \\
\hline Zask 2001 & Study aim irrelevant \\
\hline van der Bij 2002 & Review paper \\
\hline
\end{tabular}


A D D I T I O N A L TAB LES

\section{Table 01. Search Strategy for EMBASE}

Dates 2000 to 2004

1. (((health-education) or (health-education-research)) or ((patient-education) or (patient-education-and-counseling)) or ((healthpromotion) or (health-promotion-international)) or (primary-health-care) or ((workplace) or (workplace-)) or (promot $\left.{ }^{*}\right)$ or $\left(\left(\right.\right.$ promot $\left.^{*}\right)$ or $\left(\left(\right.\right.$ educat $\left.^{*}\right)$ or $\left(\left(\right.\right.$ program $\left.{ }^{*}\right)$ and $((($ exertion) or (fitness) or (fitness-) or ((fitness) or (fitness-)) or (exercise) or ((exercise) or (sport) or $\left(\right.$ walk $\left.\left.\left.^{*}\right)\right)\right)$

2.((research) or (((((random-controlled) or (random-sample) or (randomisation) or (randomised) or (randomised-controlled) or (randomization) or (randomization-) or (randomizd) or (randomize) or (randomized) or (randomized-block) or (randomizedcontrolled) or (randomized-controlled-trial) or (randomized-control)) or ((double-blind) or (double-blind-procedure)) or ((singleblind) or (single-blind-procedure $))$ ) and (ec=human $))$ or (clinical) or $\left(\right.$ clin* $\left.^{*}\right)$ or $\left(\right.$ trial $\left.^{*}\right)$ or $\left(\left(\left(\right.\right.\right.$ clin* $^{*}$ near trial*) in ti) and (ec=human $\left.)\right)$ or

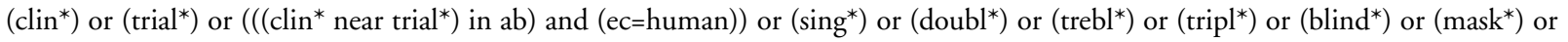
$\left(\left(\left(\right.\right.\right.$ sing* $^{*}$ or doubl* or trebl* or tripl*) near (blind* or mask*) $\left.{ }^{*}\right)$ and (ec=human $\left.)\right)$ or ((placebos) or (placebo-controlled)) or ((placebo* in ti) and (ec=human) $)$ or ((placebo* in ab) and (ec=human)) or ((random* in ti) and (ec=human) $)$ or ((random in ab) and (ec=human)) or (research)) ec=human)

3.(((studies) or (prospective-study) or (follow-up) or (comparative) or (evaluation)) and (ec=human))

\section{Table 02. Search Strategy for CINAHL}

Dates 2000 to 2004

1.exact $\{$ controlled\}

2.exact $\{$ randomized $\}$

3.exact $\{$ random-assignment

4.exact $\{$ double-blind

5.exact $\{$ single-blind $\}$

$6 . \# 1$ or $\# 2$ or \#3 or \#4 or \#5

7.exact $\{$ animal $\}$

8.exact \{human\}

9.\#6 not \#7

10.exact $\{$ clinical $\}$

11. (clin* near trial $\left.{ }^{*}\right)$ in ti

12. $\left(\right.$ clin* near trial*) $^{*}$ in $\mathrm{ab}$

13. (singl* or doubl* or trebl* or tripl*) near (blind* or mask ${ }^{*}$ )

14. (\#13 in ti) or (\#13 in ab)

15.placebos

16. placebo* in ti

17. placebo* $^{*}$ in ab

18.random* in ti

19. random* in ab

20.exact $\{$ research-methodology\}

$21 . \# 10$ or $\# 11$ or $\# 12$ or \#13 or \#14 or \#15 or \#16 or \#17

22.\#18 or \#19 or \#20

23.\#21 or \#22

24.animal

25.human

26.\#23 not \#24

Interventions for promoting physical activity (Review)

Copyright (c) 2008 The Cochrane Collaboration. Published by John Wiley \& Sons, Ltd 
Table 02. Search Strategy for CINAHL (Continued)

\section{Dates 2000 to 2004}

27.\#26 or \#9 or \#8 or \#25

28.exact \{comparative\}

29.study

$30 . \# 28$ and \#29

31.exact $\{$ evaluation\}

32.studies

33.\#31 and \#32

34.exact \{follow-up\}

35.exact $\{$ propsective

$36 . \# 35$ and $\# 32$

37.control* or prosepctiv* or volunteer*

38.(\#37 in ti) or (\#37 in ab)

39 . \#38 or \#36 or \#33 or \#30

$40 . \# 39$ not \#24

$41 . \# 39$ or \#27 or \#9

42.explode "exertion/"/ all subheadings

43. "physical fitness"

44.explode "physical education and training"/ all subheadings

45.explode "sports"/ all subheadings

46.explode "dancing"/ all subheadings

47.explode "exercise therapy"/ all subheadings

48. (physical\$ adj5 (fit $\$$ or train $\$$ or activ\$ or endur $\$$ )).tw.

49. (exercis\$ adj5 (train\$ or physical\$ or activ\$)).tw.

50.sport\$.tw.

51.walk\$.tw.

52.bicycle $\$ . t w$

53. (exercise $\$$ adj aerobic $\$$ ).tw.

54.(("lifestyle" or life-style) adj5 activ\$).tw.

55.(("lifestyle" or life-style) adj5 physical\$).tw.

$56 . \# 42$ or \#43 or \#44 or \#45 or \#46 or \#47 or \#48 or \#49 or (exercise\$) or (aerobic\$) or ("lifestyle") or (activ\$) or ("lifestyle") or (lifestyle) or (physical\$)

57.health education

58.patient education

59.primary prevention

60.health promotion

61.behaviour therapy

62.cognitive therapy

63.primary health care

64.workplace

65.promot\$.tw.

66.educat\$.tw.

67.program $\$$.tw.

$68 . \# 57$ or \#58 or \#59 or \#60 or \#61 or \#62 or \#63 or \#64 or \#65 or \#66 or \#67

69.\#68 and \#56

$70 . \# 69$ and \#41 


\section{Table 03. Search Startegy for PsycLIT}

Dates 2000 to 2004

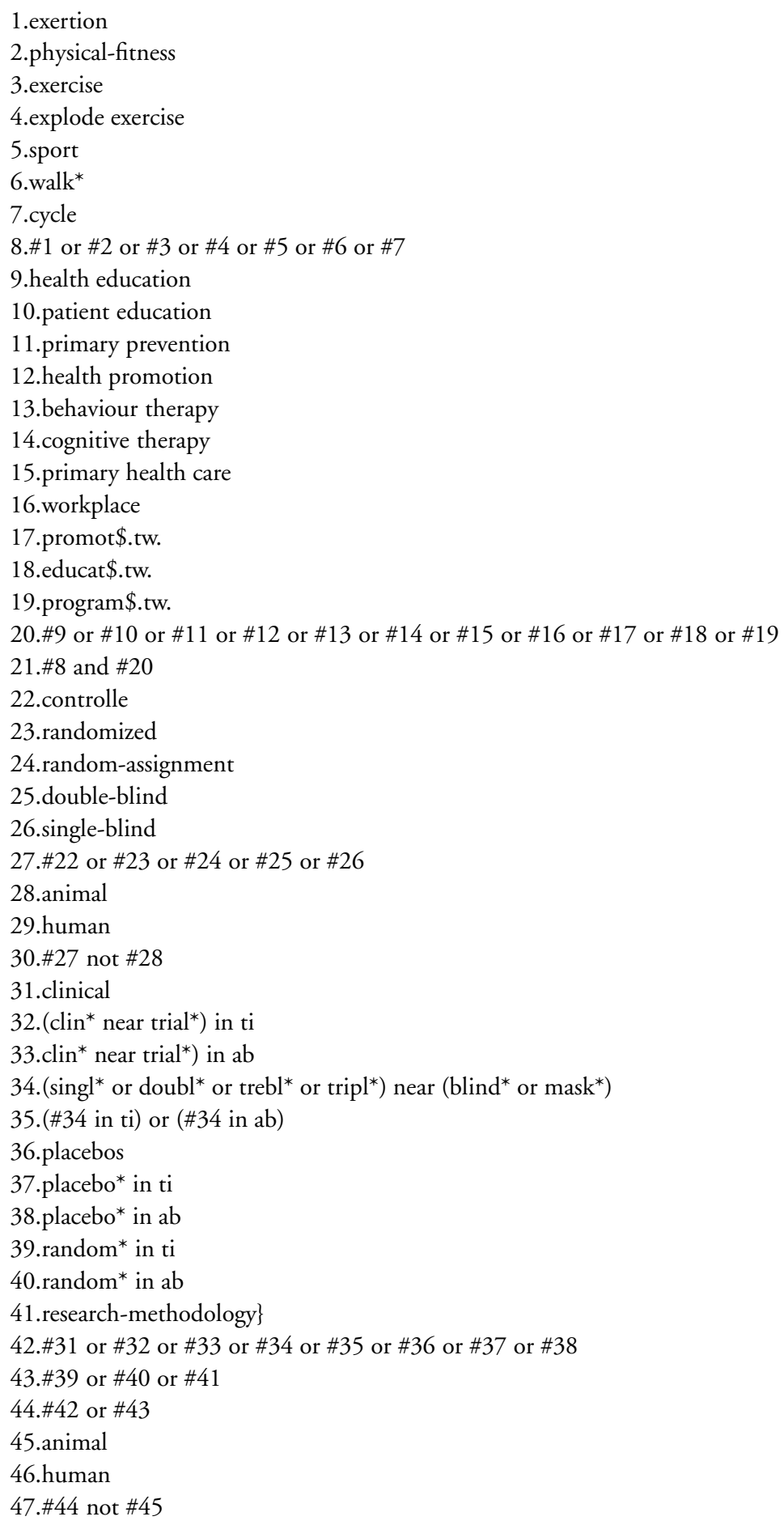

Interventions for promoting physical activity (Review) 
Table 03. Search Startegy for PsycLIT (Continued)

\section{Dates 2000 to 2004}

$48 . \# 47$ or \#30 or \#29 or \#46

49.comparative

50.study

51.\#49 and \#50

52.evaluation

53.studies

54.\#52 and \#53

55.follow-up

56.propsective

57.\#56 and \#53

58.control* or prosepctiv* or volunteer*

59. (\#58 in ti) or (\#58 in ab)

$60 . \# 59$ or $\# 57$ or $\# 54$ or \#51

61.\#60 not \#45

$62 . \# 60$ or \#48 or \#30

63.\#62 and \#21

\section{Table 04. Search Startegy SPORTSDISCUS}

\section{Dates 2000 to 2004}

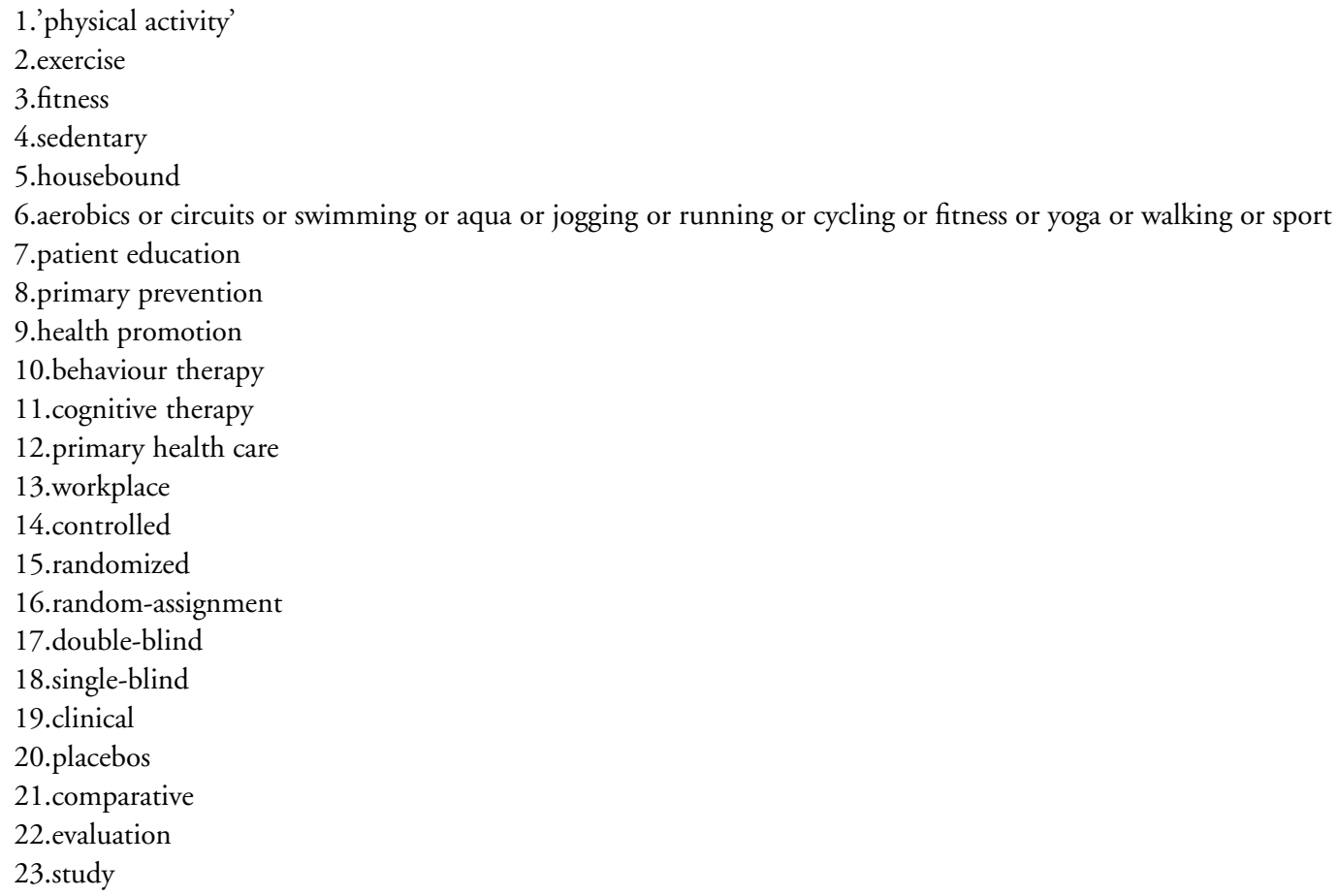


Table 05. Search Strategy SIGLE

Dates 2000 to 2004

1.explode "Exertion/"/ all subheadings

2."Physical fitness"

3.explode "Physical education and training"/ all subheadings

4.explode "Sports"/ all subheadings

5.explode "Dancing"/ all subheadings

6.explode "Exercise therapy"/ all subheadings

7.(physical\$ adj5 (fit $\$$ or train $\$$ or activ $\$$ or endur\$)).tw.

8. (exercis\$ adj5 (train $\$$ or physical\$ or activ\$)).tw.

9.sport\$.tw.

10.walk\$.tw.

11.bicycle\$.tw

12. (exercise $\$$ adj aerobic $\$$ ).tw.

13.(("lifestyle" or life-style) adj5 activ\$).tw.

14.(" "lifestyle" or life-style) adj5 physical\$).tw.

$15 . \# 1$ or $\# 2$ or $\# 3$ or $\# 4$ or \#5 or \#6 or \#7 or \#8 or (exercise\$) or (aerobic\$) or ("lifestyle") or (activ\$) or ("lifestyle") or (life-style) or (physical\$)

16.Health Education

17.Patient education

18.Primary prevention

19. Health promotion

20.Behaviour therapy

21. Cognitive therapy

22.Primary health care

23. Workplace

24.promot\$.tw.

25.educat\$.tw.

26.program\$.tw.

$27 . \# 16$ or \#17 or \#18 or \#19 or \#20 or \#21 or \#22 or \#23 or \#24 or \#25 or \#26

28.\#15 and \#27

\section{Table 06. Search Strategy SCISEARCH}

\section{Dates 2000 to 2004}

1.((promot $\$$ or uptake or encourag $\$$ or increas $\$$ or start) near (physical adj activity))

2.(promot $\$$ or uptake or encourag $\$$ or increas $\$$ or start) near exercise

3. (promot $\$$ or uptake or encourag $\$$ or increas $\$$ or start) near (aerobics or circuits or swimming or aqua $\$$ )

4.(promot $\$$ or uptake or encourag $\$$ or increas $\$$ or start) near (jogging or running or cycling)

5.(promot $\$$ or uptake or encourag $\$$ or increas $\$$ or start) near ( (keep adj fit) or (fitness adj class $\$$ ) or yoga)

6.(promot $\$$ or uptake or encourag $\$$ or increas $\$$ or start) near walking

7.(promot $\$$ or uptake or encourag $\$$ or increas $\$$ or start) near sport $\$$ 
Table 07. Descriptive data for review studies

\begin{tabular}{|c|c|c|c|c|c|c|}
\hline Author & Publication year & Setting & No. randomised & $\%$ Male & Age range & $\begin{array}{l}\text { Authors' } \\
\text { description }\end{array}$ \\
\hline Reid 1979 & 1979 & Workplace & 124 & 100 & 24 to 56 & $\begin{array}{l}\text { Endurance } \\
\text { activities }\end{array}$ \\
\hline Kriska 1986 & 1986 & Community & 229 & 0 & 50 to 65 & Walking \\
\hline Cunningham 1987 & 1987 & $\begin{array}{l}\text { Workplace / } \\
\text { community }\end{array}$ & 224 & 100 & 54 to 68 & $\begin{array}{l}\text { Walking, jogging or } \\
\text { running }\end{array}$ \\
\hline Juneau 1987 & 1987 & Workplace & 120 & 50 & 40 to 60 & $\begin{array}{l}\text { Walking or slow } \\
\text { jogging }\end{array}$ \\
\hline King 1988a & 1988 & Workplace & 52 & 50 & 40 to 60 & $\begin{array}{l}\text { Walking and } \\
\text { jogging }\end{array}$ \\
\hline King 1988b & 1988 & Workplace & 51 & 51 & 40 to 60 & $\begin{array}{l}\text { Walking and } \\
\text { jogging }\end{array}$ \\
\hline King 1991 & 1991 & Community & 357 & 55 & 50 to 65 & $\begin{array}{l}\text { Group or } \\
\text { home based } \\
\text { walking/jogging } \\
\text { activities }\end{array}$ \\
\hline Lombard 1995 & 1995 & University & 135 & 2.2 & 21 to 63 & Walking \\
\hline Stevens1998 & 1998 & $\begin{array}{l}\text { Primary Health } \\
\text { Care }\end{array}$ & 714 & 42 & 45 to 74 & $\begin{array}{l}\text { Build on present } \\
\text { physical activities }\end{array}$ \\
\hline Goldstein 1999 & 1999 & $\begin{array}{l}\text { Primary Health } \\
\text { Care }\end{array}$ & 355 & 35 & $50+$ & $\begin{array}{l}\text { Choice of moderate } \\
\text { or vigorous physical } \\
\text { activity }\end{array}$ \\
\hline Harland 1999 & 1999 & $\begin{array}{l}\text { Primary Health } \\
\text { Care }\end{array}$ & 520 & 41.5 & 40 to 64 & $\begin{array}{l}\text { Choice of safe and } \\
\text { effective physical } \\
\text { activity }\end{array}$ \\
\hline Calfas 2000 & 2000 & University & 338 & 45.8 & 18 to 29 & $\begin{array}{l}\text { Moderate or } \\
\text { vigorous physical } \\
\text { activity plus } \\
\text { strength and } \\
\text { flexibility activities }\end{array}$ \\
\hline Norris 2000 & 2000 & $\begin{array}{l}\text { Primary Health } \\
\text { Care }\end{array}$ & 847 & 47.9 & $30+$ & $\begin{array}{l}\text { Moderate physical } \\
\text { activity }\end{array}$ \\
\hline Smith 2000 & 2000 & $\begin{array}{l}\text { Primary Health } \\
\text { Care }\end{array}$ & 1142 & 39.5 & 25 to 65 & $\begin{array}{l}\text { Physical activity } \\
\text { prescribed } \\
\text { by medical } \\
\text { practitioner }\end{array}$ \\
\hline $\begin{array}{l}\text { Simons-Morton } \\
\text { 2001a }\end{array}$ & 2001 & $\begin{array}{l}\text { Primary Health } \\
\text { Care }\end{array}$ & 479 & 100 & 35 to 75 & $\begin{array}{l}\text { Choice of moderate } \\
\text { or vigorous physical } \\
\text { activity }\end{array}$ \\
\hline $\begin{array}{l}\text { Simons- } \\
\text { Morton2001b }\end{array}$ & 2001 & $\begin{array}{l}\text { Primary Health } \\
\text { Care }\end{array}$ & 395 & 0 & 35 to 75 & $\begin{array}{l}\text { Choice of moderate } \\
\text { or vigorous physical } \\
\text { activity }\end{array}$ \\
\hline
\end{tabular}

Interventions for promoting physical activity (Review) 
Table 07. Descriptive data for review studies (Continued)

\begin{tabular}{|c|c|c|c|c|c|c|}
\hline Author & Publication year & Setting & No. randomised & $\%$ Male & Age range & $\begin{array}{l}\text { Authors' } \\
\text { description }\end{array}$ \\
\hline Stewart 2001 & 2001 & $\begin{array}{l}\text { Primary Health } \\
\text { Care }\end{array}$ & 173 & 34 & 65 to 95 & $\begin{array}{l}\text { Moderate physical } \\
\text { activity }\end{array}$ \\
\hline SSCT $2000^{*}$ & $2000 / 2003$ & Community & 65 & 46.1 & 60 to 81 & $\begin{array}{l}\text { Group based } \\
\text { endurance and } \\
\text { resistance training }\end{array}$ \\
\hline Dubbert 2002 & 2002 & $\begin{array}{l}\text { Primary Health } \\
\text { Care }\end{array}$ & 212 & 99 & 60 to 80 & Walking \\
\hline Green 2002 & 2002 & $\begin{array}{l}\text { Primary Health } \\
\text { Care }\end{array}$ & 316 & 47.5 & 20 to 64 & $\begin{array}{l}\text { Moderate physical } \\
\text { activity }\end{array}$ \\
\hline Hillsdon 2002 & 2002 & $\begin{array}{l}\text { Primary Health } \\
\text { Care }\end{array}$ & 1658 & 48.9 & 45 to 64 & $\begin{array}{l}\text { Choice of physical } \\
\text { activity or walking }\end{array}$ \\
\hline Lamb 2002 & 2002 & $\begin{array}{l}\text { Primary Health } \\
\text { Care }\end{array}$ & 260 & 48.8 & 40 to 70 & $\begin{array}{l}\text { Moderate intensity } \\
\text { physical activity } \\
\text { and walking }\end{array}$ \\
\hline Pinto 2002 & 2002 & $\begin{array}{l}\text { Primary Health } \\
\text { Care }\end{array}$ & 298 & 28 & $25+$ & $\begin{array}{l}\text { Moderate physical } \\
\text { activity }\end{array}$ \\
\hline Resnick 2002 & 2002 & Community & 20 & 0 & 84 to 92 & $\begin{array}{l}\text { Group based } \\
\text { or home based } \\
\text { walking }\end{array}$ \\
\hline Elley 2003 & 2003 & $\begin{array}{l}\text { Primary Health } \\
\text { Care }\end{array}$ & 878 & 33.5 & 40 to 79 & $\begin{array}{l}\text { Moderate physical } \\
\text { activity or walking }\end{array}$ \\
\hline Inoue 2003 & 2003 & Community & 86 & 0 & 47 to 68 & $\begin{array}{l}\text { Moderate physical } \\
\text { activity after group } \\
\text { programme }\end{array}$ \\
\hline Marshall 2003 & 2003 & Community & 462 & 42.5 & 40 to 60 & $\begin{array}{l}\text { Moderate physical } \\
\text { activity }\end{array}$ \\
\hline Petrella 2003 & 2003 & $\begin{array}{l}\text { Primary Health } \\
\text { Care }\end{array}$ & 284 & 52 & $65+$ & $\begin{array}{l}\text { Moderate physical } \\
\text { activity }\end{array}$ \\
\hline Marshall 2004 & 2004 & Community & 719 & 36 & Mean 43 & $\begin{array}{l}\text { Moderate physical } \\
\text { activity }\end{array}$ \\
\hline
\end{tabular}

*Same study with different outcome data (Tsuji VO2: Fujita - self reported physical activity) 
Table 08. Participation numbers in study recruitment, randomisation and follow up

\begin{tabular}{|c|c|c|c|c|c|c|}
\hline Study ID & $\begin{array}{l}\text { Potentially } \\
\text { eligible }\end{array}$ & Eligible (b) & Randomised (c) & Complete (d) & $\begin{array}{l}\% \text { com- } \\
\text { plete/eligible }\end{array}$ & $\begin{array}{l}\text { \% lost to follow } \\
\text { up }\end{array}$ \\
\hline Reid 1979 & Not stated & 146 & 124 & 34 & 23.2 & 72.5 \\
\hline Kriska 1986 & Not stated & 229 & 229 & 229 & 100 & 8.7 \\
\hline $\begin{array}{l}\text { Cunningham } \\
1987\end{array}$ & Not stated & 224 & 224 & 200 & 89.2 & 10.7 \\
\hline Juneau 1987 & Not stated & 126 & 120 & 113 & 89.6 & 5.8 \\
\hline King 1988a & Not stated & Not stated & 52 & 47 & Not available & 9.6 \\
\hline King 1988b & Not stated & Not stated & 51 & 48 & Not available & 5.8 \\
\hline King 1991 & 3117 & 1755 & 357 & 300 & 17.1 & 15.9 \\
\hline Lombard 1995 & $\begin{array}{l}\text { Approximately } \\
5000\end{array}$ & 135 & 135 & 135 & 100 & 0 \\
\hline Stevens 1998 & 2253 & 827 & 714 & 415 & 50.1 & 41.8 \\
\hline Goldstein 1999 & 2145 & 444 & 355 & 312 & 70.2 & 12.1 \\
\hline Harland 1999 & 2974 & 734 & 520 & 442 & 60.2 & 15.0 \\
\hline Calfas 2000 & Not stated & Not stated & 338 & $\begin{array}{l}315 \text { (data } \\
\text { provided by } \\
\text { study authors) }\end{array}$ & Not available & 6.8 \\
\hline Norris 2000 & 1920 & 985 & 847 & 812 & 82.4 & 4.1 \\
\hline Smith 2000 & 2097 & 1214 & 1142 & 1101 & 90.6 & 17.1 \\
\hline $\begin{array}{l}\text { Simons-Morton } \\
\text { 2001a }\end{array}$ & 3910 & NS & 479 & $\begin{array}{l}451 \text { - Self- } \\
\text { reported } \\
\text { physical activity, } \\
396 \text { - Cardio- } \\
\text { vascular fitness } \\
\text { (data provided } \\
\text { by study } \\
\text { authors) }\end{array}$ & Not available & $\begin{array}{l}5.8 \text { - Self- } \\
\text { reported } \\
\text { physical activity, } \\
17.3 \text { - Cardio- } \\
\text { vascular fitness }\end{array}$ \\
\hline $\begin{array}{l}\text { Simons- } \\
\text { Morton2001b }\end{array}$ & 3910 & NS & 395 & $\begin{array}{l}349 \text { - Self- } \\
\text { reported } \\
\text { physical activity, } \\
302 \text { - Cardio- } \\
\text { vascular fitness } \\
\text { (data provided } \\
\text { by study } \\
\text { authors) }\end{array}$ & Not available & $\begin{array}{l}11.6 \text { - Self- } \\
\text { reported } \\
\text { physical activity, } \\
23.5 \text { - Cardio- } \\
\text { vascular fitness }\end{array}$ \\
\hline Stewart 2001 & 1381 & 1053 & 173 & 164 & 15.5 & 5.0 \\
\hline SSCT 2000 & 322 & 209 & 65 & 64 & 30.6 & 1.5 \\
\hline Dubbert 2002 & 576 & 475 & 212 & 181 & 38.1 & 14.6 \\
\hline
\end{tabular}


Table 08. Participation numbers in study recruitment, randomisation and follow up (Continued)

\begin{tabular}{|c|c|c|c|c|c|c|}
\hline Study ID & $\begin{array}{l}\text { Potentially } \\
\text { eligible }\end{array}$ & Eligible (b) & Randomised (c) & Complete (d) & $\begin{array}{l}\% \text { com- } \\
\text { plete/eligible }\end{array}$ & $\begin{array}{l}\% \text { lost to follow } \\
\text { up }\end{array}$ \\
\hline Green 2002 & 1330 & 361 & 316 & 256 & 70.9 & 18.9 \\
\hline Hillsdon 2002 & 5797 & 1658 & 1658 & 674 & 40.6 & 0.1 \\
\hline Lamb 2002 & -2000 & 438 & 260 & 260 & 59.3 & 0 \\
\hline Pinto 2002 & 1738 & 609 & 298 & 238 & 39.0 & 18.4 \\
\hline Resnick 2002 & 120 & Not stated & 20 & 17 & Not stated & 15 \\
\hline Elley 2003 & 2984 & 1364 & 878 & 878 & 64.3 & 0 \\
\hline Inoue 2003 & 376 & 156 & 86 & 84 & 53.8 & 2.3 \\
\hline Marshall 2003 & 927 & 738 & 462 & 462 & 62.6 & 0 \\
\hline Petrella 2003 & 320 & 284 & 284 & 284 & 100 & 0 \\
\hline \multirow[t]{2}{*}{ Marshall 2004} & 1185 & 719 & 719 & 622 & 86.5 & 0 \\
\hline & $\begin{array}{l}\text { (a) Number of } \\
\text { people contacted } \\
\text { to determine } \\
\text { potential } \\
\text { eligibility }\end{array}$ & $\begin{array}{l}\text { (b) Number } \\
\text { identified as } \\
\text { eligible for study } \\
\text { - the number of } \\
\text { participants who } \\
\text { were assessed } \\
\text { as eligible for } \\
\text { randomisation } \\
\text { into study }\end{array}$ & $\begin{array}{l}\text { (c) Number } \\
\text { of people } \\
\text { randomised - } \\
\text { Number eligible } \\
\text { minus refusals, } \\
\text { excluded on } \\
\text { medical grounds } \\
\text { or failed to } \\
\text { attend for } \\
\text { randomisation }\end{array}$ & $\begin{array}{l}\text { (d) Number } \\
\text { with complete } \\
\text { data set at } \\
\text { final outcome } \\
\text { measure }\end{array}$ & $\begin{array}{l}\text { (e) \% Number } \\
\text { of participants } \\
\text { with final } \\
\text { outcome } \\
\text { measure / } \\
\text { Numbers } \\
\text { identified as } \\
\text { eligible for study }\end{array}$ & \\
\hline
\end{tabular}

Table 09. Characteristics of study type and intensity of intervention and follow up

\begin{tabular}{|c|c|c|c|c|c|}
\hline $\begin{array}{l}\text { Study ID \& } \\
\text { Author }\end{array}$ & $\begin{array}{l}\text { Programme } \\
\text { direction }\end{array}$ & Supervision & $\begin{array}{l}\text { Rate of } \\
\text { intervention }\end{array}$ & Rate of Follow Up & $\begin{array}{l}\text { Contact at Follow } \\
\text { up }\end{array}$ \\
\hline Reid 1979 & $\begin{array}{l}\mathrm{P} \text { - prescribed by } \\
\text { professional only }\end{array}$ & $\begin{array}{l}\text { US - physical } \\
\text { activity programme } \\
\text { was unstructured } \\
\text { and performed } \\
\text { independently by } \\
\text { the participant }\end{array}$ & High $-3+$ occasions & $\begin{array}{l}\text { High } 3+\text { occasions } \\
\text { between week } \\
\text { five and outcome } \\
\text { measure. }\end{array}$ & $\begin{array}{l}\text { Mixture of postal, } \\
\text { telephone or face- } \\
\text { to-face }\end{array}$ \\
\hline Kriska 1986 & $\begin{array}{l}\mathrm{P} \text { - prescribed by } \\
\text { professional only }\end{array}$ & $\begin{array}{l}\text { Mixed - physical } \\
\text { activity programme } \\
\text { was structured (S) } \\
\text { and unstructured } \\
\text { (US) }\end{array}$ & High - 3+ occasions & $\begin{array}{l}\text { High } 3+\text { occasions } \\
\text { between week } \\
\text { five and outcome } \\
\text { measure. }\end{array}$ & $\begin{array}{l}\text { Mixture of postal, } \\
\text { telephone or face- } \\
\text { to-face }\end{array}$ \\
\hline Cunningham 1987 & $\begin{array}{l}\mathrm{P} \text { - prescribed by } \\
\text { professional only }\end{array}$ & $\begin{array}{l}\text { Mixed - physical } \\
\text { activity programme } \\
\text { was structured }(S)\end{array}$ & High $-3+$ occasions & $\begin{array}{l}\text { High } 3+\text { occasions } \\
\text { between week } \\
\text { five and outcome }\end{array}$ & Face-to-face \\
\hline
\end{tabular}


Table 09. Characteristics of study type and intensity of intervention and follow up (Continued)

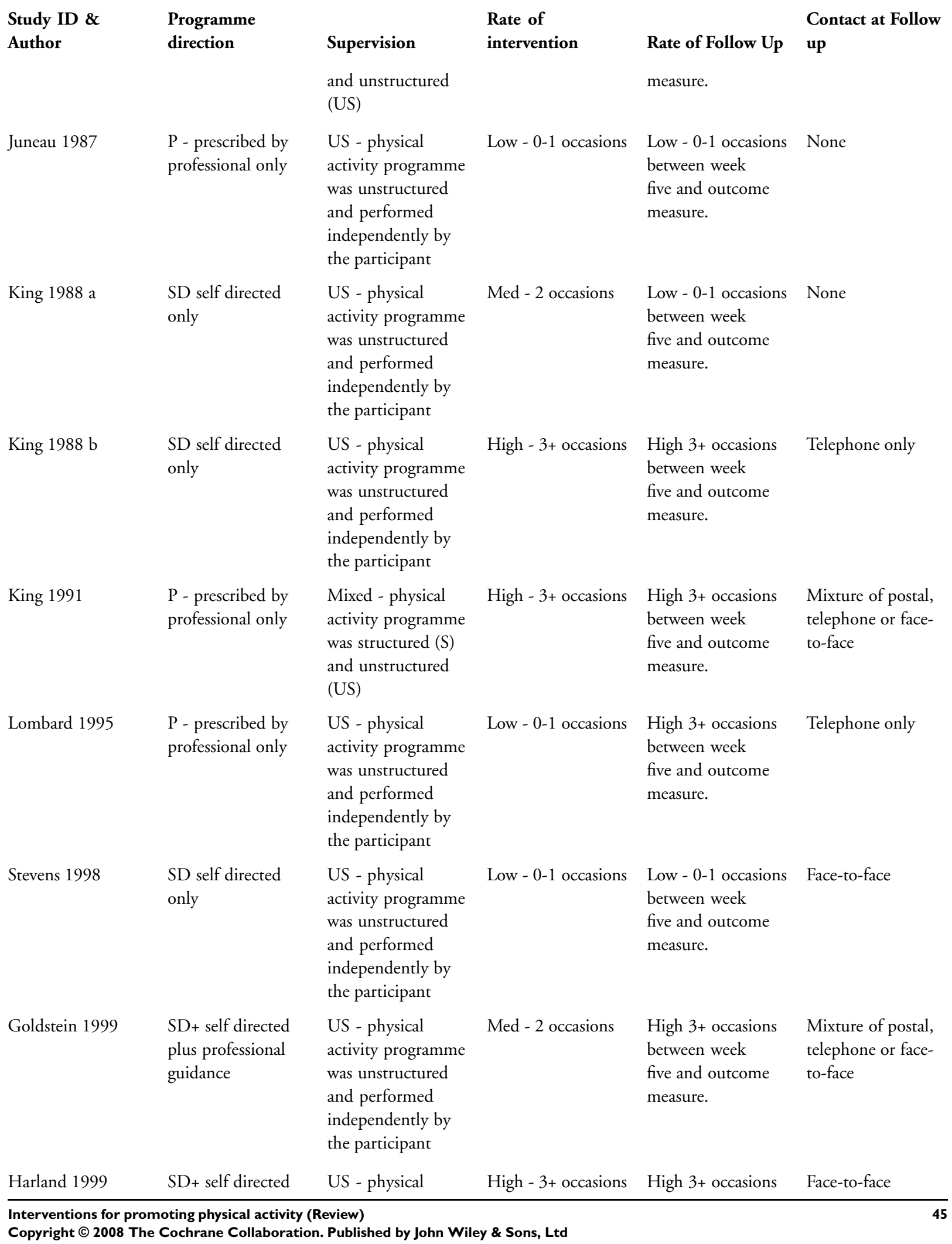


Table 09. Characteristics of study type and intensity of intervention and follow up (Continued)

\begin{tabular}{|c|c|c|c|c|c|}
\hline $\begin{array}{l}\text { Study ID \& } \\
\text { Author }\end{array}$ & $\begin{array}{l}\text { Programme } \\
\text { direction }\end{array}$ & Supervision & $\begin{array}{l}\text { Rate of } \\
\text { intervention }\end{array}$ & Rate of Follow Up & $\begin{array}{l}\text { Contact at Follow } \\
\text { up }\end{array}$ \\
\hline & $\begin{array}{l}\text { plus professional } \\
\text { guidance }\end{array}$ & $\begin{array}{l}\text { activity programme } \\
\text { was unstructured } \\
\text { and performed } \\
\text { independently by } \\
\text { the participant }\end{array}$ & & $\begin{array}{l}\text { between week } \\
\text { five and outcome } \\
\text { measure. }\end{array}$ & \\
\hline Calfas 2000 & $\begin{array}{l}\text { SD+ self directed } \\
\text { plus professional } \\
\text { guidance }\end{array}$ & $\begin{array}{l}\text { US - physical } \\
\text { activity programme } \\
\text { was unstructured } \\
\text { and performed } \\
\text { independently by } \\
\text { the participant }\end{array}$ & High $-3+$ occasions & $\begin{array}{l}\text { High } 3+\text { occasions } \\
\text { between week } \\
\text { five and outcome } \\
\text { measure. }\end{array}$ & $\begin{array}{l}\text { Mixture of postal, } \\
\text { telephone or face- } \\
\text { to-face }\end{array}$ \\
\hline Norris 2000 & $\begin{array}{l}\text { SD+ self directed } \\
\text { plus professional } \\
\text { guidance }\end{array}$ & $\begin{array}{l}\text { US - physical } \\
\text { activity programme } \\
\text { was unstructured } \\
\text { and performed } \\
\text { independently by } \\
\text { the participant }\end{array}$ & High $-3+$ occasions & $\begin{array}{l}\text { High } 3+\text { occasions } \\
\text { between week } \\
\text { five and outcome } \\
\text { measure. }\end{array}$ & $\begin{array}{l}\text { Mixture of postal, } \\
\text { telephone or face- } \\
\text { to-face }\end{array}$ \\
\hline Smith 2000 & $\begin{array}{l}\mathrm{P} \text { - prescribed by } \\
\text { professional only }\end{array}$ & $\begin{array}{l}\text { US - physical } \\
\text { activity programme } \\
\text { was unstructured } \\
\text { and performed } \\
\text { independently by } \\
\text { the participant }\end{array}$ & Med - 2 occasions & $\begin{array}{l}\text { Low - } 0-1 \text { occasions } \\
\text { between week } \\
\text { five and outcome } \\
\text { measure. }\end{array}$ & $\begin{array}{l}\text { Mixture of postal, } \\
\text { telephone or face- } \\
\text { to-face }\end{array}$ \\
\hline $\begin{array}{l}\text { Simons-Morton } \\
\text { 2001a }\end{array}$ & $\begin{array}{l}\text { SD+ self directed } \\
\text { plus professional } \\
\text { guidance }\end{array}$ & $\begin{array}{l}\text { US - physical } \\
\text { activity programme } \\
\text { was unstructured } \\
\text { and performed } \\
\text { independently by } \\
\text { the participant }\end{array}$ & High $-3+$ occasions & $\begin{array}{l}\text { High } 3+\text { occasions } \\
\text { between week } \\
\text { five and outcome } \\
\text { measure. }\end{array}$ & $\begin{array}{l}\text { Mixture of postal, } \\
\text { telephone or face- } \\
\text { to-face }\end{array}$ \\
\hline $\begin{array}{l}\text { Simons-Morton } \\
2001 \mathrm{~b}\end{array}$ & $\begin{array}{l}\text { SD+ self directed } \\
\text { plus professional } \\
\text { guidance }\end{array}$ & $\begin{array}{l}\text { US - physical } \\
\text { activity programme } \\
\text { was unstructured } \\
\text { and performed } \\
\text { independently by } \\
\text { the participant }\end{array}$ & High $-3+$ occasions & $\begin{array}{l}\text { High } 3+\text { occasions } \\
\text { between week } \\
\text { five and outcome } \\
\text { measure. }\end{array}$ & $\begin{array}{l}\text { Mixture of postal, } \\
\text { telephone or face- } \\
\text { to-face }\end{array}$ \\
\hline Stewart 2001 & $\begin{array}{l}\text { SD+ self directed } \\
\text { plus professional } \\
\text { guidance }\end{array}$ & $\begin{array}{l}\text { US - physical } \\
\text { activity programme } \\
\text { was unstructured } \\
\text { and performed } \\
\text { independently by } \\
\text { the participant }\end{array}$ & High $-3+$ occasions & $\begin{array}{l}\text { High } 3+\text { occasions } \\
\text { between week } \\
\text { five and outcome } \\
\text { measure. }\end{array}$ & $\begin{array}{l}\text { Mixture of postal, } \\
\text { telephone or face- } \\
\text { to-face }\end{array}$ \\
\hline SSCT 2000 & $\begin{array}{l}\mathrm{P} \text { - prescribed by } \\
\text { professional only }\end{array}$ & $\begin{array}{l}\mathrm{S} \text { - physical activity } \\
\text { programme was } \\
\text { structured and } \\
\text { supervised by }\end{array}$ & High $-3+$ occasions & $\begin{array}{l}\text { High } 3+\text { occasions } \\
\text { between week } \\
\text { five and outcome } \\
\text { measure. }\end{array}$ & $\begin{array}{l}\text { Mixture of postal, } \\
\text { telephone or face- } \\
\text { to-face }\end{array}$ \\
\hline
\end{tabular}


Table 09. Characteristics of study type and intensity of intervention and follow up (Continued)

\section{Study ID \& Author}

Dubbert 2002

Green 2002

Hillsdon 2002

Lamb 2002

Pinto 2002

Resnick 2002

Elley 2003

Inoue 2003

\section{Programme direction}

SD - self directed
only

SD - self directed only

SD - self directed only

$\mathrm{SD}+$ self directed plus professional guidance

SD - self directed
only

P - prescribed by professional only

$\mathrm{SD}+$ self directed plus professional guidance

SD + self directed plus professional guidance
Supervision

professional

US - physical activity programme was unstructured and performed independently by the participant

US - physical activity programme was unstructured and performed independently by the participant

US - physical activity programme was unstructured and performed independently by the participant

Mixed - physical activity programme was structured (S) and unstructured (US)

US - physical activity programme was unstructured and performed independently by the participant

Mixed - physical activity programme was structured (S) and unstructured (US)

US - physical activity programme was unstructured and performed independently by the participant

Mixed - physical activity programme was structured (S)
Rate of

intervention

High - 3+ occasions

High 3+ occasions between week five and outcome measure.

High - 3+ occasions

High 3+ occasions between week five and outcome measure.

Low - 0-1 occasions

High 3+ occasions between week five and outcome measure.

Low - 0-1 occasions

Low - 0-1 occasions between week five and outcome measure.

High - 3+ occasions

High 3+ occasions between week five and outcome measure.

High - 3+ occasions

High 3+ occasions between week five and outcome measure.

Low - 0-1 occasions Low - 0-1 occasions between week five and outcome measure.

High - 3+ occasions between week five and outcome

\section{Contact at Follow} up

Mixture of postal, telephone or faceto-face

Telephone only

Telephone only

Mixture of postal, telephone or faceto-face

Mixture of postal, telephone or faceto-face

Mixture of postal, telephone or faceto-face

Mixture of postal, telephone or faceto-face

Postal only

Postal only


Table 09. Characteristics of study type and intensity of intervention and follow up (Continued)

\begin{tabular}{|c|c|c|c|c|c|}
\hline $\begin{array}{l}\text { Study ID \& } \\
\text { Author }\end{array}$ & $\begin{array}{l}\text { Programme } \\
\text { direction }\end{array}$ & Supervision & $\begin{array}{l}\text { Rate of } \\
\text { intervention }\end{array}$ & Rate of Follow Up & $\begin{array}{l}\text { Contact at Follow } \\
\text { up }\end{array}$ \\
\hline & & $\begin{array}{l}\text { and unstructured } \\
\text { (US) }\end{array}$ & & measure. & \\
\hline Marshall 2003 & $\begin{array}{l}\text { SD - self directed } \\
\text { only }\end{array}$ & $\begin{array}{l}\text { US - physical } \\
\text { activity programme } \\
\text { was unstructured } \\
\text { and performed } \\
\text { independently by } \\
\text { the participant }\end{array}$ & Low - 0-1 occasions & $\begin{array}{l}\text { Low - } 0-1 \text { occasions } \\
\text { between week } \\
\text { five and outcome } \\
\text { measure. }\end{array}$ & None \\
\hline Petrella 2003 & $\begin{array}{l}\text { SD - self directed } \\
\text { only }\end{array}$ & $\begin{array}{l}\text { US - physical } \\
\text { activity programme } \\
\text { was unstructured } \\
\text { and performed } \\
\text { independently by } \\
\text { the participant }\end{array}$ & Low - $0-1$ occasions & $\begin{array}{l}\text { Low - } 0-1 \text { occasions } \\
\text { between week } \\
\text { five and outcome } \\
\text { measure. }\end{array}$ & Face-to-face \\
\hline \multirow[t]{2}{*}{ Marshall 2004} & $\begin{array}{l}\text { SD - self directed } \\
\text { only }\end{array}$ & $\begin{array}{l}\text { US - physical } \\
\text { activity programme } \\
\text { was unstructured } \\
\text { and performed } \\
\text { independently by } \\
\text { the participant }\end{array}$ & Low - $0-1$ occasions & $\begin{array}{l}\text { Low - } 0-1 \text { occasions } \\
\text { between week } \\
\text { five and outcome } \\
\text { measure. }\end{array}$ & None \\
\hline & $\begin{array}{l}\text { (a) Nature of } \\
\text { direction of the } \\
\text { intervention }\end{array}$ & $\begin{array}{l}\text { (b) Degree of } \\
\text { programme } \\
\text { supervision - S - } \\
\text { physical activity } \\
\text { programme was } \\
\text { structured and } \\
\text { supervised by } \\
\text { professional, US } \\
\text { - physical activity } \\
\text { programme was } \\
\text { unstructured } \\
\text { and performed } \\
\text { independently by } \\
\text { the participant }\end{array}$ & $\begin{array}{l}\text { (c) Frequency } \\
\text { of intervention } \\
\text { occasions in first } \\
\text { four weeks post } \\
\text { baseline. }\end{array}$ & $\begin{array}{l}\text { (d) Frequency of } \\
\text { follow up contacts. }\end{array}$ & $\begin{array}{l}\text { (e) Type of follow } \\
\text { up contacts }\end{array}$ \\
\hline
\end{tabular}

Table 10. Characteristics of study control groups and number of study arms

$\begin{array}{llll}\text { Study ID } & \text { No. study arms (a) } & \text { Description (b) } & \text { Type of control (c) } \\ \text { Reid } 1979 & 2 & \text { Written advice } & \text { Comparison control } \\ \text { Kriska } 1986 & 2 & \text { Baseline assessment only } & \text { No contact } \\ \text { Cunningham } 1987 & 2 & \text { Continue usual physical activity } & \text { No contact } \\ \text { Juneau } 1987 & 2 & \text { Daily physical activity logs } & \text { Comparison control }\end{array}$

Interventions for promoting physical activity (Review)

Copyright ( 2008 The Cochrane Collaboration. Published by John Wiley \& Sons, Ltd 
Table 10. Characteristics of study control groups and number of study arms (Continued)

\begin{tabular}{|c|c|c|c|}
\hline Study ID & No. study arms (a) & Description (b) & Type of control (c) \\
\hline King 1988a & 2 & Weekly exercise monitoring & Comparison control \\
\hline King 1988b & 2 & $\begin{array}{l}\text { Self monitoring materials and } \\
\text { pulse monitor }\end{array}$ & Comparison control \\
\hline King 1991 & 4 & $\begin{array}{l}\text { Asked not to change physical } \\
\text { activity }\end{array}$ & No contact \\
\hline Lombard 1995 & 2 & Written information & Comparison control \\
\hline Stevens 1998 & 2 & Written information & Comparison control \\
\hline Goldstein 1999 & 2 & Usual care & Attention control \\
\hline Harland 1999 & 5 & Health check & Attention control \\
\hline Calfas 2000 & 2 & General health lectures & Attention control \\
\hline Norris 2000 & 3 & Usual care & No contact \\
\hline Smith 2000 & 3 & Usual care & No contact \\
\hline Simons-Morton 2001a & 3 & $\begin{array}{l}\text { Advice to exercise from physician } \\
\& \text { health educator }\end{array}$ & Comparison control \\
\hline Simons-Morton 2001b & 3 & $\begin{array}{l}\text { Advice to exercise from physician } \\
\& \text { health educator }\end{array}$ & Comparison control \\
\hline Stewart 2001 & 2 & Wait list & No contact \\
\hline SSCT 2000 & 2 & $\begin{array}{l}\text { Attend weekly lecture and indoor } \\
\text { games }\end{array}$ & Attention control \\
\hline Dubbert 2002 & 3 & Wait list & Comparison control \\
\hline Green 2002 & 2 & Self help materials only & Comparison control \\
\hline Hillsdon 2002 & 3 & Wait list & Attention control \\
\hline Lamb 2002 & 2 & $\begin{array}{l}\text { Group seminar and advice to } \\
\text { exercise }\end{array}$ & Comparison control \\
\hline Pinto 2002 & 2 & Computer-based phone calls & Attention control \\
\hline Resnick 2002 & 2 & Routine care & Attention control \\
\hline Elley 2003 & 2 & Usual care and wait list & Attention control \\
\hline Inoue 2003 & 2 & Baseline assessments only & No contact \\
\hline Marshall 2003 & 2 & Assessments only & Attention control \\
\hline Petrella 2003 & 2 & $\begin{array}{l}\text { Exercise counselling, advice and } \\
\text { record their exercise weekly in a } \\
\text { diary }\end{array}$ & Comparison control \\
\hline \multirow[t]{2}{*}{ Marshall 2004} & 2 & Assessments only & Attention control \\
\hline & $\begin{array}{l}\text { (a) Number of study arms - This } \\
\text { figure is a sum of the number of }\end{array}$ & (b) Description of control group & $\begin{array}{l}\text { (c) Type of control group - No } \\
\text { contact - Wait list, baseline }\end{array}$ \\
\hline
\end{tabular}


Table 10. Characteristics of study control groups and number of study arms (Continued)

$\begin{array}{lll}\text { Study ID } & \text { No. study arms (a) } & \text { Type of control (c) } \\ \text { intervention arms plus control } & \text { Description (b) } & \text { assessment only, Attention control } \\ & \text { - Usual care, health check, health } \\ & \text { advice not physical activity } \\ & \text { specific, Comparison control - } \\ & \text { Written information, advice about } \\ & \text { physical activity, self monitoring } \\ & \text { materials }\end{array}$

Table 11. Outcome measure, SMD, 95\% CI for studies with continuous self-reported PA

\begin{tabular}{|c|c|c|c|c|c|}
\hline Study ID & Outcome measure & SMD & $95 \% \mathrm{CI}$ & Outcome direction & Study quality score \\
\hline Kriska 1986 & $\mathrm{Kcal} /$ week & 0.54 & 0.28 to 0.80 & + favours intervention & 1 \\
\hline Cunningham 1987 & $\begin{array}{l}\text { Mins/day vigorous } \\
\text { physical activity (>4.9 } \\
\text { METS) }\end{array}$ & 0.40 & 0.13 to 0.67 & + favours intervention & 0 \\
\hline King 1998a & $\begin{array}{l}\text { Exercise occasions per } \\
\text { month ( } 30 \text { Mins. per } \\
\text { session) }\end{array}$ & 0.64 & 0.05 to 1.23 & + favours intervention & 2 \\
\hline King 1988b & $\begin{array}{l}\text { Exercise occasions per } \\
\text { month ( } 30 \text { Mins. per } \\
\text { session) }\end{array}$ & 0.37 & -0.21 to 0.94 & 0 no effect & 2 \\
\hline Stevens 1998 & $\begin{array}{l}\text { Exercise occasions per } \\
\text { month (greater than } 20 \\
\text { Mins per session) }\end{array}$ & 0.84 & 0.68 to 0.99 & + favours intervention & 2 \\
\hline Goldstein 1999 & $\begin{array}{l}\text { Physical Activity Scale } \\
\text { for Elderly (PASE Scale) }\end{array}$ & 0.02 & -0.20 to 0.24 & 0 no effect & 0 \\
\hline Calfas 2000 & $\mathrm{Kcal} / \mathrm{kg} /$ week & 0.12 & -0.10 to 0.34 & 0 no effect & 1 \\
\hline Smith 2000 & Mins/week & 0.08 & -0.04 to 0.21 & 0 no effect & 3 \\
\hline Simons-Morton 2001a & $\mathrm{Kcal} / \mathrm{kg} /$ day & 0.18 & -0.02 to 0.38 & 0 no effect & 4 \\
\hline Simons-Morton 2001a & $\mathrm{Kcal} / \mathrm{kg} /$ day & 0.08 & -0.14 to 0.30 & 0 no effect & 4 \\
\hline Stewart 2001 & $\mathrm{Kcal} /$ day & 0.32 & 0.02 to 0.63 & + favours intervention & 3 \\
\hline SSCT 2000 & $\begin{array}{l}\text { Total daily energy } \\
\text { expenditure } \\
(\mathrm{kcal} / \mathrm{kg} / \text { day })\end{array}$ & 1.18 & 0.64 to 1.72 & + favours intervention & 1 \\
\hline Green 2002 & $\begin{array}{l}\text { Self reported physical } \\
\text { activity PACE score }\end{array}$ & 0.24 & 0.00 to 0.49 & 0 no effect & 3 \\
\hline Hillsdon 2002 & $\begin{array}{l}\text { Energy expenditure } \\
(\mathrm{kcal} / \mathrm{kg} / \text { week })\end{array}$ & 0.06 & -0.04 to 0.16 & 0 no effect & 3 \\
\hline Pinto 2002 & $\begin{array}{l}\text { Moderate intensity } \\
\text { physical activity } \\
\text { (kcal/week) }\end{array}$ & 0.06 & -0.19 to 0.32 & 0 no effect & 2 \\
\hline
\end{tabular}


Table 11. Outcome measure, SMD, 95\% CI for studies with continuous self-reported PA (Continued)

\begin{tabular}{|c|c|c|c|c|c|}
\hline Study ID & Outcome measure & SMD & $95 \% \mathrm{CI}$ & Outcome direction & Study quality score \\
\hline Resnick 2002 & Energy expenditure & 0.72 & -0.29 to 1.72 & 0 no effect & 0 \\
\hline Elley 2003 & $\begin{array}{l}\text { Energy expenditure } \\
(\mathrm{kcal} / \mathrm{kg} / \text { week })\end{array}$ & 0.19 & 0.06 to 0.32 & + favours intervention & 1 \\
\hline Inoue 2003 & $\begin{array}{l}\text { Moderate intensity } \\
\text { physical activity } \\
\text { (kcal/week) }\end{array}$ & 0.24 & -0.19 to 0.67 & 0 no effect & 1 \\
\hline \multirow[t]{2}{*}{ Marshall 2003} & $\begin{array}{l}\text { Total physical activity } \\
\text { (hrs/week) }\end{array}$ & 0.06 & -0.12 to 0.24 & 0 no effect & 2 \\
\hline & $\begin{array}{l}\text { METS = Energy cost } \\
\text { of physical activity } \\
\text { measured at cost of basal } \\
\text { metabolic rate. }\end{array}$ & & & & \\
\hline
\end{tabular}

Table 12. Outcome measure, OR, 95\% CI for studies with dichotomous physical activity

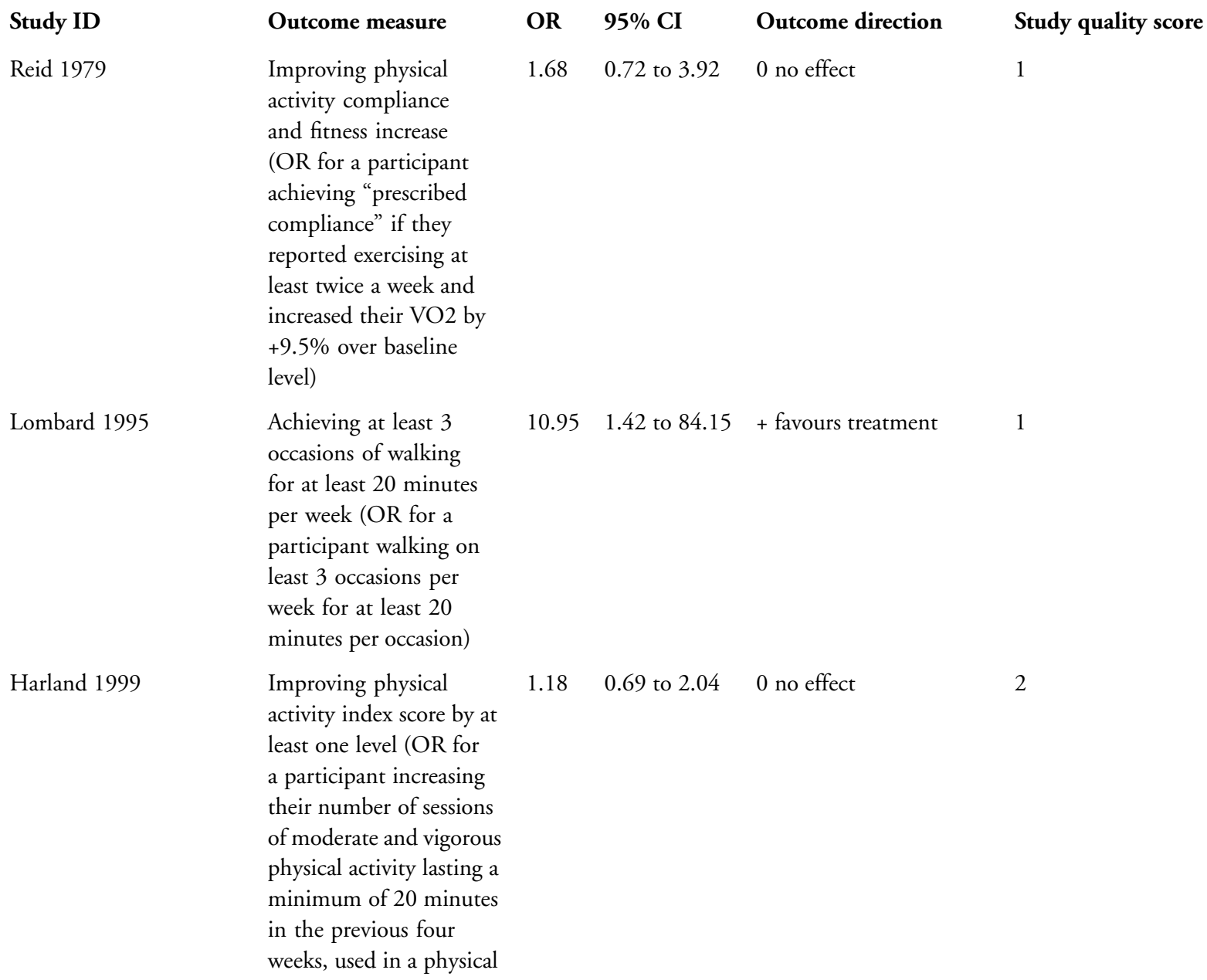

Harland 1999

Improving physical

$1.18 \quad 0.69$ to $2.04 \quad 0$ no effect

activity index score by at least one level (OR for a participant increasing their number of sessions of moderate and vigorous physical activity lasting a minimum of 20 minutes in the previous four weeks, used in a physical

10.951 .42 to 84.15 + favours treatment 1 
Table 12. Outcome measure, OR, 95\% CI for studies with dichotomous physical activity

(Continued)

Study ID

Norris 2000

Simons-Morton 2001a

Simons-Morton 2001b

Dubbert 2002

\section{Outcome measure}

activity index score)

Increasing physical activity by at least 30 minutes per week (OR for a participant increasing their level of any type of physical activity by at least 30 minutes per week compared to their baseline level)

Meeting CDC recommendation for physical activity (Odds ratio for a participant meeting 30 minutes of moderate to vigorous intensity physical activity (at least 3 METS) at least 5 days a week, 30 minutes of vigorous physical activity (at least 5 METS) at least 3 days a week, or at least $2 \mathrm{kcal} \cdot \mathrm{kg}-1 \cdot$ day- 1 in moderate to vigorous physical activity)

Meeting CDC recommendation for physical activity (Odds ratio for a participant meeting 30 minutes of moderate to vigorous intensity physical activity (at least 3 METS) at least 5 days a week, 30 minutes of vigorous physical activity (at least 5 METS) at least 3 days a week, or at least $2 \mathrm{kcal} \cdot \mathrm{kg}-1 \cdot$ day-1 in moderate to vigorous physical activity)

Achieving exercise adherence goal of walking $20 \mathrm{~min} 3$ days/week
OR $\quad 95 \%$ CI

Outcome direction

Study quality score

$0.79 \quad 0.60$ to $1.04 \quad 0$ no effect

2

1.63

0.98 to 2.71

0 no effect

4

$1.26 \quad 0.68$ to $2.34 \quad 0$ no effect

4 
Table 12. Outcome measure, OR, $95 \%$ CI for studies with dichotomous physical activity (Continued)

\begin{tabular}{|c|c|c|c|c|c|}
\hline Study ID & Outcome measure & OR & $95 \% \mathrm{CI}$ & Outcome direction & Study quality score \\
\hline Lamb 2002 & $\begin{array}{l}\text { Achieving more than } \\
120 \text { minutes per week } \\
\text { moderate physical } \\
\text { activity }\end{array}$ & 1.51 & 0.84 to 2.74 & 0 no effect & 3 \\
\hline Pinto 2002 & $\begin{array}{l}\text { Meeting CDC/ACSM } \\
\text { recommendation for } \\
\text { moderate physical } \\
\text { activity }\end{array}$ & 1.24 & 0.64 to 2.38 & 0 no effect & 2 \\
\hline \multirow[t]{2}{*}{ Marshall 2004} & $\begin{array}{l}\text { Achieving a sufficient } \\
\text { level of physical activity }\end{array}$ & 1.22 & 0.89 to 1.69 & 0 no effect & 1 \\
\hline & $\begin{array}{l}\mathrm{CDC}=\text { Centre for } \\
\text { disease control }\end{array}$ & & & & \\
\hline
\end{tabular}

Table 13. Outcome measure, SMD, $95 \%$ CI for studies with continuous cardio-respir fitness

$\begin{array}{llllll}\begin{array}{l}\text { Study ID } \\ \text { Cunningham 1987 }\end{array} & \text { Outcome measure } & \text { SMD } & \text { 95\% CI } & \text { Outcome direction } & \text { Study quality score } \\ \begin{array}{l}\text { Juneau 1987 } \\ \text { King 1988a }\end{array} & \text { VO2 } & 0.44 & 0.16 \text { to } 0.72 & \text { + favours treatment } & 0 \\ \begin{array}{l}\text { KO2 } \\ \text { King 1988b }\end{array} & 1.49 & 1.07 \text { to } 1.91 & \text { + favours treatment } & 0 \\ \text { King 1991 } & \text { VO2 } & -0.16 & -0.74 \text { to } 0.42 & 0 \text { no effect } & 2 \\ \text { Simons-Morton 2001a } & \text { VO2 } & 0.15 & -0.42 \text { to } 0.72 & 0 \text { no effect } & 2 \\ \text { Simons-Morton 2001b } & \text { VO2 } & 0.17 & -0.09 \text { to } 0.43 & 0 \text { no effect } & 3 \\ \text { SSCT 2000 } & \text { VO2 } & 0.14 & -0.07 \text { to } 0.35 & 0 \text { no effect } & 4 \\ \text { Dubbert 2002 } & \text { VO2 } & 0.47 & 0.23 \text { to } 0.71 & \text { + favours treatment } & 4 \\ \text { Lamb 2002 } & \text { VO2 } & 1.14 & 0.61 \text { to } 1.68 & \text { + favours treatment } & 1 \\ \text { Petrella 2003 } & \text { VO2 } & -0.06 & -0.37 \text { to } 0.25 & 0 \text { no effect } & 1\end{array}$

\section{A N A L Y S E S}

\section{Comparison 01. Pooled effects}

\begin{tabular}{|c|c|c|c|c|}
\hline Outcome title & $\begin{array}{l}\text { No. of } \\
\text { studies }\end{array}$ & $\begin{array}{c}\text { No. of } \\
\text { participants }\end{array}$ & Statistical method & Effect size \\
\hline $\begin{array}{l}01 \text { Studies with continuous data } \\
\text { for self-reported physical } \\
\text { activity }\end{array}$ & 19 & 7598 & $\begin{array}{l}\text { Standardised Mean Difference (Random) 95\% } \\
\text { CI }\end{array}$ & $0.28[0.15,0.41]$ \\
\hline $\begin{array}{l}02 \text { Studies with dichotomous } \\
\text { data for self-reported physical } \\
\text { activity }\end{array}$ & 10 & 3595 & Odds Ratio (Random) 95\% CI & $1.33[1.03,1.72]$ \\
\hline
\end{tabular}


03 Studies with continuous data

\section{Comparison 02. Sensitivity anaylsis}

\begin{tabular}{lcclcc} 
Outcome title & $\begin{array}{c}\text { No. of } \\
\text { studies }\end{array}$ & $\begin{array}{c}\text { No. of } \\
\text { participants }\end{array}$ & \multicolumn{1}{c}{ Statistical method } & Effect size \\
\hline $\begin{array}{l}\text { 01 Study quality - continuous } \\
\text { data for self-reported physical } \\
\text { activity }\end{array}$ & 19 & 7598 & $\begin{array}{l}\text { Standardised Mean Difference (Random) } 95 \% \\
\text { CI }\end{array}$ & $0.28[0.15,0.41]$ \\
$\begin{array}{l}02 \text { Study quality - dichotomous } \\
\text { data for self-reported physcial } \\
\text { activity }\end{array}$ & 10 & 3595 & Odds Ratio (Random) 95\% CI & $1.33[1.03,1.72]$ \\
$\begin{array}{l}03 \text { Study quality - continuous data } \\
\text { for cardio-respiratory fitness }\end{array}$ & 11 & 2195 & $\begin{array}{l}\text { Standardised Mean Difference (Random) } 95 \% \\
\text { CI }\end{array}$ & $0.52[0.14,0.90]$ \\
\hline
\end{tabular}

\section{Comparison 03. Sub group analysis}

\begin{tabular}{|c|c|c|c|c|}
\hline Outcome title & $\begin{array}{l}\text { No. of } \\
\text { studies }\end{array}$ & $\begin{array}{c}\text { No. of } \\
\text { participants }\end{array}$ & Statistical method & Effect size \\
\hline $\begin{array}{l}01 \text { Nature of direction - self- } \\
\text { reported physical activity }\end{array}$ & & & $\begin{array}{l}\text { Standardised Mean Difference (Random) 95\% } \\
\text { CI }\end{array}$ & Totals not selected \\
\hline $\begin{array}{l}02 \text { Nature of direction - cardio- } \\
\text { respiratory fitness }\end{array}$ & & & $\begin{array}{l}\text { Standardised Mean Difference (Random) 95\% } \\
\text { CI }\end{array}$ & Totals not selected \\
\hline $\begin{array}{l}03 \text { Frequency of intervention } \\
\text { occasions - self-reported } \\
\text { physical activity }\end{array}$ & & & $\begin{array}{l}\text { Standardised Mean Difference (Random) 95\% } \\
\text { CI }\end{array}$ & Totals not selected \\
\hline $\begin{array}{l}04 \text { Frequency of intervention } \\
\text { occasions - dichotomous data }\end{array}$ & & & Odds Ratio (Random) 95\% CI & Totals not selected \\
\hline $\begin{array}{l}05 \text { Frequency of intervention } \\
\text { occasions - cardio-respiratory } \\
\text { fitness }\end{array}$ & & & $\begin{array}{l}\text { Standardised Mean Difference (Random) 95\% } \\
\text { CI }\end{array}$ & Totals not selected \\
\hline $\begin{array}{l}06 \text { Frequency of follow-up - self- } \\
\text { reported physical activity }\end{array}$ & & & $\begin{array}{l}\text { Standardised Mean Difference (Random) 95\% } \\
\text { CI }\end{array}$ & Totals not selected \\
\hline $\begin{array}{l}07 \text { Frequency of follow-up - } \\
\text { cardio-respiratory fitness }\end{array}$ & & & $\begin{array}{l}\text { Standardised Mean Difference (Random) 95\% } \\
\text { CI }\end{array}$ & Totals not selected \\
\hline $\begin{array}{l}08 \text { Frequency of follow-up - } \\
\text { dichotomous data }\end{array}$ & & & Odds Ratio (Random) 95\% CI & Totals not selected \\
\hline $\begin{array}{l}09 \text { Degree of supervision - self- } \\
\text { reported physical activity }\end{array}$ & & & $\begin{array}{l}\text { Standardised Mean Difference (Random) 95\% } \\
\text { CI }\end{array}$ & Totals not selected \\
\hline $\begin{array}{l}10 \text { Degree of supervison - cardio- } \\
\text { respiratory fitness }\end{array}$ & & & $\begin{array}{l}\text { Standardised Mean Difference (Random) 95\% } \\
\text { CI }\end{array}$ & Totals not selected \\
\hline
\end{tabular}

\section{INDEX TERMS}

\section{Medical Subject Headings (MeSH)}

*Exercise; Health Promotion [*methods]; Physical Fitness; Randomized Controlled Trials as Topic

\section{MeSH check words}




\section{COVER SHEET}

Title

\section{Authors}

\section{Contribution of author(s)}

Interventions for promoting physical activity

Foster C, Hillsdon M, Thorogood M

Dr Foster was involved in:

Conceiving the review

Designing the review

Coordinating the review

Screening search results

Screening retrieved papers against inclusion criteria

Appraising quality of papers

Abstracting data from papers

Data management for the review

Entering data into RevMan

Analysis of data

Interpretation of data

Providing a methodological perspective

Providing a clinical perspective

Providing a policy perspective

Writing the review

Providing general advice on the review

Securing funding for the review

Performing previous work that was the foundation of current study.

Dr Hillsdon was involved in:

Conceiving the review

Designing the review

Coordinating the review

Data collection for the review

Developing search strategy

Undertaking searches

Screening search results

Organising retrieval of papers

Screening retrieved papers against inclusion criteria

Appraising quality of papers

Abstracting data from papers

Writing to authors of papers for additional information

Providing additional data about papers

Obtaining and screening data on unpublished studies

Data management for the review

Entering data into RevMan

Analysis of data

Interpretation of data

Providing a methodological perspective

Providing a clinical perspective

Providing a policy perspective

Writing the review

Providing general advice on the review

Securing funding for the review

Performing previous work that was the foundation of current study

Professor Thorogood was involved with:

Conceiving the review

Designing the review 


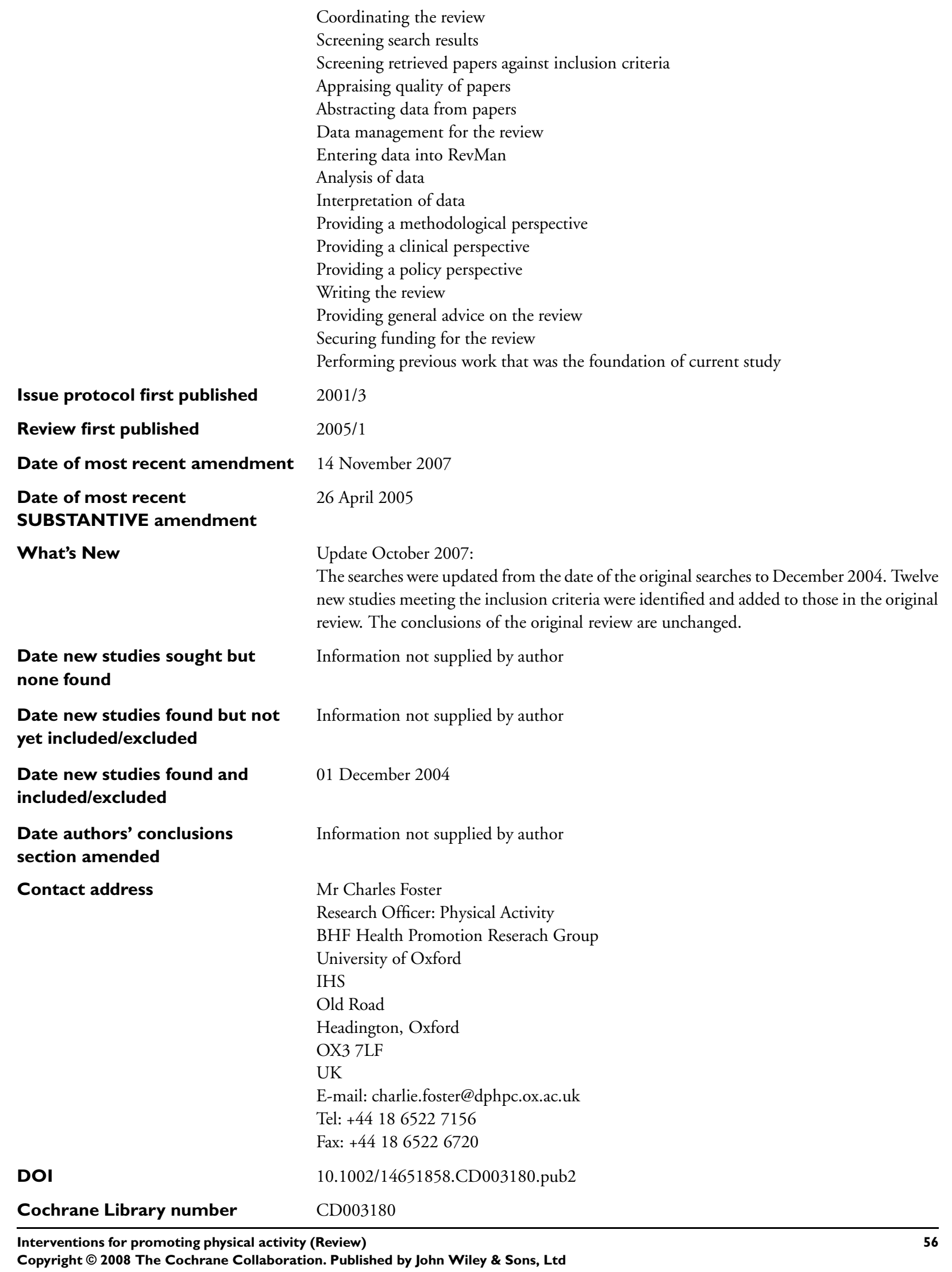


Editorial group

Editorial group code
Cochrane Heart Group

HM-VASC 


\section{GRAPHS ANDOTHER TABLES}

\section{Figure 0I. QUOROM statement}

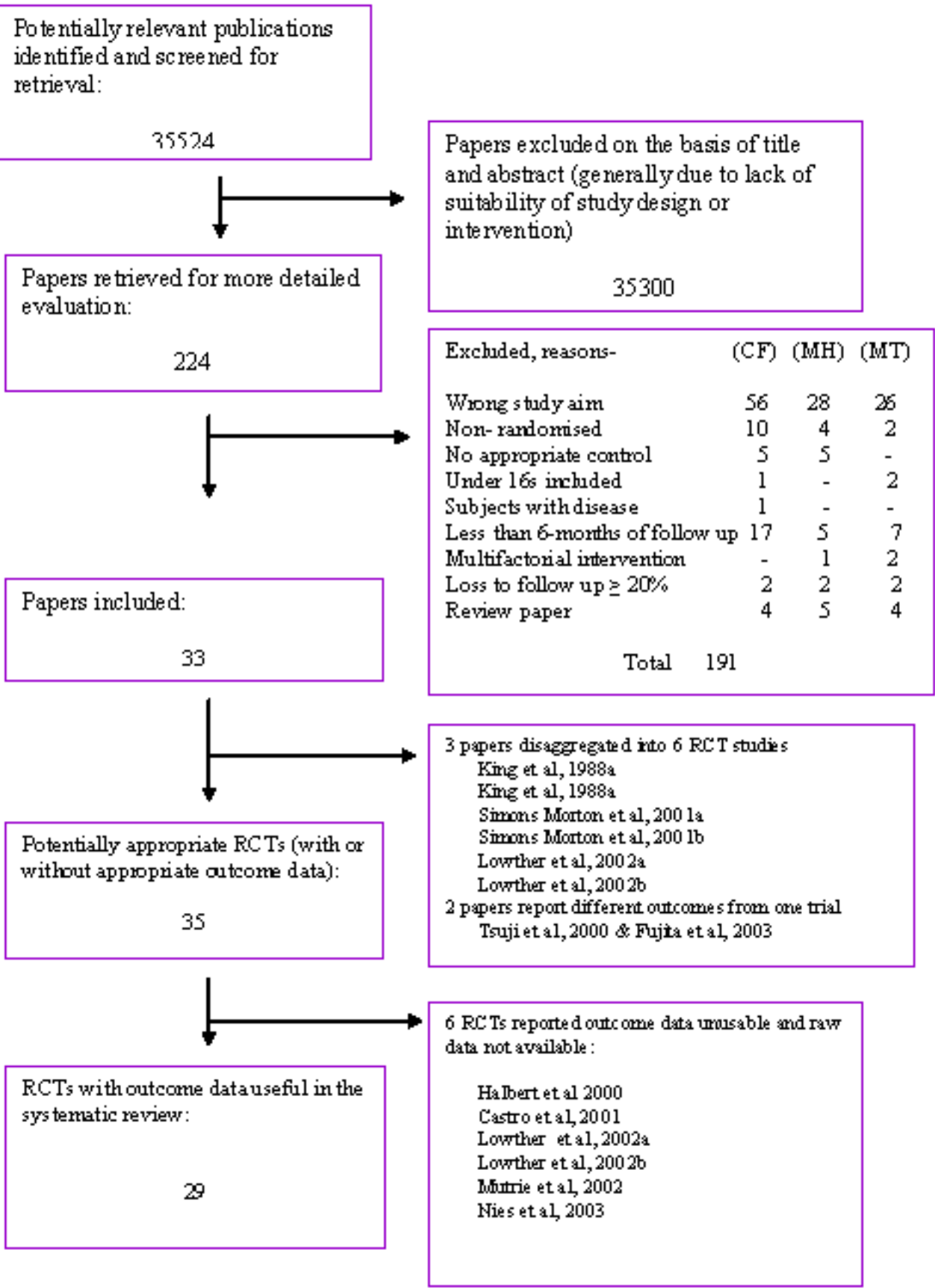




\section{Analysis 01.0I. Comparison 0I Pooled effects, Outcome 0I Studies with continuous data for self-reported physical activity}

Review: Interventions for promoting physical activity

Comparison: 0 I Pooled effects

Outcome: 0 I Studies with continuous data for self-reported physical activity

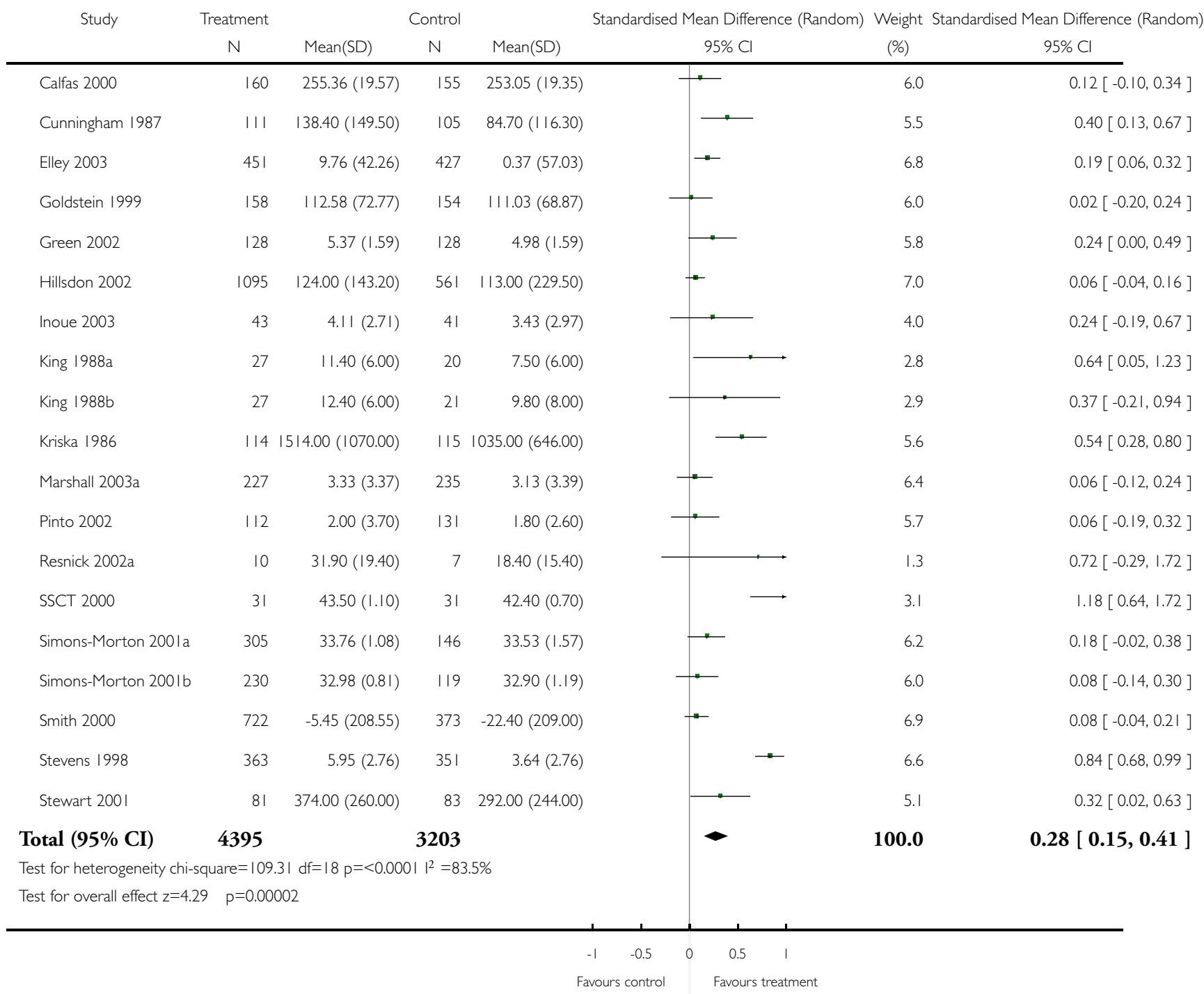


Analysis 01.02. Comparison 01 Pooled effects, Outcome 02 Studies with dichotomous data for self-reported physical activity

Review: Interventions for promoting physical activity

Comparison: 01 Pooled effects

Outcome: 02 Studies with dichotomous data for self-reported physical activity

\begin{tabular}{|c|c|c|c|c|c|}
\hline Study & $\begin{array}{c}\text { Treatment } \\
\mathrm{n} / \mathrm{N}\end{array}$ & $\begin{array}{c}\text { Control } \\
n / N\end{array}$ & $\begin{array}{c}\text { Odds Ratio (Random) } \\
95 \% \mathrm{Cl}\end{array}$ & $\begin{array}{c}\text { Weight } \\
(\%)\end{array}$ & $\begin{array}{c}\text { Odds Ratio (Random) } \\
95 \% \mathrm{Cl}\end{array}$ \\
\hline Dubbert 2002 & $50 / 121$ & $14 / 60$ & $\longrightarrow$ & 8.2 & $2.31[1.15,4.66]$ \\
\hline Harland 1999 & $92 / 351$ & $21 / 91$ & & 10.9 & $1.18[0.69,2.04]$ \\
\hline Lamb 2002 & $40 / 89$ & $34 / 97$ & 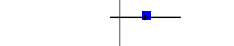 & 10.0 & $1.51[0.84,2.73]$ \\
\hline Lombard 1995 & $32 / 108$ & $1 / 27$ & 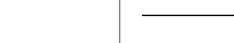 & 1.5 & $10.95[1.42,84.15]$ \\
\hline Marshall 2004 & $115 / 316$ & | |4/358 & $\rightarrow$ & 16.0 & $1.22[0.89,1.69]$ \\
\hline Norris 2000 & $212 / 450$ & $192 / 362$ & $\rightarrow$ & 17.1 & $0.79[0.60,1.04]$ \\
\hline Pinto 2002 & $22 / 110$ & $22 / 131$ & - & 8.9 & $1.24[0.64,2.38]$ \\
\hline Reid 1979 & $24 / 77$ & $10 / 47$ & $=$ & 6.4 & $1.68[0.72,3.92]$ \\
\hline Simons-Morton $200 \mathrm{Ia}$ & $74 / 305$ & $24 / 146$ & $\longrightarrow$ & 11.5 & $1.63[0.98,2.71]$ \\
\hline Simons-Morton $200 \mathrm{lb}$ & $40 / 230$ & $17 / 119$ & $\rightarrow$ & 9.5 & $1.26[0.68,2.34]$ \\
\hline Total $(95 \%$ CI) & 2157 & 1438 & $<$ & 100.0 & $1.33[1.03,1.72]$ \\
\hline \multicolumn{6}{|c|}{ Total events: 70I (Treatment), 449 (Control) } \\
\hline \multicolumn{6}{|c|}{ Test for heterogeneity chi-square $=19.32 \mathrm{df}=9 \mathrm{p}=0.02 \mathrm{I}^{2}=53.4 \%$} \\
\hline Test for overall effect $z=2$. & & & & & \\
\hline
\end{tabular}

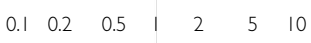

Favours control Favours treatment 
Analysis 01.03. Comparison 0I Pooled effects, Outcome 03 Studies with continuous data for cardiorespiratory fitness

Review: Interventions for promoting physical activity

Comparison: 0 I Pooled effects

Outcome: 03 Studies with continuous data for cardio-respiratory fitness

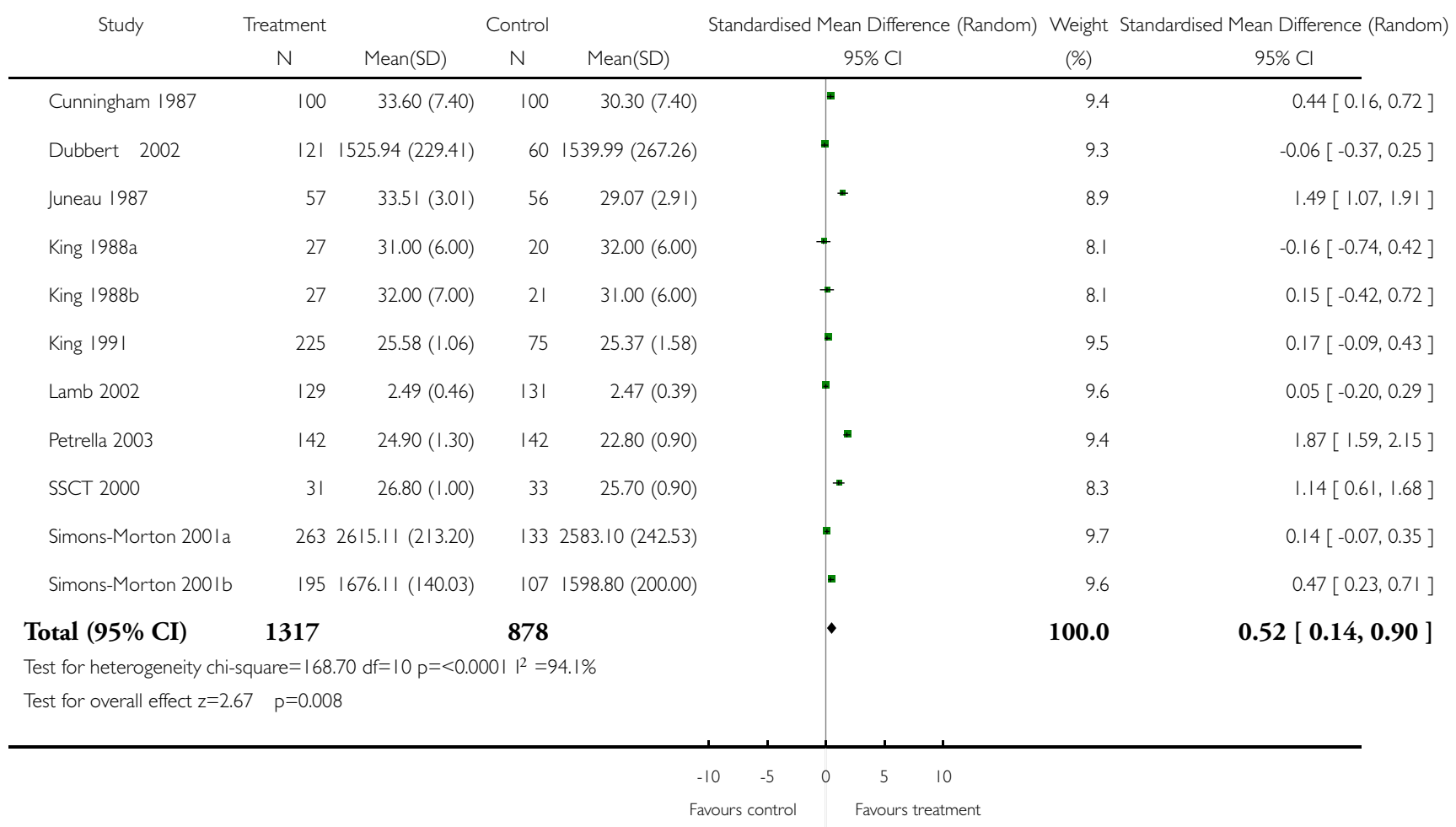




\section{Analysis 02.01. Comparison 02 Sensitivity anaylsis, Outcome 01 Study quality - continuous data for self-}

reported physical activity

Review: Interventions for promoting physical activity

Comparison: 02 Sensitivity anaylsis

Outcome: 0 I Study quality - continuous data for self-reported physical activity

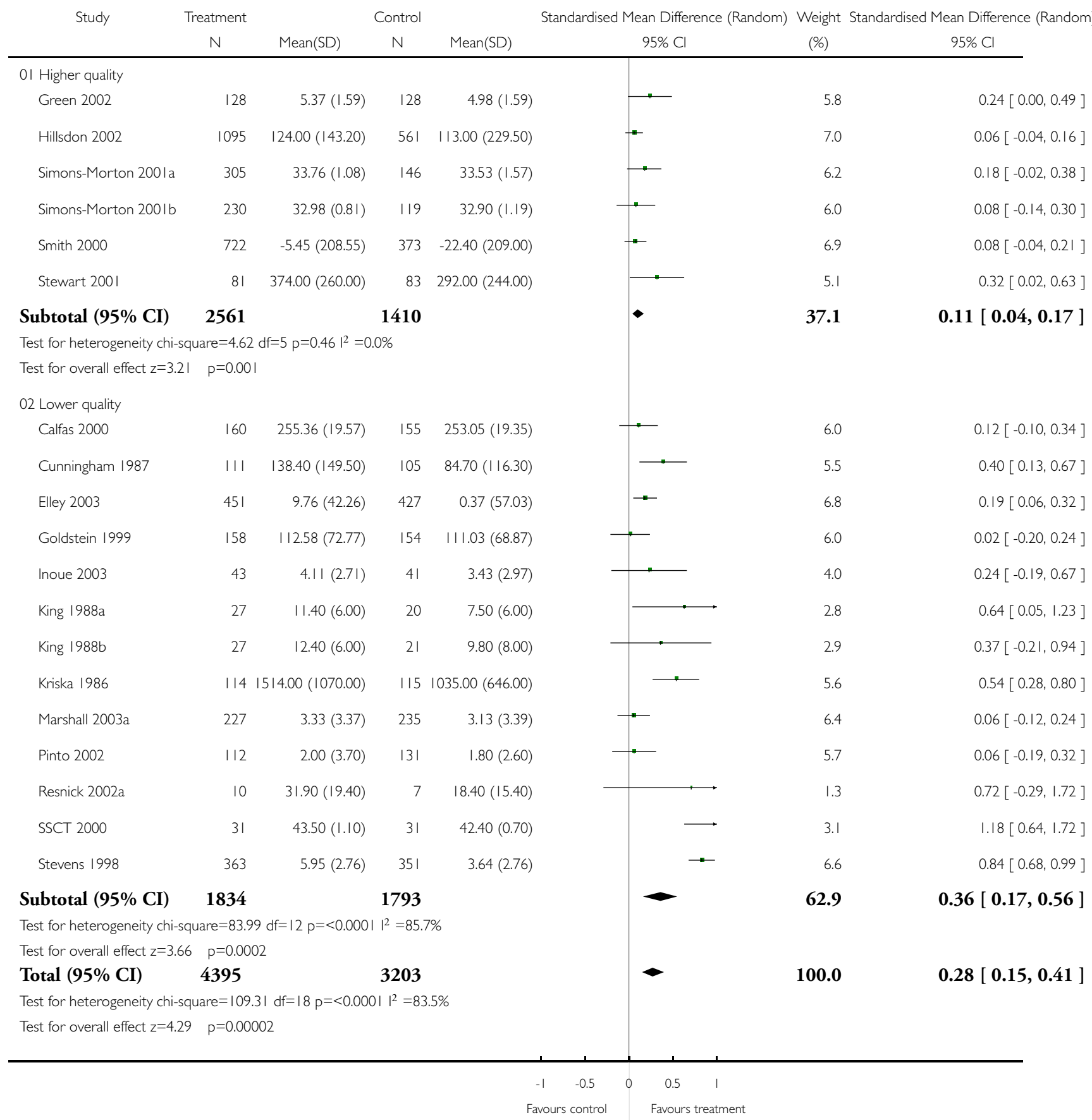

Interventions for promoting physical activity (Review) 
Analysis 02.02. Comparison 02 Sensitivity anaylsis, Outcome 02 Study quality - dichotomous data for selfreported physcial activity

Review: Interventions for promoting physical activity

Comparison: 02 Sensitivity anaylsis

Outcome: 02 Study quality - dichotomous data for self-reported physcial activity

\begin{tabular}{|c|c|c|c|c|c|}
\hline Study & $\begin{array}{l}\text { Treatment } \\
n / N\end{array}$ & $\begin{array}{l}\text { Control } \\
\mathrm{n} / \mathrm{N}\end{array}$ & $\begin{array}{l}\text { Odds Ratio (Random) } \\
995 \% \mathrm{Cl}\end{array}$ & $\begin{array}{c}\text { Weight } \\
(\%)\end{array}$ & $\begin{array}{l}\text { Odds Ratio (Random) } \\
995 \% \mathrm{Cl}\end{array}$ \\
\hline \multicolumn{6}{|l|}{01 Higher quality } \\
\hline Lamb 2002 & $40 / 89$ & $34 / 97$ & $\longrightarrow$ & 10.0 & $|.5|[0.84,2.73]$ \\
\hline Simons-Morton $200 \mathrm{Ia}$ & $74 / 305$ & $24 / 146$ & $\longrightarrow$ & 11.5 & $1.63[0.98,2.71]$ \\
\hline Simons-Morton $200 \mathrm{lb}$ & $40 / 230$ & $17 / 119$ & $\longrightarrow$ & 9.5 & $1.26[0.68,2.34]$ \\
\hline Subtotal $(95 \%$ CI $)$ & 624 & 362 & & 31.1 & $1.48[1.07,2.06]$ \\
\hline \multicolumn{6}{|c|}{ Total events: I54 (Treatment), 75 (Control) } \\
\hline \multicolumn{6}{|c|}{ Test for heterogeneity chi-square $=0.39 \mathrm{df}=2 \mathrm{p}=0.82 \mathrm{I}^{2}=0.0 \%$} \\
\hline \multicolumn{6}{|c|}{ Test for overall effect $z=2.36 \quad p=0.02$} \\
\hline \multicolumn{6}{|l|}{02 Lower quality } \\
\hline Dubbert 2002 & $50 / 121$ & $14 / 60$ & & 8.2 & $2.31[1.15,4.66]$ \\
\hline Harland 1999 & $92 / 351$ & $21 / 91$ & $\longrightarrow$ & 10.9 & $1.18[0.69,2.04]$ \\
\hline Lombard 1995 & $32 / 108$ & $1 / 27$ & + & 1.5 & $10.95[1.42,84.15]$ \\
\hline Marshall 2004 & $115 / 316$ & $1 / 4 / 358$ & $\mp$ & 16.0 & $1.22[0.89,1.69]$ \\
\hline Norris 2000 & $212 / 450$ & 192/362 & $\rightarrow$ & 17.1 & $0.79[0.60,1.04]$ \\
\hline Pinto 2002 & $22 / 110$ & $22 / 131$ & $\longrightarrow$ & 8.9 & $1.24[0.64,2.38]$ \\
\hline Reid 1979 & $24 / 77$ & $10 / 47$ & - & 6.4 & $1.68[0.72,3.92]$ \\
\hline Subtotal (95\% CI) & 1533 & 1076 & 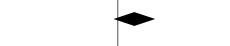 & 68.9 & $1.31[0.93,1.85]$ \\
\hline \multicolumn{6}{|c|}{ Total events: 547 (Treatment), 374 (Control) } \\
\hline \multicolumn{6}{|c|}{ Test for heterogeneity chi-square $=16.43 \mathrm{df}=6 \mathrm{p}=\left.0.0 \mathrm{I}\right|^{2}=63.5 \%$} \\
\hline \multicolumn{6}{|c|}{ Test for overall effect $z=1.52 \quad p=0.1$} \\
\hline Total $(95 \%$ CI $)$ & 2157 & 1438 & $<$ & 100.0 & $1.33[1.03,1.72]$ \\
\hline \multicolumn{6}{|c|}{ Total events: 70 I (Treatment), 449 (Control) } \\
\hline \multicolumn{6}{|c|}{ Test for heterogeneity chi-square $=19.32 \mathrm{df}=9 \mathrm{p}=0.02 \mathrm{I}^{2}=53.4 \%$} \\
\hline Test for overall effect $z=2.19$ & & & & & \\
\hline
\end{tabular}

$\begin{array}{lllllll}0.1 & 0.2 & 0.5 & 1 & 2 & 5 & 10\end{array}$

Favours control Favours treatment 
Analysis 02.03. Comparison 02 Sensitivity anaylsis, Outcome 03 Study quality - continuous data for cardio-

\section{respiratory fitness}

Review: Interventions for promoting physical activity

Comparison: 02 Sensitivity anaylsis

Outcome: 03 Study quality - continuous data for cardio-respiratory fitness

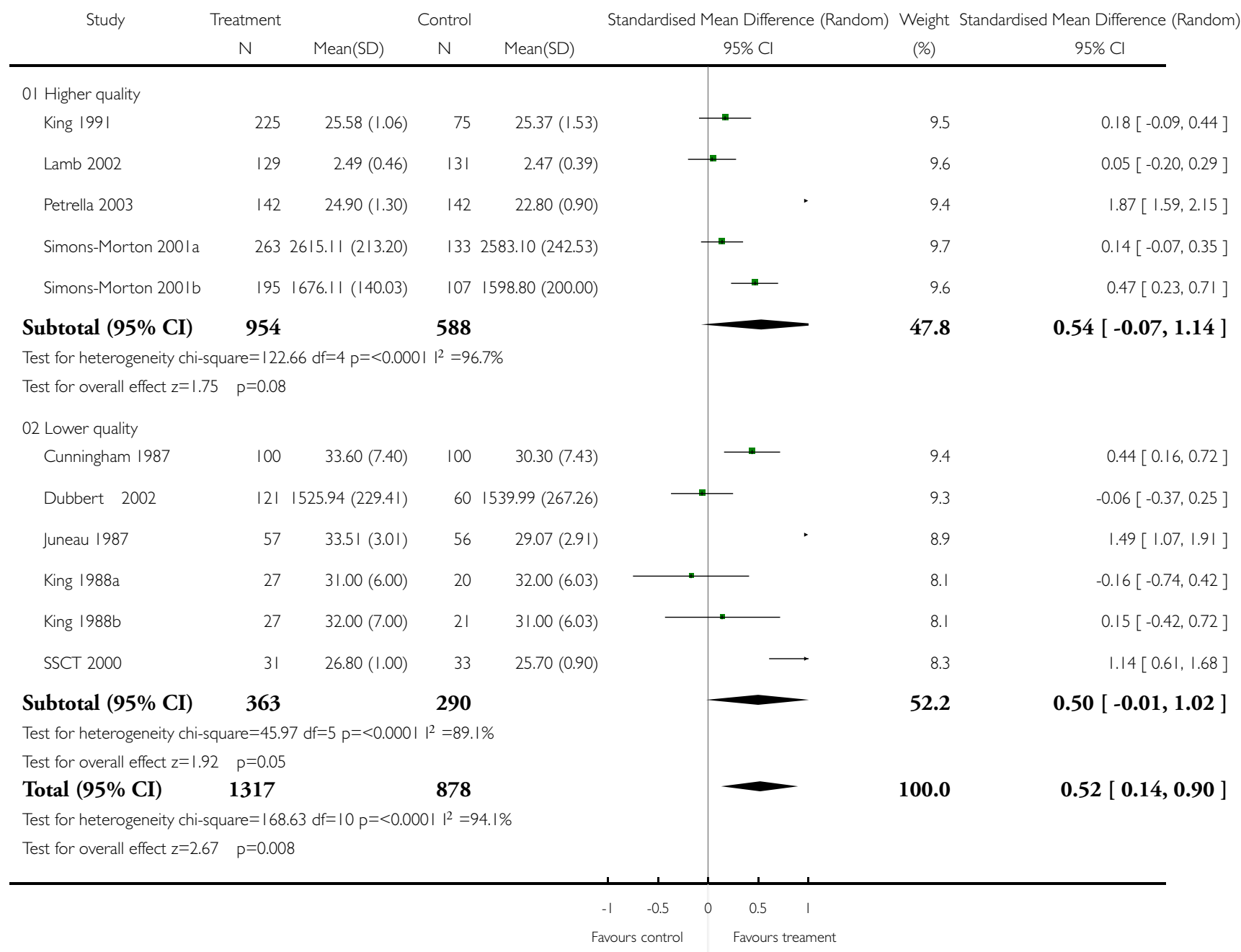




\section{Analysis 03.01. Comparison 03 Sub group analysis, Outcome 01 Nature of direction - self-reported physical activity}

Review: Interventions for promoting physical activity

Comparison: 03 Sub group analysis

Outcome: 01 Nature of direction - self-reported physical activity

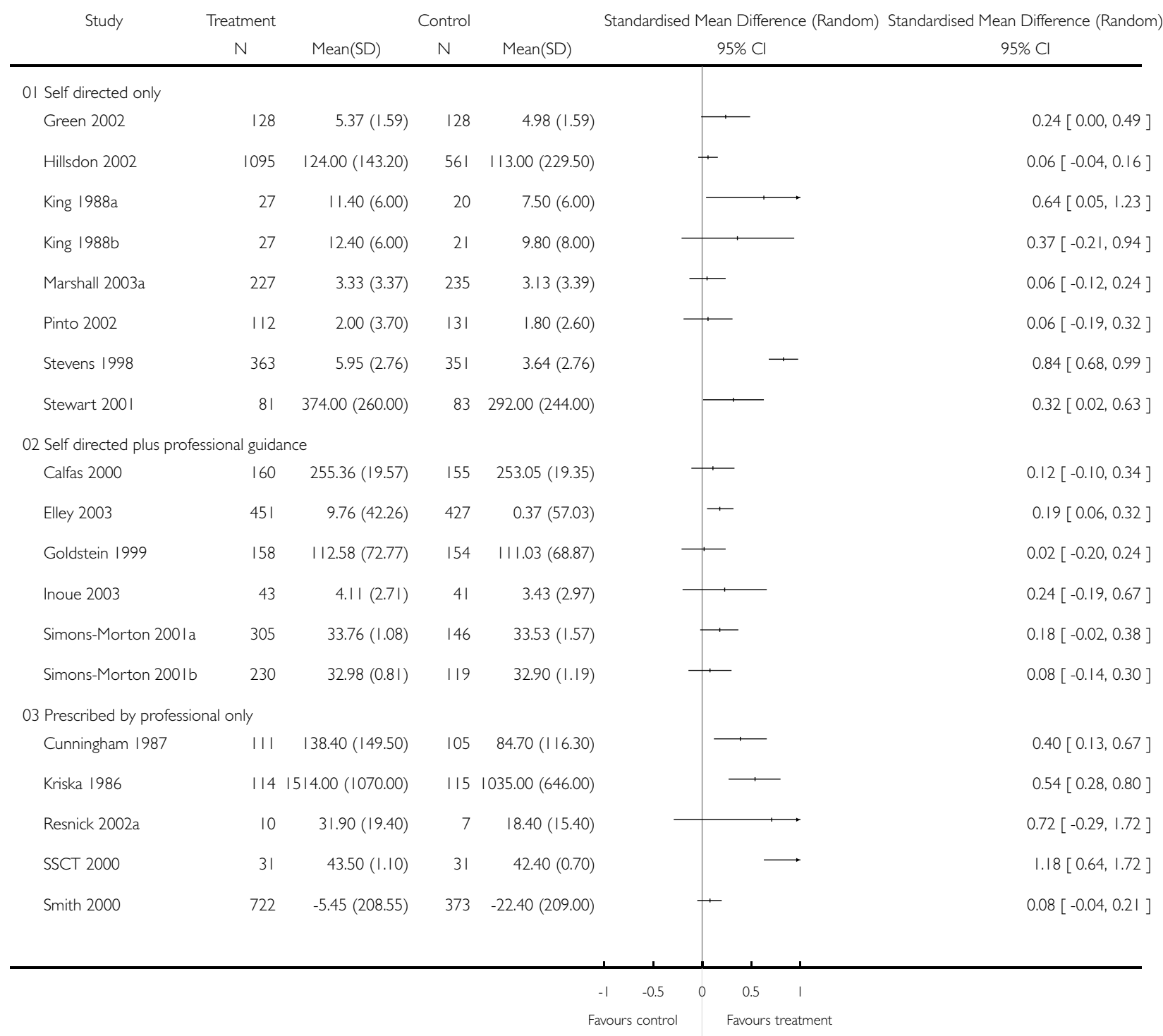




\section{Analysis 03.02. Comparison 03 Sub group analysis, Outcome 02 Nature of direction - cardio-respiratory}

fitness

Review: Interventions for promoting physical activity

Comparison: 03 Sub group analysis

Outcome: 02 Nature of direction - cardio-respiratory fitness

Study

Treatment

Control

Standardised Mean Difference (Random) Standardised Mean Difference (Random)

N

$\operatorname{Mean}(\mathrm{SD})$

N Mean(SD) $95 \% \mathrm{Cl}$ 95\% Cl

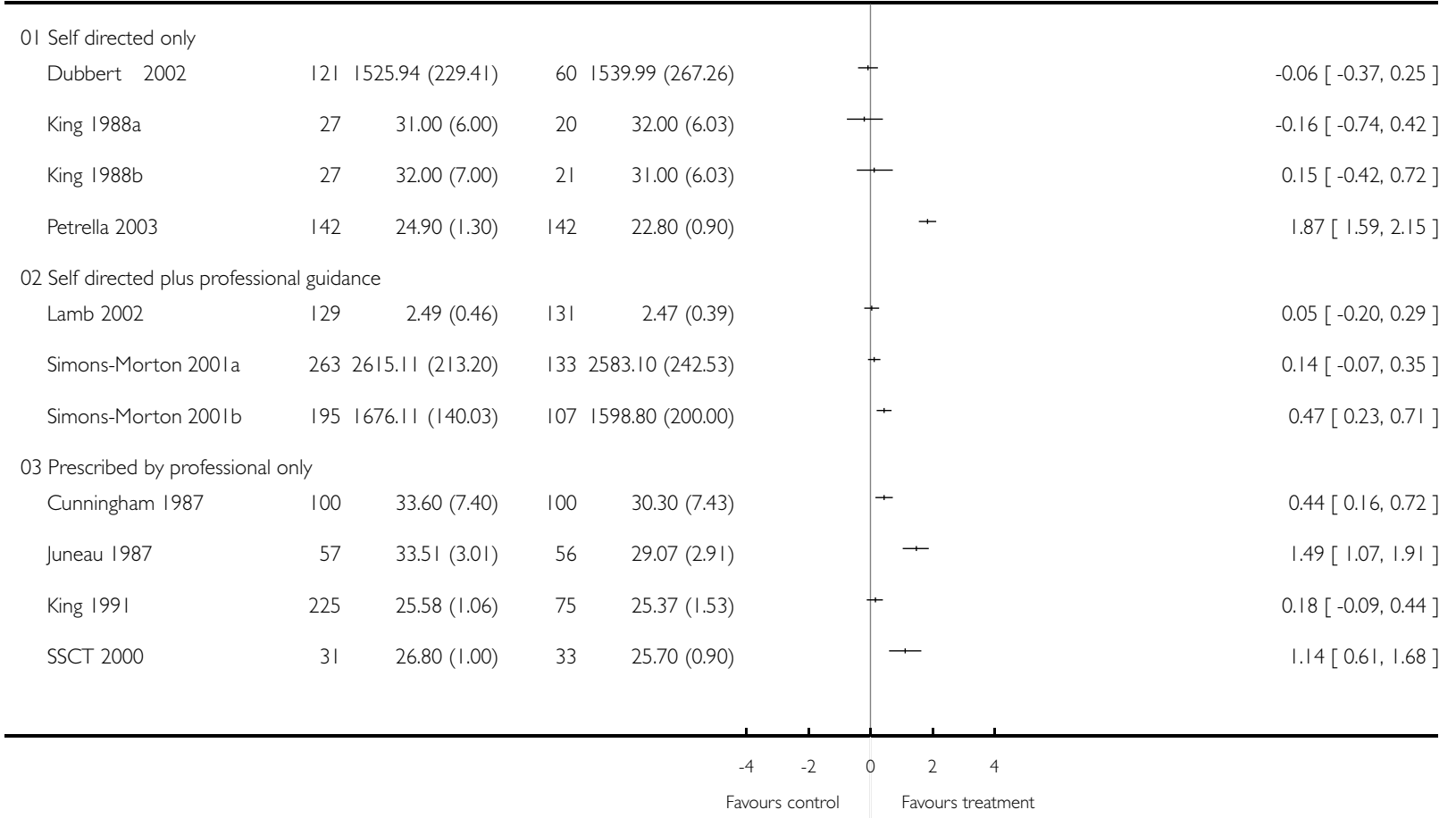


Analysis 03.03. Comparison 03 Sub group analysis, Outcome 03 Frequency of intervention occasions - selfreported physical activity

Review: Interventions for promoting physical activity

Comparison: 03 Sub group analysis

Outcome: 03 Frequency of intervention occasions - self-reported physical activity

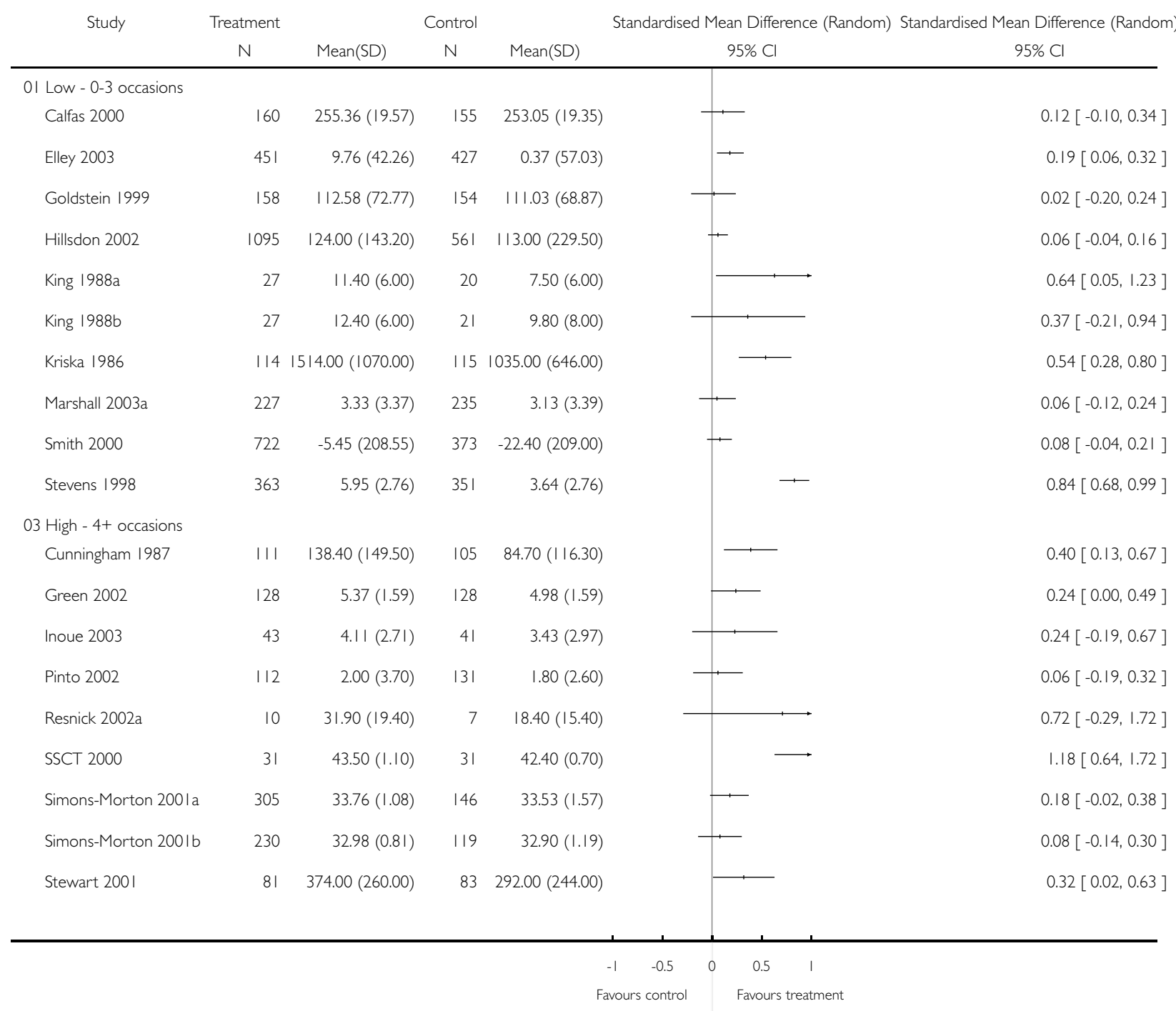


Analysis 03.04. Comparison 03 Sub group analysis, Outcome 04 Frequency of intervention occasions dichotomous data

Review: Interventions for promoting physical activity

Comparison: 03 Sub group analysis

Outcome: 04 Frequency of intervention occasions - dichotomous data

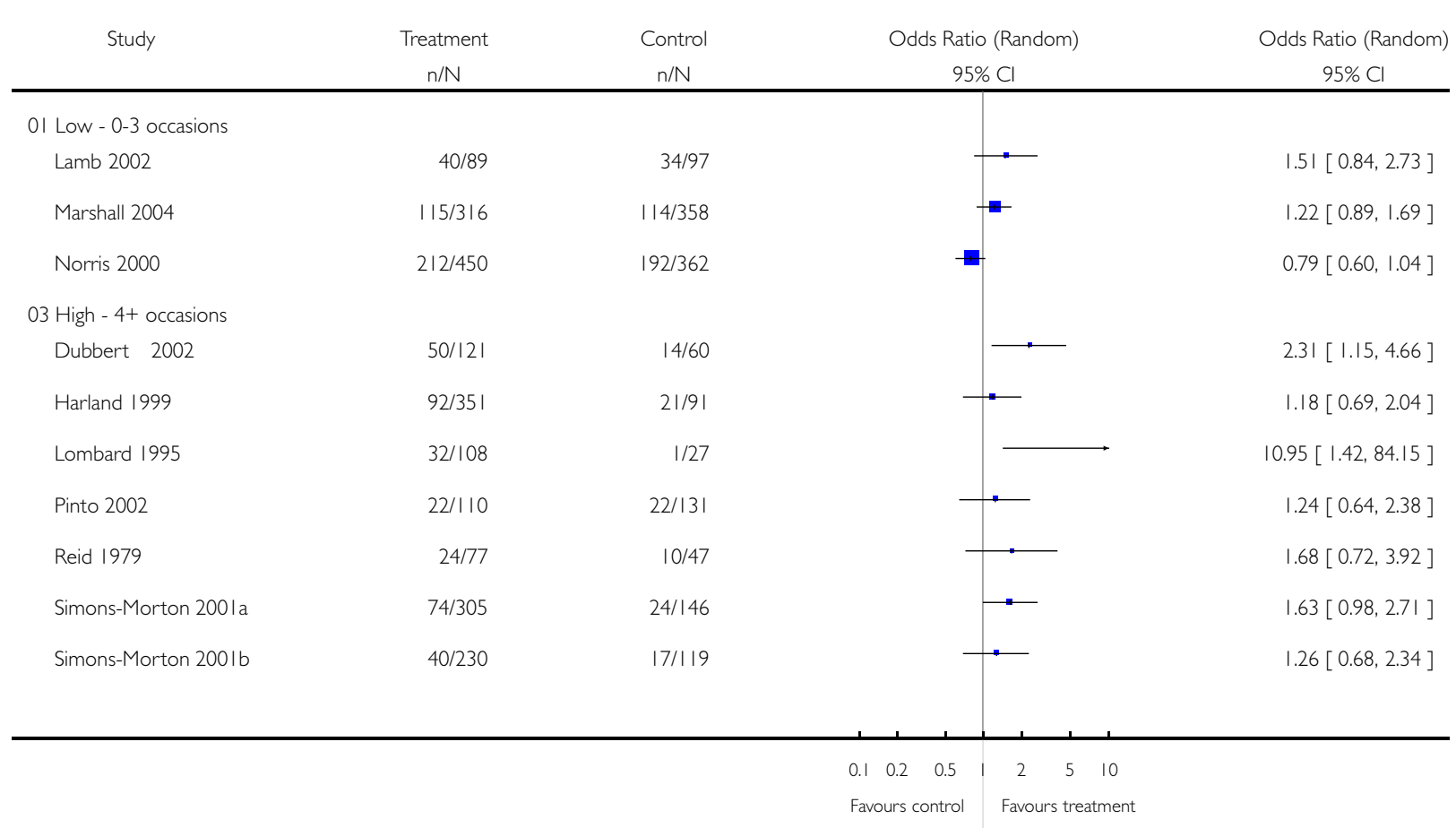


Analysis 03.05. Comparison 03 Sub group analysis, Outcome 05 Frequency of intervention occasions - cardiorespiratory fitness

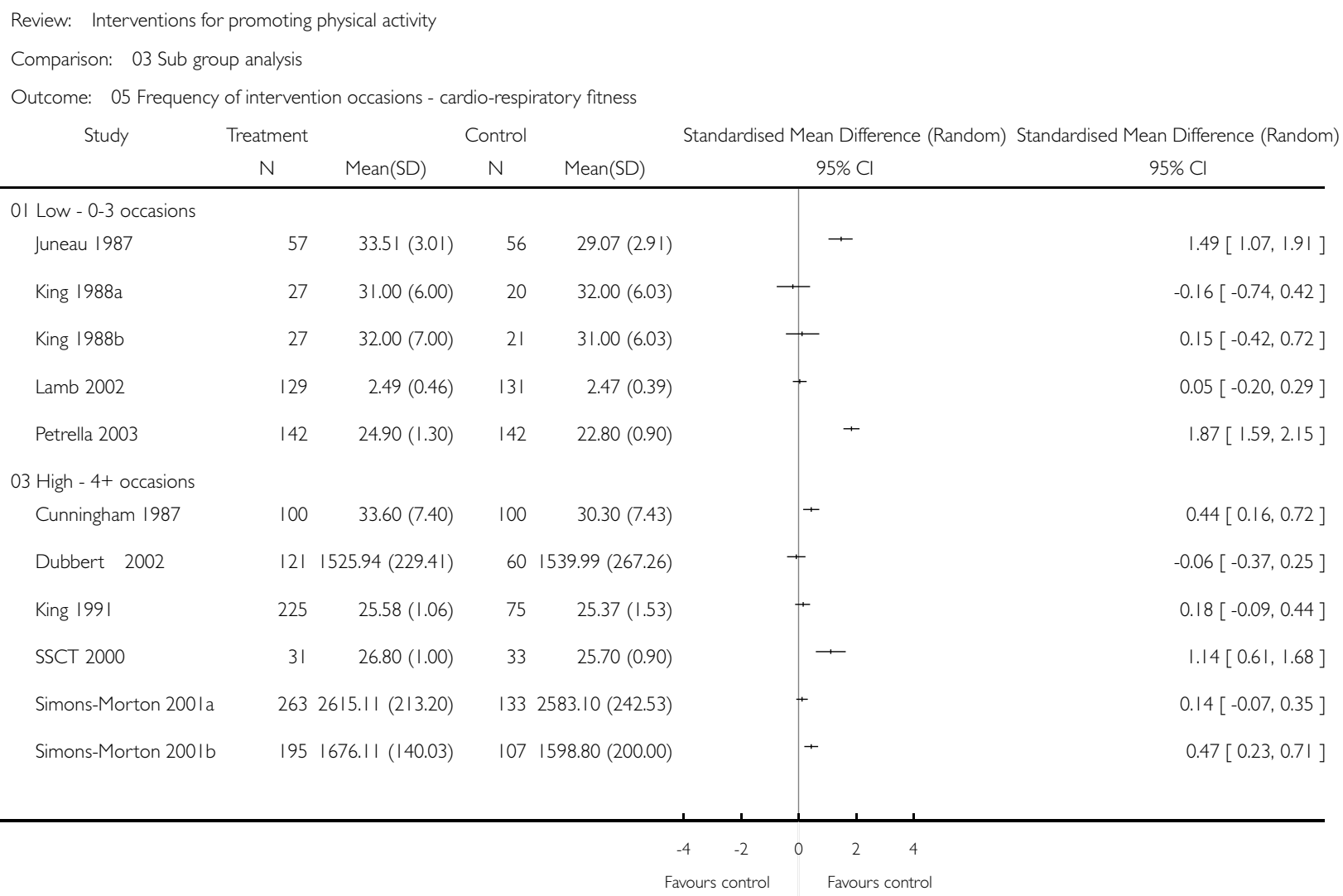




\section{Analysis 03.06. Comparison 03 Sub group analysis, Outcome 06 Frequency of follow-up - self-reported}

physical activity

Review: Interventions for promoting physical activity

Comparison: 03 Sub group analysis

Outcome: 06 Frequency of follow-up - self-reported physical activity

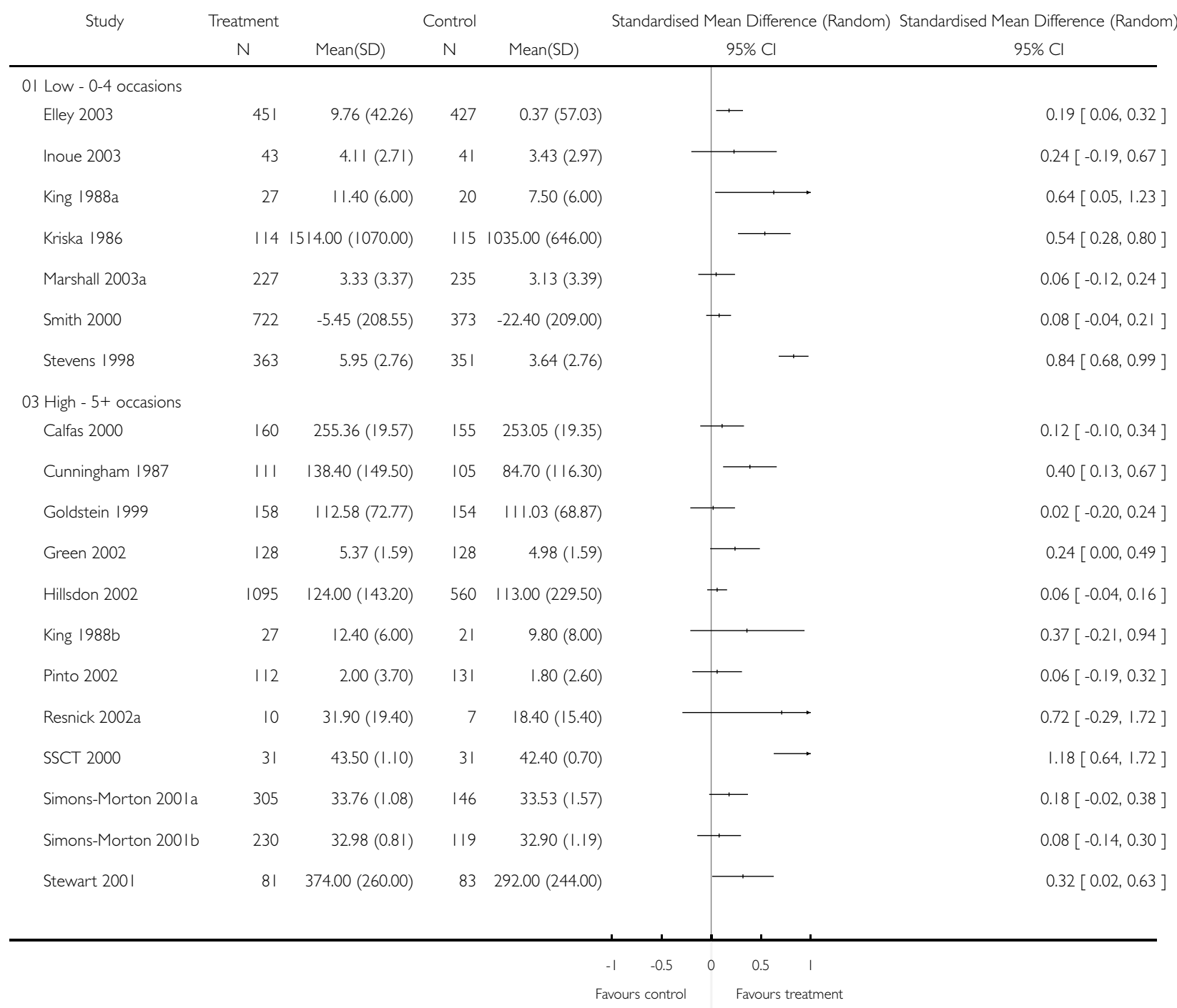




\section{Analysis 03.07. Comparison 03 Sub group analysis, Outcome 07 Frequency of follow-up - cardio-respiratory}

fitness

Review: Interventions for promoting physical activity

Comparison: 03 Sub group analysis

Outcome: 07 Frequency of follow-up - cardio-respiratory fitness

\begin{tabular}{|c|c|c|c|c|c|c|}
\hline \multirow[t]{2}{*}{ Study } & Treatment & & Contr & & Standardised Mean Difference (Random) & Standardised Mean Difference (Random) \\
\hline & N & Mean(SD) & $\mathrm{N}$ & Mean(SD) & $95 \% \mathrm{Cl}$ & $95 \% \mathrm{Cl}$ \\
\hline
\end{tabular}

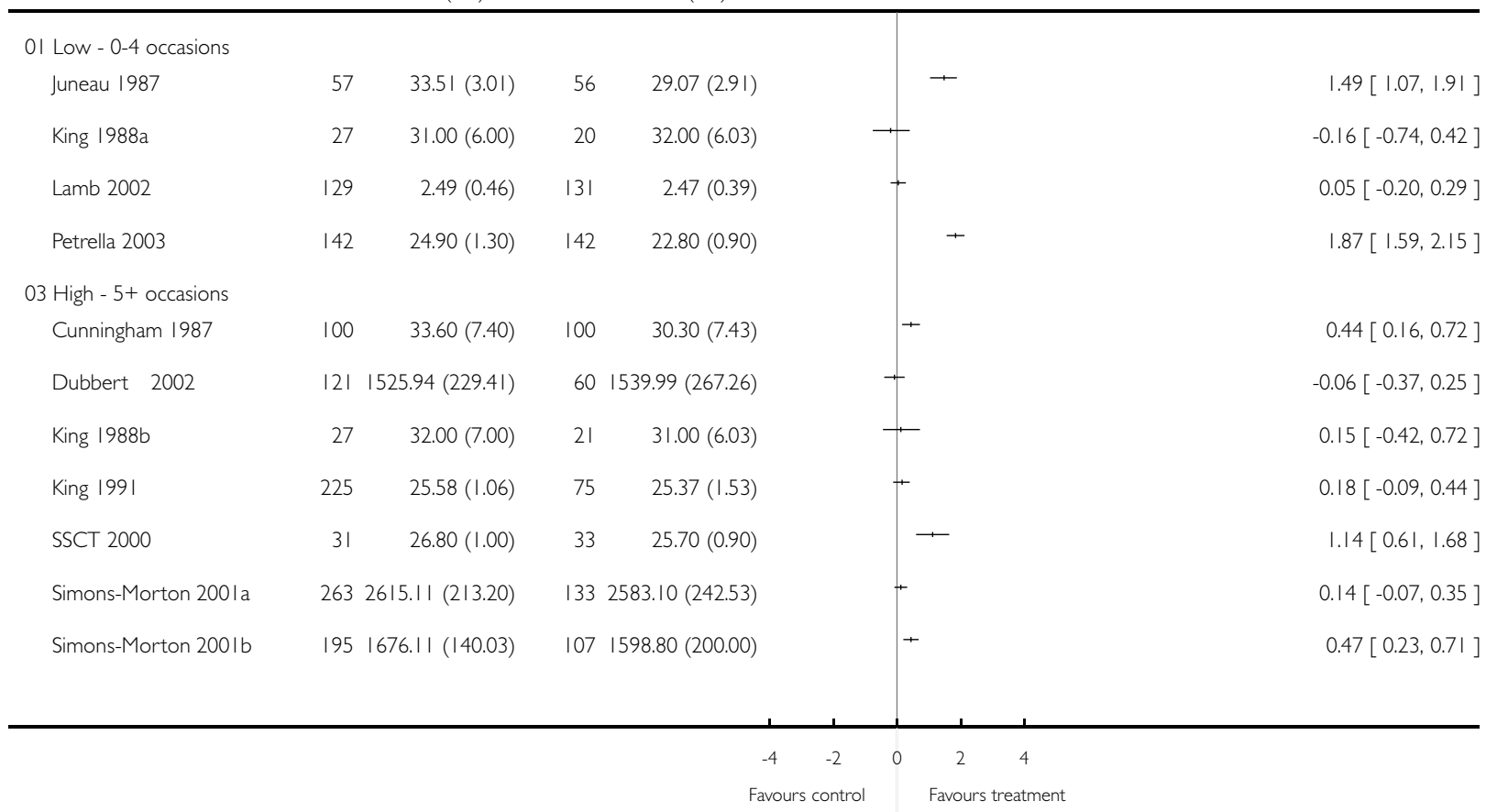


Analysis 03.08. Comparison 03 Sub group analysis, Outcome 08 Frequency of follow-up - dichotomous data Review: Interventions for promoting physical activity

Comparison: 03 Sub group analysis

Outcome: 08 Frequency of follow-up - dichotomous data

\begin{tabular}{|c|c|c|c|c|}
\hline Study & $\begin{array}{c}\text { Treatment } \\
\mathrm{n} / \mathrm{N}\end{array}$ & $\begin{array}{c}\text { Control } \\
\mathrm{n} / \mathrm{N}\end{array}$ & $\begin{array}{l}\text { Odds Ratio (Random) } \\
\qquad 95 \% \mathrm{Cl}\end{array}$ & $\begin{array}{c}\text { Odds Ratio (Random) } \\
95 \% \mathrm{Cl} \\
\end{array}$ \\
\hline \multicolumn{5}{|l|}{ 0I Low - 0-4 occasions } \\
\hline Harland 1999 & $92 / 351$ & $21 / 91$ & - & $1.18[0.69,2.04]$ \\
\hline Lamb 2002 & $40 / 89$ & $34 / 97$ & $\longrightarrow$ & $1.51[0.84,2.73]$ \\
\hline Marshall 2004 & $115 / 316$ & $114 / 358$ & - & $1.22[0.89,1.69]$ \\
\hline Reid 1979 & $24 / 77$ & $10 / 47$ & t. & $1.68[0.72,3.92]$ \\
\hline \multicolumn{5}{|l|}{03 High - $5+$ occasions } \\
\hline Dubbert 2002 & $50 / 121$ & $14 / 60$ & 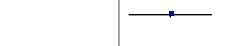 & $2.31[1.15,4.66]$ \\
\hline Lombard 1995 & $32 / 108$ & $1 / 27$ & & $10.95[1.42,84.15]$ \\
\hline Norris 2000 & $212 / 450$ & $192 / 362$ & 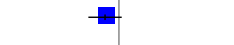 & $0.79[0.60,1.04]$ \\
\hline Pinto 2002 & $22 / 110$ & $22 / 131$ & + & $1.24[0.64,2.38]$ \\
\hline Simons-Morton $200 \mathrm{Ia}$ & $74 / 305$ & $24 / 146$ & 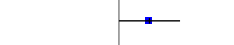 & $1.63[0.98,2.71]$ \\
\hline Simons-Morton $200 \mathrm{lb}$ & $40 / 230$ & $17 / 119$ & - & $1.26[0.68,2.34]$ \\
\hline
\end{tabular}




\section{Analysis 03.09. Comparison 03 Sub group analysis, Outcome 09 Degree of supervision - self-reported physical activity}

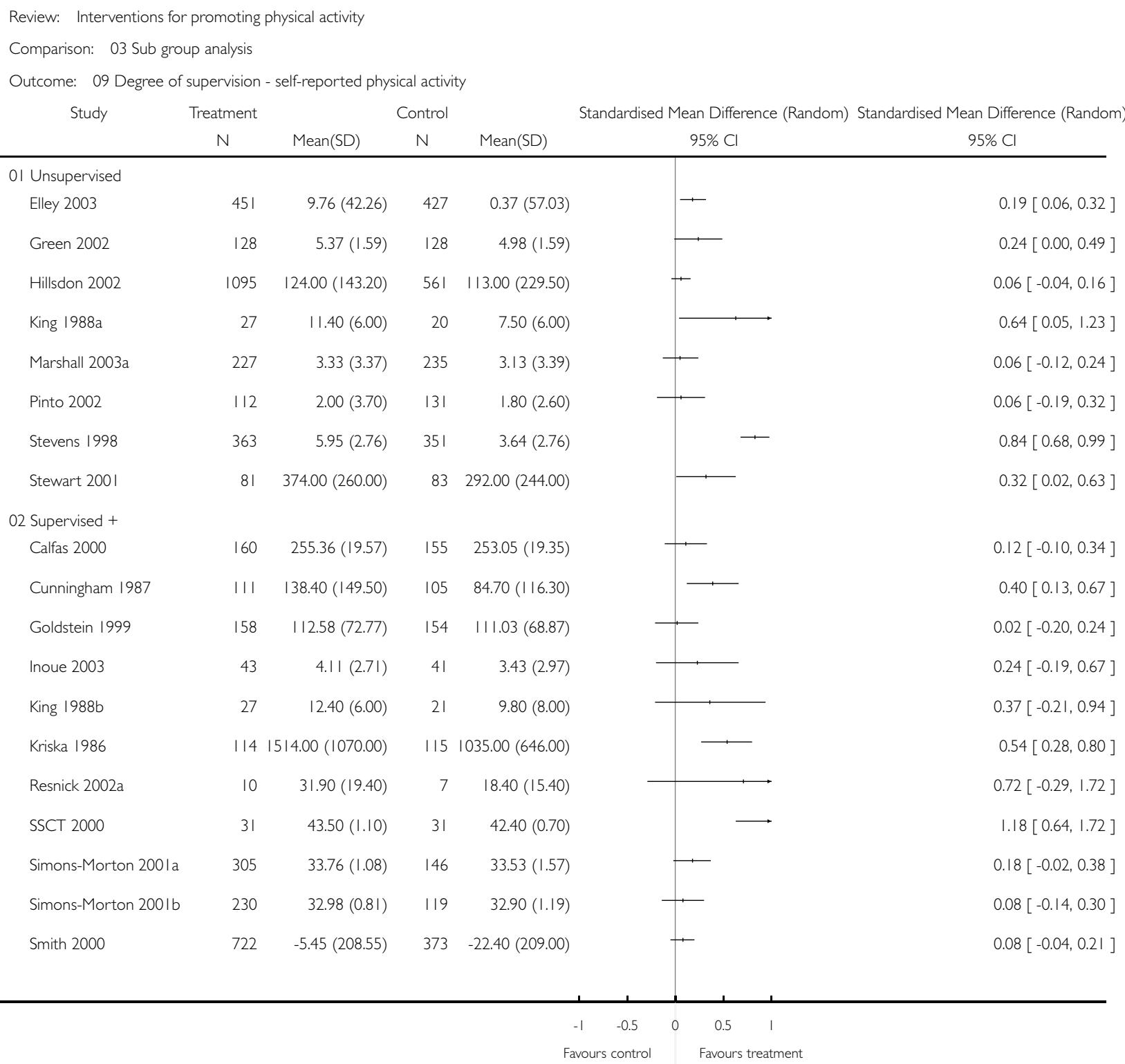




\section{Analysis 03.10. Comparison 03 Sub group analysis, Outcome 10 Degree of supervison - cardio-respiratory}

fitness

Review: Interventions for promoting physical activity

Comparison: 03 Sub group analysis

Outcome: 10 Degree of supervison-cardio-respiratory fitness

\begin{tabular}{cccccc} 
Study & Control & & \multicolumn{2}{c}{ Standardised Mean Difference (Random) Standardised Mean Difference (Random) } \\
$\mathrm{N}$ & Mean(SD) & $\mathrm{N}$ & Mean(SD) & $95 \% \mathrm{Cl}$ & $95 \% \mathrm{Cl}$ \\
\hline
\end{tabular}

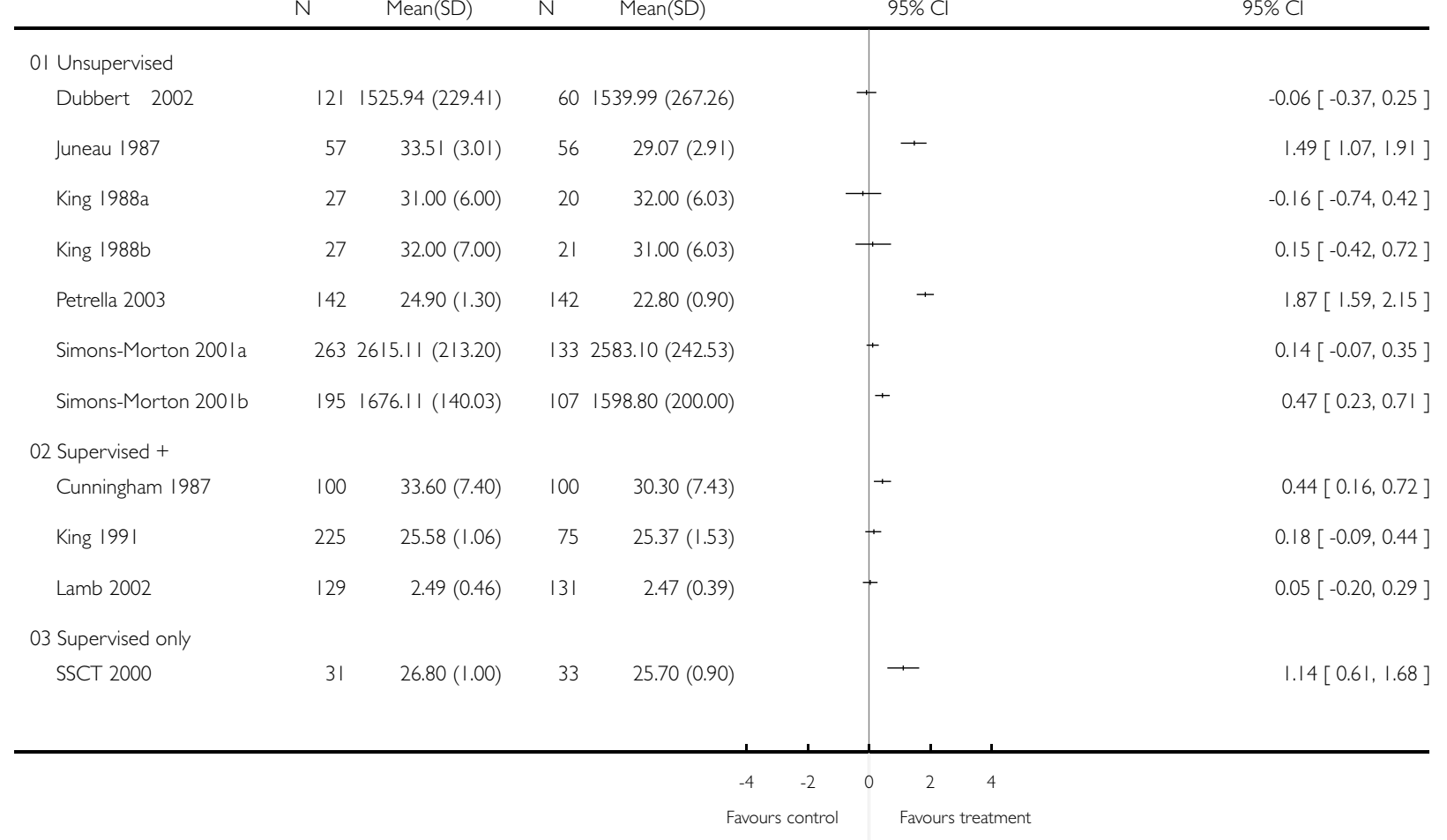

